\title{
UTILIZAÇÃO DE FOTOGRAFIAS AÉREAS EM TRÊS ESCALAS NO ESTUDO DE REDES DE DRENAGEM EM DIFERENTES UNIDADES DE SOLO
}

\author{
FRANCISCO DE PAULA NOGUEIRA
}

Orientador: GERALDO VICTORINO DE FRANCA

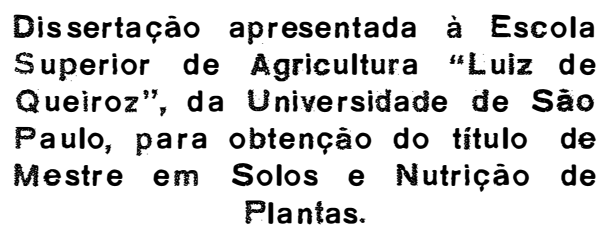

PIRACICABA

Estado de Sào Paulo - Brasil

Junho, 1979 
ii.

A Maria José e Nelson, pela vida de exemplos, A Verena e Constanza, razões de esperanga, oferego.

A sandra, pelo incentivo, amizade e amor, dedico. 
Ao Professor Dr. Geraldo Victorino de Franga, pela valiosa orientagão no desenvolvimento deste trabalho;

Ao Pesquisador Cientifico Jorge Vicente Chiari$n i$, por todas as facilidades e oportunidades concedidas na realizacão deste trabalho;

Ao Pesquisador Cientifico Archimedes Perez FiIho, pela solicitude constante na execucão deste trabalho;

Ao Professor Dr. Humberto de Campos, pela orientacão na anälise estatistica;

Ao Instituto Agronômico, pelas facilidades oferecidas durante a realizacão do Curso e na elaboragão deste trabalho;

A Escola Superior de Agricultura "Luiz de Queiroz", com deferência especial aos professores do Curso de Pós Graduação de Solos e Nurrisão de Plantas, pela oportunidade e facilidades oferecidas para a realizacão deste Curso;

A Girlene Francisco de Souza, pela dedicagão no trabalho de datilografia;

A Nicia Marcondes Zingra, pelo esmero na confeção das figuras;

Aos demais funcionários da segão de Fotointerpretacão do Instituto Agronômico e a todos que direta ou indiretamente colaboraram na realizasão deste trabalho. 
INDICE

Pãgina

RESUMO

1. INTRODUÇÃO

2. REVISÃO DE LITERATURE $\ldots \ldots \ldots \ldots \ldots \ldots \ldots \ldots \ldots \ldots \ldots \ldots \ldots \ldots$

2.1. Fotografias aéreas no estuảo de solos ........

2.2. Caracteristicas das redes de drenagem e sua significância pedológica

3. MATERIAL E METODOS

3.1. Localização geogrä́fica das amostras ........ 16

3.2 . Geologia ......................... 20

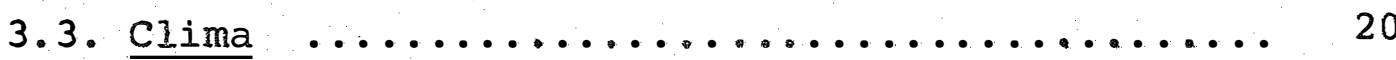

3.4. Solos nas áreas amostradas ............. 24

3.5. Material Eotográfico .................. 34

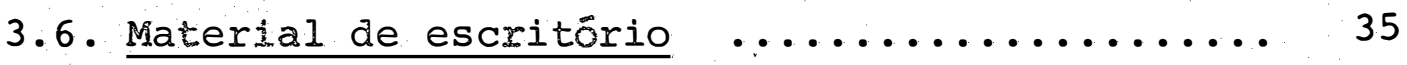

3.7. Seleção das äreas de estudo ............... 35

3.8. Obtenção dos mapas de drenagem ........... 36

3.9. Caracteristicas analisadas dos padrões de dre-

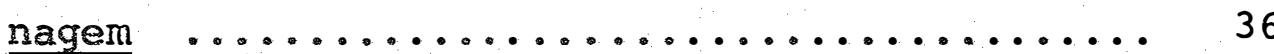

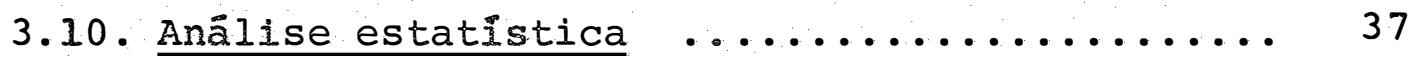

4. RESULTADOS E DISCUSSÃO ..................... 40

4.1. Interpretą̧ão das fotografias aéreas ....... 40

4.2. Caracteristicas dimensionais nas amostras ... 40

4.3. Indices de drenagem .................. 45

4.3.1. Frequência de rios ............... 45

4.3.2. Razão de textura ................ 48

4.3.3. Densidade de drenagem ............. 51

4.3.4. Comprimento médio dos canais de drenagem superficial 
4.4. Textura topográfica .................

4.5. Caracteristicas descritivas do padrão de dre-

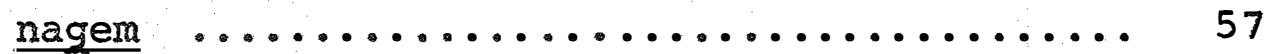

4.6. Sugestões para novas pesquisas .......... 60

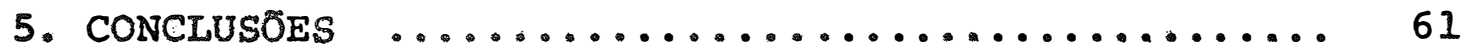

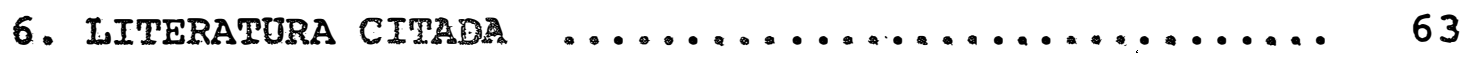

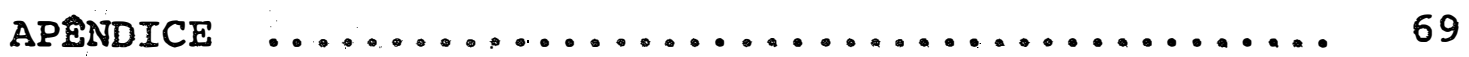


$v i$

\section{LISTA DE QUADROS}

Quadro

Titulo

Pägina

1 Cronogeologia do substrato nos locais das amostras

2 Unidades pedolögicas, localização municipal e variação de altitude das äreas amostradas ...

3 Nünero de canais de drensgem superficial nas amostras circulares, nas três escalas fotográficas

4 Comprimento total dos canais de drenagem superficial, em quilômetros, nas amostras circulares nas três escalas fotogräficas

5 Frequência de rios nas amostras circulares, nas três escalas fotogråricas

6 Resultados do teste de Kruskl-hallis envolvendo as escalas fotogräficas $\left(E_{1}, E_{2}, E_{3}\right)$ e as referências de solo $\left(S_{1}, S_{2}, S_{3}, S_{4}, S_{5}\right)$ e das comparações mültiplas com diferença significa tiva até o nivel de $10 \%$ para o Indice frequência de rios

7 Razão de textura nas amostras circulares, nas três escalas fotogrä́icas

8 Resultados do teste de Kruskal-Waljis envolvendo as escalas fotogräincas $\left(E_{1}, E_{2}, E_{3}\right)$ e as referências de solo $\left(S_{1}, S_{2}, S_{3}, S_{A^{*}}, S_{5}\right)$ e das comparaçōes müliplas com diferença significativa atê o nivel de $1 \%$ para o Indice razão de textura 
vii.

Quadro

TItulo

Página

9 Densidade de drenagem nas amostras circulares, nas três escalas fotogräficaș $\ldots \ldots \ldots \ldots \ldots$

10 Resultados do teste de Rruskal-Wallis envolvendo as escalas fotogråxicas $\left(E_{1}, E_{2}, E_{3}\right)$ e as referências de solo $\left(s_{1}, s_{2}, s_{3}, s_{4}, s_{5}\right)$ e das comparações multiplas com diferença significativa atê o mivel de $10 \%$ para o Indice densidade de drenagem $\quad \ldots \ldots \ldots \ldots \ldots \ldots \ldots \ldots \ldots$

11 Comprimento meado dos camais de drenagem superficial, em guilônetros, nas amostras circulares nas três escalass fotogräricas $\quad \ldots \ldots \ldots \ldots \ldots$

12 Resultados do teste de Kruskal-Wallis envolvendo as escalas fotogräficas $\left(E_{1}, E_{2}, E_{3}\right)$ e as referências de solo $\left(S_{1}, S_{2}, S_{3}, S_{4}, S_{5}\right)$ e das comparações mỉltiplas com diferença significativa até o nivel de loz para o Indice comprimento medio dos carais de drenagem superficial

13 Classes de textura topogrefica nas amostras clrculares, nas três escalas fotogräficas

14 Caracteristicas descritivas do padrão de drenagem dos solos estudados 
viii.

\section{IISTA DE FIGURAS}

Figura

TItulo

Pägina

1 Localização geogråfica e unidades de solo das amostras 1,2 e 3

2 Localização geogrårica e unidades de solo das amostras 5,6 e 7

3 Localização geogråfica e unidades de solo das amostras $8,9,10$ e 11

4 Locallzação geogrãica e unidades de solo das amostras $12,13,14$ e $15 \ldots \ldots \ldots \ldots \ldots \ldots$

5 Localização geogråfica e unidades de solo das amostras 16,17 e 18

No apênd1ce:

1 Amostras circulares 1, 2 e 3, representativas da unidade de solo Podzo̊lico Vermelho Amarelo, na escala aprosinada $2: 60.000$

2 Amostras circulares $4,5,6$ e 7, representativas da unidade we solo Podzo̊lico Vermelho Amarelo, na escala aproximada 1:60.000

3 Amostras circulares 8, 9, 10 e 11, representativas da unidade de solo Latossolo Vermelho Amarelo, na escala aproximada $1: 60.000 \ldots . .$.

4 Amostras circulares $12,13,14$ e 15, representativas da unidade de solo Latossolo Vermelho Amarelo, na escala aproximada $1: 60.000$ 
5 Amostras circulares 16,17 e 18, representati vas da unidade de solo Latossolo Roxo, na escala aproximada $1: 60.000$

6 Amostra circular 1, representativa da unidade de solo Podzólico Vermelho Amarelo, na escala aproximada $1: 35.000$

7 Amostra circular 2, representativa da unidade de solo Podzólico Vermelho Amarelo, na escala aproximada $1: 35.000$

8. Amostra circular 3, representativa da unidade de solo Podzólico Vermelho Amarelo, na escala aproximada $1: 35.000$

9 Amostra circular 4, representativa da unidade de solo Podzólico Vermelho Amarelo, na escala aproximada $1: 35.000$

10 Amostra circular 5, representativa da unidade de solo Podzôlico Vermelho Amarelo, na escala aproximada $1: 35.000$

11 Amostra circular 6, representativa da unidade de solo Podzólico Vermelho Amarelo, na escala aproximada $1: 35.000$

12 Amostra circular 7, representativa da unidade de solo Podzólico Vermelho Amarelo, na escala aproximada $1: 35.000$

13 Amostra circular 8, representativa da unidade de solo Iatossolo Vermelho Amarelo, na escala aproximada. $1: 35.000$ 
14 Amostra circular 9, representativa da unidade de solo Latossolo Vermelho Amarelo, na escala aproximada $1: 35.000$

15 Amostra circular 10, representativa da unidade de solo Latossolo Vermelho Amarelo, na escala aproximada $1: 35.000$

16 Amostra circular 11, representativa da unidade de solo Latossolo Vermelho Amarelo, na escala aproximada $1: 35.000$

17 Amostra circular 12, representativa da unidade de solo Latossolo Vermelho Amarelo, na escala aproximada $1: 35.000$

18 Amostra circular 13, representativa da unidade de solo Latossolo Vermelho Amarelo, na escala aproximada $1: 35.000$

19 Amostra circular 14, representativa da unidade de solo Latossolo Vermelho Amarelo, na escala aproximada $1: 35.000$

20 Amostra circular 15, representativa da unidade de solo Latossolo Vermelho Amarelo, na escala aproximada $1: 35.000$

21 Amostra circular 16, representativa da unidade de solo Latossolo Roxo, na escala aproximada $1: 35.000$

22 Amostra circular 17, representativa da unidade de solo Latossolo Roxo, na escala aproximada $1: 35.000$ 
23 Amostra circular 18, representativa da unidade de solo Latossolo Roxo, na escala aproximada $1: 35.000$

24. Amostra circular 1, representativa da unidade de solo Podzólico Vermelho Amarelo, na escala aproximada $1: 25.000$

25 Amostra circular 2, representativa da unidade de solo Podzólico Vermelho Amarelo, na escala aproximada $1: 25.000$

26 Amostra circular 3, representativa da unidade de solo Podzólico Vermelho Amarelo, na escala aproximada $1: 25.000$

27. Amostra circular 4, representativa da unidade de solo Podzólico Vermelho Amarelo, na escala aproximada $1: 25.000$

28 Amostra circular 5, representativa da unidade de solo Podzólico Vermelho Amarelo, na escala aproximada $1: 25.000$

29 Amostra circular 6, representativa da unidade de solo Podzólico Vermelho Amarelo, na escala aproximada $1: 25.000$

30 Amostra circular 7, representativa da unidade de solo Podzólico Vermelho Amarelo, na escala aproximada $1: 25.000$

31 Amostra circular 8, representativa da unidade de solo Iatossolo Vermelho Amarelo, na escala aproximada $1: 25.000$ 
$x i i$.

FIgura

32 Amostra circular 9, representativa da unidade de solo Latossolo Vermelho Amarelo, na escala aproximada $1: 25.000$

33 Amostra circular 10, representativa da unidade de solo Latossolo Vermelho Amarelo, na escala aproximada $1: 25.000$

34 Amostra cixcular 11, representativa da unidade de solo Latossolo Vermelho Amarelo, na escala aproximada $1: 25.000$

35 Amostra circular 12, representativa da unidade de solo Latossolo VermeIho Amarelo, na escala aproximada $1: 25.000$

36 Amostra circular 13, representativa da unidade de solo Latossolo Vermelho Amarelo, na escala aproximada $1: 25.000$

37 Amostra circular 14, representativa da unidade de solo Latossolo Verme hho Amarelo, na escala aproximada $1: 25.000$

38 Amostra circular 15, representativa da unidade de solo Latossolo Vermelho Amarelo, na escala aproximada $1: 25.000 \quad \ldots \ldots \ldots \ldots \ldots \ldots \ldots$

39 Amostra circular 16, representativa da unidade de solo Latossolo Roxo, na escala aproximada $1: 25.000$

40 Amostra circular 17 , representativa da unidade de solo Latossolo Roxo, na escala aproximada $1: 25.000$ 
xiii.

I gura

41 Amostra circular 18, representativa da unidade de solo Latossolo Roxo, na escala aproximada $1: 25.000 \quad \ldots \ldots \ldots \ldots \ldots \ldots \ldots \ldots \ldots \ldots . \ldots . \ldots 110$ 


\section{RESUMO}

Amostras circulares de $10 \mathrm{~km}^{2}$ foram analisadas, através de Imagens aerofotogräfıcas em diferentes escalas $(1: 60.000 ; .1: 35.000 ; 1: 25.000)$. quanto a aspectos da rede de arenagem superficial (padrão de drenagem, frequência de rios, razão de textura, densidade de arenagem e comprimento médio dos canais).

As amostras foram tomadas para representar três unidades de mapeamento pedológico e grupadas em cinco referências. Foram reunidas em duas referências, uma com três e outra com quatro, sete amostras representativas de solo Podzólico Vermelho Amarelo; reuniu-se em duas referências, com quatro amostras cada uma, as representativas de Iratossolo Vermelho Amarelo: outras três, representativas de Latossolo Roxo, foram grupadas em uma ủnica referência.

A frequência de rios e a razão de textura se comportaram semelhantemente em todas as análises, donde se concluiú que 0 uso de qualquer um destes dois Indices, isoladamente, é suflciente para caracterizar redes de drenagem atravês de amostras circulares.

Foi observada diferença significativa entre as escalas extremas na determinação da frequência de rios e da razão de textura em um dos grupamentos de solo Podzólico Vermelho Amarelo. 
As caracteristicas descritivas do padrão de drenagem, nas amostras circulares, mostraram-se adequadas para diferenciar os solos podzólicos dos latossolos.

Diferenciação entre os solos através das caracteristicas da rede de drenagem foi melhor evidenciada pela densidade de drenagem, enquanto que o comprimento médio dos canais foi o indice que apresentou resultados menos significantes.

Dentre as referências de solo, foram diferenciadas significativamente as amostras representativas de um grupamento de solos Podzólico Vermelho Amarelo daquelas dos dois grupamentos de Latossolo Vermelho Amarelo.

As fotografias em escala menor foram as mais efetivas para evidenciar diferenças entre as referências de solo. Recomendou-se o emprego desta escala, por implicar, tambēm, em manuseio de menor quantidade de material fotográfico e permitir melhor percepção de relevo. 
SUMINARY

Comparative studies of drainage network of different soil types carried out on aerial photographs in three scales

Studies of surface drainage network of different soil types were carried out based on aerial photographs representing known pedological mapping units. The prints used were in the approximate scales of 1:60,000, $1: 35,000$, and $1: 25,000$ and were made from vertical aerial photographs taken with panchromatic film.

The samples examined were circular, $10 \mathrm{~km}^{2}$ in area, and served for the determination of drainage pattern, stream frequency, texture ratio, drainage density and mean length of drainageways. Seven samples of "Podzólico Verme1ho Amarelo" and eight of "Latossolo Vermelho Amarelo " soils were grouped in two references each; three samples of "Latossolo Roxo " soil were grouped in one reference. The treatment effects were compared according to the non-parametrical tests of Kruskal-wallis and multiple comparisons.

Differences in stream frequency and texture ratio between the samples were parallel and it is concluded that the use of only one of these indexes is enough in the 
drainage network analysis based on circular samples.

An effect of the photographic scale was in case of samples representing the "Podzólico Vermelho Amarelo" soil in one of the groups, when comparisons were made of stream frequency and texture ratio between the two scales.

The description of the drainage patterns, permitted to differentiate between the poczol and latosol soil groups.

From the drainage parameters studied, the density provided the best differentiation between the different soil types; the mean length of drainageways was of minor significance.

It was recorded difference between the samples of one group of "Podzólico Vermelho Amarelo " soil and those of "Latossolo Vermelho Amarelo" in both groups.

The soil effect was better determined through the utilization of the 1:60,000 photographs, this been recommended for this type of work. It has the additional advantages of involving less photographic material and permits a better perception of relief. 
5.

1. INTRODUÇÃO

O conhecimento do solo é de interesse de todas as ciêrncias que estualam os componentes da faixa de contacto entre a crosta terrestre e a atmosfera, com excessão da hiarosfera. básico à Agronomia, pois detinindo as qualidades e os defeitos das unidades pecológicas, permite exploração tecnológica, propiciando maior rendı̉mento à empresa rural.

Hoje, a quase totalidade dos levantamentos de solo baseia-se no uso de fotografias aẻreas, desde como simples mapa básico atẻ como fornecedor de informações atravēs da fotopedologia.

Enquanto o processo de levantamento de solo por trajetórias no terreno com traaagens sistemáticas è demorado e oneroso, a utilização de fotografias aẻreas e o emprego de tēcnicas de fotointerpretação torna maior o rendimento de trabalho e maior a precisão, evitando interpolação e exigindo menor controle de campo.

Relevo, rede de drenagem, aspectos de erosão, tonalidade fotogrä́ica, vegetạão natural e uso da terra são parâmetros usualmente empregados pelo fotointërprete nos estudos de solos. Destes, os estudos da rede de drenagem e do relevo se destacam por permitir fäcil diferenciação de solos, 
havendo vantagem para o primeiro em relação ao segundo por possibilitar, mais facilmente a análise de caracteristicas quantitativas em adição às meramente descritivas, que apresentam a desvantagem de serem subjetivas.

A quantidade relativa de informações oferecidas pela fotopedologia a um levantamento de solos vai depender de seu grau de detalhamento taxonômico e cartogräfico e também das caracteristicas da imagem fotogräfica. Considerando-se um mesmo tipo de material fotográfico e mudando a escalia, poderá ocoxrer variação nos dados obtidos, sendo que quanto maior a escala, maior o detalhamento e menor a percepção de conjunto da paisagem.

Entre nōs, as escalas mais comuns de fotografias aéreas variam entre 1:8.000 e 1:60.000, havendo tendência para escalas reduzidas quando a cobertura aerofotográfica abrange maiores áreas. Sabendo-se que todas elas apresentam vantagens e desvantagens, torna-se necessário definir a capacidade da escala em função dos níveis de levantamentos e das unidades pedolögicas estudadas.

Levando em conta que o solo é função do clima, do material de origem, do relevo, dos organismos e do tempo, admite-se que não ocorram dois locais plenamente idênticos, o que poderä acarretar variabilidade nos padrões de uma mesma unidade pedolögica, dificultando uma ampla extrapolação de dados.

Pretende-se com este trabalho estudar as informações, obtidas com fotografias aéreas pancromåticas em três escalas diferentes, para três unidades pedolögicas, duas das quais repetidas em dois locais diferentes. 
2.1. Fotografias aēreas no estudo de solos.

AMARAL e AUDI (1972) referem-se à fotopedologia como sendo a utilização e interpretação de fotografias aéréas em levantamentosde solo, planejamentos conservacionistas e outros estudos de caracter pedológico.

Considerando que estudos de solo levam em conta principalmente as características do perfil e que a fotografia aérea registra apenas imagens de sua superficie, a fotopeđologia utiliza de correlações entre aspectos visiveis na fotografia e características intrínsicas do solo. Assim, GOOSEN (1968) cita três métodos principais de fotointerpretação para solos. O método da "análise de padrões" de FROST (1960), que estuda os padrões indicativos das condições de superficie e de subsuperficie, tais como relevo, drenagem, erosão, vegetação natural e cultivada e tonalidade fotográfica. O método mencionado por BURINGH (1960) como "análise fisiográfica" classifica o terreno segundo unidades fisiográficas. O método "análise de elementos" desenvolvido por BURINGH (1960) estuda sistematicamente os elementos relacionados com as condições de solo para traçar limites entre unidades pedológicas através do "princípio da convergência de evidências" enunciado por Colwell, que prevê a identificação de um objeto 
desconhecido atravēs da indicação semelhante da maioria dos indícios analisados.

A grande utilização de fotografias aéreas consequência, segundo RABBEN (1960), de três fatos fundamen tais: representação de grande área da superfície terrestre em cada fotografia; possibilidade de visualização trimendicional da superfície terrestre e dos objetos nela localizados, através de pares estereoscópicos; e representações permanentes e não tendenciosas dos objetos originais, pelas imagens foto grāficas.

Para GOQSEN (1968), a grande vantagem das fotografias aéreas está no oferecimento de visão panorâmica como meio de análise de fenômenos da paisagem.

FROST (1960) acentua a importância do estudo dę aspectos regionais antes de examinar o detalhe, para poder relacionar grandes feições regionais a fatores ambientais como fisiografia, geologia e clima.

ROURKE e AUSTIN (1951), CRESWICK e ROCKWELL (1959), BOMBERGER e DILL (1960), BURINGH (1960) e outros pesquisadores reconhecem que a fotografia aérea näo substitui completamente o trabalho de campo nos estudos de solo.

Entretanto, BURINGH (1960) afirma que aproximadamente a quinta parte do tempo de trabalho de campo para levantamento de solos, sem utilização de fotografias aêreas, é gasto na identificação e classificação das unidades, sendo o restante dispendido para locação dos limites de solos. Completando, afirma que a utilização de fotografias aéreas permite o traçado de grande parte desses limites, sendo necessárias menos verificações no campo, do que pelo rnétodo conven cional.

RABBEN (1960) considera mais produtivo em relação ao tempo e esforços despendidos, o trabalho usando a técnica de "pesquisa lógica", ou seja, quando o fotointérprete 
experiente, fazendo uso de probabilidades, pesquisa minucio samente só as äreas onde objetos de interesse possam ser encontrados, ao invēs de examinar detalhadamente o material de toda a ärea em estudo.

VERA (1964) comenta a rapidez conseguida com o uso da fotointerpretação no mapeamento detalhado de solos, ao nivel de séries, tipos e fases, e da capacidade de uso da terra de $120.000 \mathrm{~km}^{2}$ de terras agricolas do chile.

GOOSEN (1968) acrescenta ainda que a exatidão dos trabalhos pedológicos é altamente favorecida pela fotointerpretação, embora considere que seu valor seje limitado para levantamentos detalhados de solo, no que concorda BURINGH (1960).

FROST (1960) engloba todos os fatores limitan.tes do emprego da fotopedologia em três categorias: fatores Inerentes às técnicas e materiais fotogräficos; habilidade do fotointérprete; e características das paisagens.

AMARAL e AUDI (1972) afirmam que o uso de fotografias aêreas em escalas maiores possibilita maior detalha mento no levantamento de solo, acarretando, entretanto, menor rendimento de trabalho. Consideram como boa escala fotogräfica para levantamento pedológico detalhado a de cerca de 1:10.000, para levantamento semi-detalhado a de cerca de 1:25.000, e para levantamento de reconhecimento, uma escala prôxima de $1: 50.000$.

SMITH e AANDAHL (1957) afirmam que as unidades de solo não ocorrem ao acaso na paisagem, mas sim obedecendo a um padrão de distribuição relacionado com a forma do terreno.

RAY (1963) cita a consideração de Shultz e Cleaves de que a forma fisiogräfica seria o elemento mais importante para a fotopedologia.

Da mesma opinião é LUEDER (1959), que tambēm 
cita a drenagem superficial como indicador seguro das condi ções do terreno.

FRANÇA (1968) conclui que a análise e a inter pretação do padrão de drenagem fornecem indícios suficientes para a distinção entre solos.

AUDI (1972), estudando atributos de canais de drenagem em fotografias de escala 1:25.000, admite a possibilidade de diferenciação de famílias de solo com relativa segurança atravēs da fotointerpretação.

Para FROST (1960), a fotopedologia pode ser executada através dos padröes criados pela natureza do material de origem, o modo de deposição e os ambientes climático ', biótico e fisiogräfico. Estes padrões devem ser interpretados seguindo três principios importantes: solos semelhantes, aparecem nas fotografias aéreas com padrões semelhantes; solos diferentes aparecem com padrões diferentes; e desde que caracteristicas da imagem fotográfica tenham sido correlacionadas com propriedades do solo, observadas no campo e no labo ratōrio, muitas propriedades importantes de solos semelhantes podem ser inferidas por fotointerpretação.

\subsection{Caracteristicas das redes de drenagem e sua signifi- cância pedológica}

A análise de bacias hidrográficas tem sido motivo de estudos para correlação com solos, com obtenção de sucesso. Coube a Horton a primazia da abordagem quantitativa das características de bacias hidrográficas em 1945 (FRANÇA 1968).

Segundo VON ENGEIN (1942), das observações visuais de Playfair, em 1802, ficou estabelecida a lei das junções concordantes, pela qual os rios são considerados responsáveis por seus vales e ao mesmo tempo concordantes com eles.

HORTON (1945) estabelece duas leis que conferem 
à lei de Playfair um significado quantitativo. As leis de Horton relacionam o número e o comprimento de rios às diver sas ordens de ramificação da rede hidrográfica. Para tal, Horton precisou inverter a sequência de numeração da hierar quia fluvial usada pela classificação europëia, de modo que pudessem ser comparáveis bacias hidrogräficas de ordens equivalentes, numeração esta que passou a ser crescente a partir dos menores tributärios da bacia. Mais tarde, STRAHLER (1952) modifica ligeiramente a hierarquia fluvial proposta por Horton, para a forma que hoje é aceita pelos pesquisadores.

Alëm de prever igual nümero de ordem de bacias a serem comparáveis, STRAHLER (1952) adverte que as bacias devem apresentar semelhança geomētrica.

HORTON (1945) considera que enquanto a composição da rede de drenagem tem alto grau de significância hidrológı́ca, o padrão isolado tem pouca, embora seje altamente significativo como indicador de controle geológico.

* Estudando redes de drenagem através de amostragem com bacias hidrográficas, Horton, Strahler e outros pesquisadores como Maswell, coates e Smith, determinaram uma sērie de relações observadas, levando em consideração o número e o comprimento de rios e suas ordens de ramificação (FRANÇA, 1968).

HORTON (1945) apresenta as relações frequência de rios e densidade de drenagem para, além da ordem de rios, expressar quantitativamente o grau de desenvolvimento da drenagem superficial.

A frequência de rios expressa a relação entre o nǘrero total de canais de drenagem e a área da bacia, enquanto que a densidade de drenagem dimensiona o comprimento total de canais por unidade de área.

SMITH (1950) propõe o indice textura topográfiua com o propósito de expressar o espaçamento entre os canais 
de drenagem. Para tal, prevê a relação entre o número de crênulas numa curva de nivel de um bom mapa topográfico dentro de uma bacia hidrográfica e o perimetro desta bacia expresso em milhas. Este mesmo autor, propõe o cálculo da razão de textura média para, através de limites de valores deste Indice, classificar a área amostrada quanto à textura topográfi ca.

FRANÇA (1968), estudando bacias de drenagem para caracterização de unidades de solo, modifica estes índices de Smith com o emprego de fotografias aẻreas para calcular o número de canais de drenagem, ao invês de crênulas em mapas topográficos, e referenciando a valor de perimetro em quilômetros.

Indicações sôbre a relação infiltração/deflú vio, capacidade de infiltração permeabilidade e textura de materiais presentes em uma área, são fornecidas pela análise da drenagem superficial; em geral, um padrão de drenagem bem desenvolvido indica a existência de materiais pouco permeáveis, enquanto o contrário è indicador de alta infiltração e boa permeabilidade (LUEDER, 1959).

Qualitativamente, o padrão de drenagem è descrito por PARVIS (1950) com designações que lembram a configuração da rede.

LUEDER (1959) sugere para a caracterização de um padrão de drenagem, a descrição de seu grau de integração, densidade, grau de uniformidade, orientação, grau de contro le, angularidade, ângulos de confluência e seu tipo ou padrão segundo Parvis.

MILLER e MILLER (1961), no estudo de drenagem para interpretação geológica, verificam que certas anomalias do padrão de uma rede de drenagem, são de grance importância. Em consequência, RICCI e PETRI (1965) propoem a descrição de mais uma característica, anomalias, em adição às de Lueder.

PARVIS (1950) considera que enquanto os padrões 
de rios de ordens inferiores informam o pesquisador a respeito de solos ou de substratos rochosos, os padrões de rios de ordens mais elevadas mostram a influência de controles estruturais.

Para FROST (1960) o estudo de redes de drenagem superficial e de aspectos do micro-relevo pode fornecer informações significativas com respeito às propriedades do so 10.

RAY e FISCHER (1960) usando a ārea de bacias hidrogräficas e a área de amostras circulares de $10 \mathrm{~km}^{2}$ para - cālculo de densidade de drenagem em estudo sobre a litologia, concluem que as amostras circulares fornecem determina ções mais consistentes deste Indice, para qualquer tipo de rocha, do que as amostras representadas por pequenas bacias.

FRANÇA (1968) considera a densidade de drenagem determinada em amostras circulares de $10 \mathrm{~km}^{2}$, entre os parâmetros üteis dos elementos da drenagem estudados, para fazer distinção entre unidades de solo classificadas a nivel de série. Este mesmo autor observa correlação altamente significativa entre a densidade de drenagem determinada em amostras circulares e a razão de textura mëdia. A estas mesmas conclusões chega FADEL (1972), relacionando caracteristicas da rede de drenagem a outras séries de solos.

A densidade de drenagem medida em amostras circulares de $10 \mathrm{~km}^{2}$ também é considerada entre as melhores características da rede de drenagem para distinção entre unidades de solo por MARCHETTI (1969), VASQUES FILHO (1972) e LEÃÒ (1973).

CARVALHO (1977) observa que mudanças nas características qualitativas do padrão de drenagem refletem controle geológico.

FRANÇA (1968) e depois VASQUES FILHO (1972), trabalhando com diferentes unidades de solo, verificam que a composição e as características do padrão de drenagem variam 
com a natureza do solo, podendo sofrer modificações por influência de controles geológicos.

FRANÇA (1968) considera haver influência da posição topográfica sobre a composição e caracterização do padrão de drenagem, no que concorda SOUZA (1975).

MARCHETTI (1969) verifica que indices baseados na rede de drenagem estão correlacionados com indices de relevo, concluindo também que tanto as características das bacias hidrográficas e das redes de drenagem como as caracte risticas de relevo, dependem da natureza do solo.

VASQUES FILHO (1972), CARVALHO (1977) e SILVA (1977) consideram vantajoso o emprego de amostras circulares de $10 \mathrm{~km}^{2}$ sobre as amostras representadas por bacias hidrográficas para a caracterização de redes de drenagem visando a distınção entre unidades de solo. SOUZA (1975) também considera as amostras circulares vantajosas para os mesmos fins citados, porém ressalva que o tamanho da amostra circular deva ser adaptado em relação à extensão da unidade pedológica investigada. Entretanto, FREIRE (1977) considera que os indices frequência de rios e densidade de drenagem medidos em amostras circulares, são bons para distinção de unidades de solo por elas representados e independente do tamanho das mesmas.

KOFFLER (1976a) usando imagens fotográficas de diferentes escalas, obtidas por aviões e satélites terres tres, e variando o tamanho da amostra circular, considera a densidade de drenagem como 0 melhor dos índices estudados para a distinção de unidades de solo, ressaltando, entretanto, que há redução da separabilidade dos solos à medida que a escala diminui.

Complementando seu trabalho Inicial, KOFFLER (1976b), usando amostras circulares variando de 10 a $100 \mathrm{~km}^{2}$ e fotografiass aéreas em escala 1:60.000, verifica que a caracterização quantitativa de um padrão de drenagem através 
dos Indices densidade de drenagem, frequência de rios e comprimento médio de canais, independe do tamanho da amostra, desde que seje representativa, recomendando que a escolha do tamanho da amostra seja vinculada à densidade relativa da rede de drenagem.

DEMERIO (1977) verifica que os Indices densi dade de drenagem, frequência de rios e razão de textura diferem entre si com a variação da escala fotogräfica.

$$
\text { KOFFLER (1976a) e depois DEMETRIO (1977) suge - }
$$

rem haver interesse no estudo de um Indice que relaciona comprimento total dos canais com seu nümero na amostra, ou seja, o comprimento médio dos canais de drenagem, para correlacio nar com solo. 
16.

\section{MATERIAL E METODOS}

\subsection{Localização geográfica das amostras}

Utilizando material fotográfico em três escalas diferentes, foi feita a interpretação de características da rede de drenagem superficial em 18 amostras circulares de $10 \mathrm{~km}^{2}$ cada uma, reunidas em cinco grupos correspondentes a diferentes referências de solo, distribuidas em locais de ocorrência destes solos no Estado de São Paulo, segundo levantamento pedológico, coincidentes com áreas de onde houvessem coberturas aerofotográficas em três escalas.

As amostras 1, 2 e 3, correspondentes a referência de solo $S_{1}$, de solo Podzólico Vermelho Amarelo, foram localizadas em Campinas e Valinhos, entre as sedes destes municipios (Fig. 1) (BRASIL, 1974a). As amostras 4, 5, 6 e 7, correspondentes a $\mathrm{S}_{2}$, também de solo Podzólico Vermelho Amarelo, foram localizadas nos municípios de Rio Claro, Leme, Araras e Santa Cruz da Conceição (Fig. 2) (BRASIL, 1971a, 1969).

Em Latossolo Vermelho Amarelo, foram localiza das as amostras de números $8,9,10$ e 11 , da referência $\mathrm{S}_{3}$, nos municípios de Moji-Guaçu e Aguaí (Fig. 3), e as de números $12,13,14$ e 15 , da referência $S_{4}$, nos municipios de Ara- 


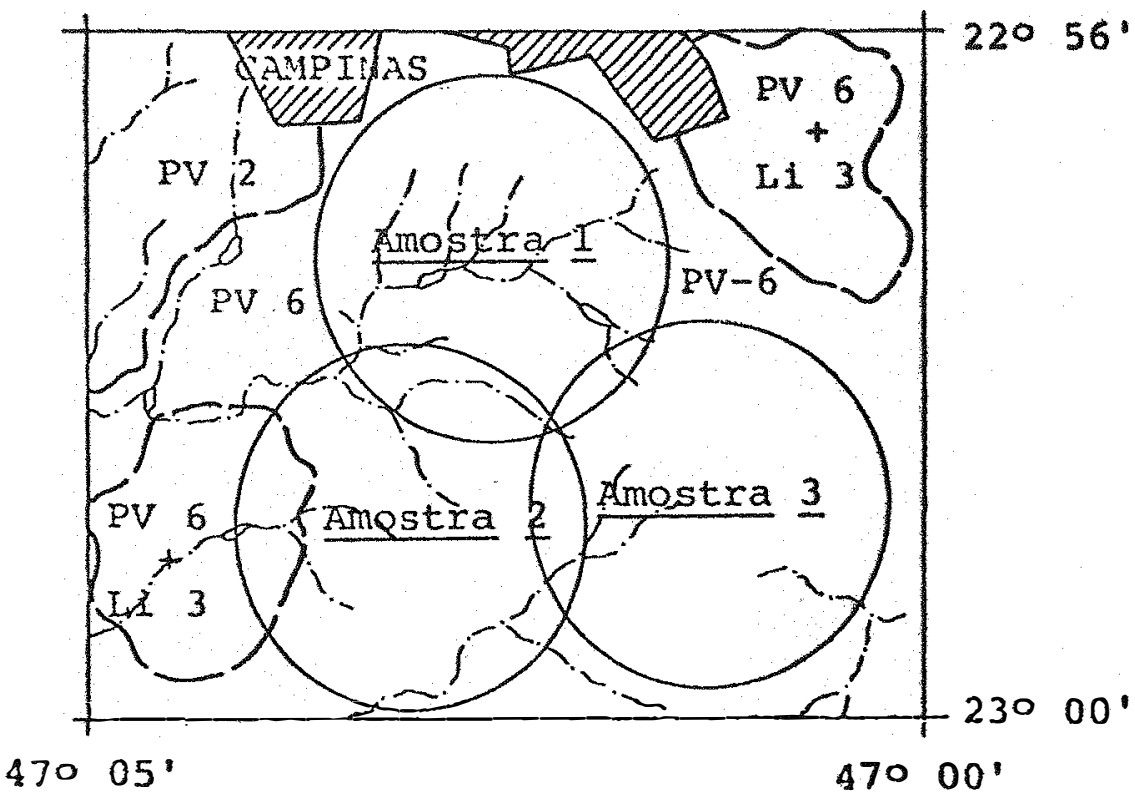

Figura 1. Localização geográfica e unidades de solo das amostras 1,2 e 3. 


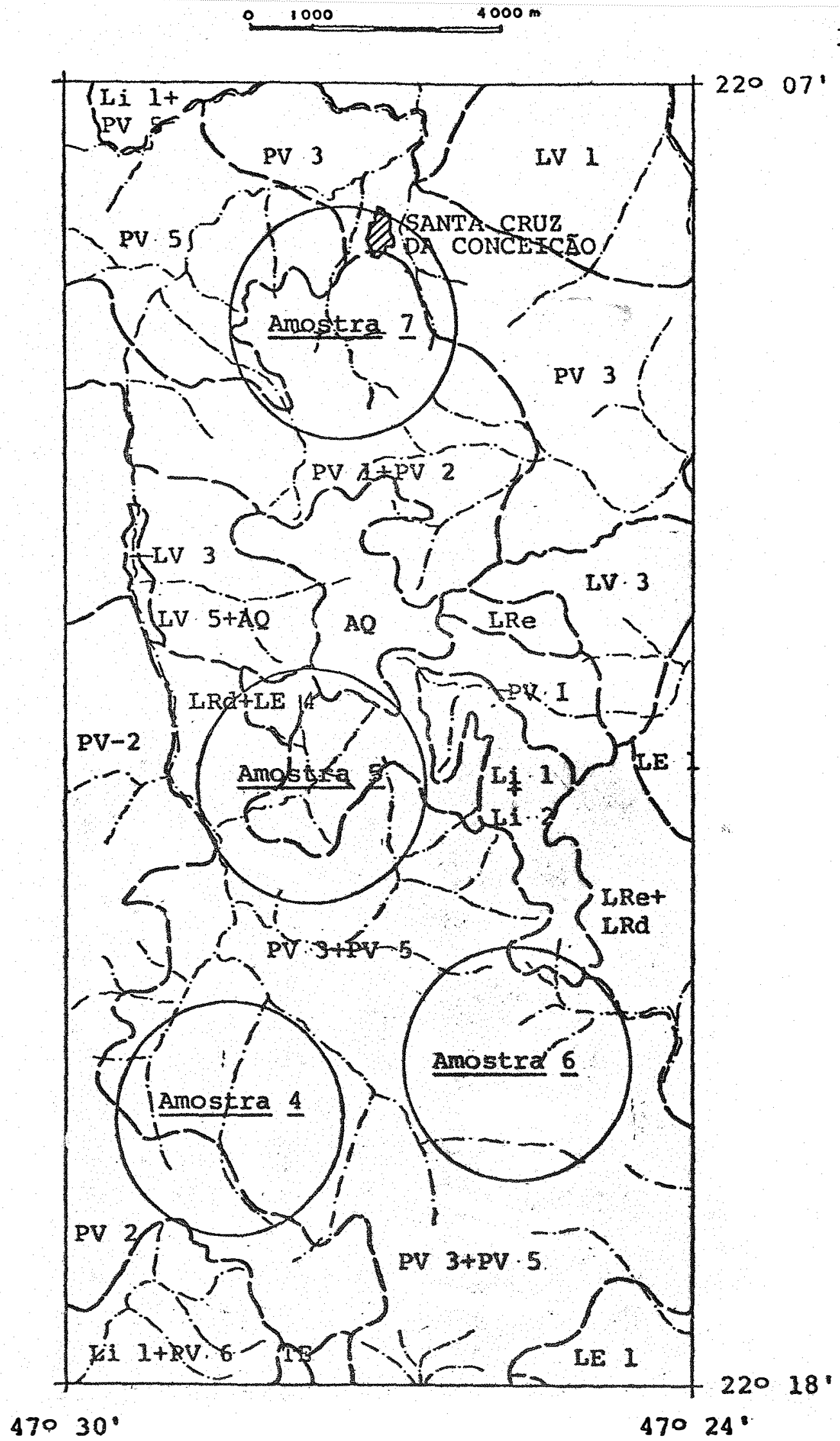

18 .

Figura 2. Localização geográfica e unidades de solo das amostras $4,5,6$ e 7 . 


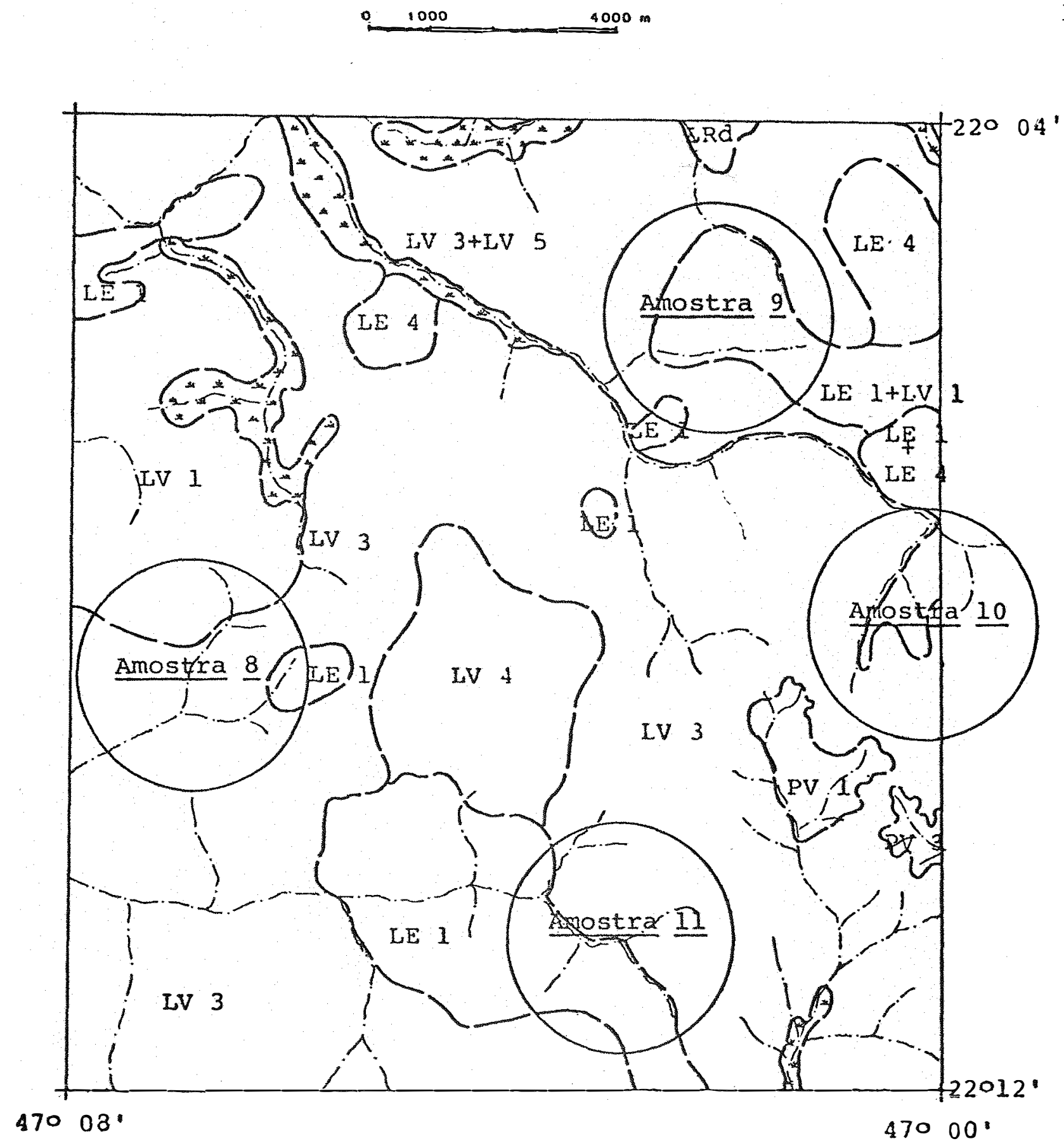

Figura 3. Localização geográfica e unidades de solo das amostras 8, 9, 10 e 11 . 
ras, Conchal e Moji-Mirim (Fig. 4) (BRASIL, 1969, 1971b, 1972, $1974 b)$.

As amostras 16,17 e 18 , de referência $s_{5}$, em Latossolo Roxo, foram localizadas nos municípios de Leme e Araras (Fig. 5) (BRASIL, 1971a, 1969).

\subsection{Geologia}

As áreas estudadas situam-se em duas Províncias Geomorfológicas, o Planalto Atlântico e a Depressão Periférica. As amostras 1, 2 e 3 localizam-se na primeira e as restantes, na ültima.

O Planàlto Atlântico ou Cristalino, na área amostrada, apresenta-se com as seguintes características geomorfológicas: relevo de colinas amorreadas com topos planos e vertentes com inclinação e declividade variando de 10-20\% (SÃO PAULO, 1964).

A Depressão Periférica compreende uma ārea sensivelmente rebaixada pela erosão, entre as terras altas do Planalto Atlântico e as cristas elevadas das cuestas basálticas. As altitudes são reduzidas e os "sills" de diabásio ấ existentes não constituem causa de acidentabilidade do relevo, salvo os condutos magmáticos verticais, que representam uma área infima (SÃO PAULO, 1975).

O quadro 1, resume a cronogeologia do substrato dos locais amostrados (SÃO PAULO, 1974).

3.3. Clima

O clima da região a que pertencem as amostras selecionadas está classificado pelo sistema Koeppen no tipo 

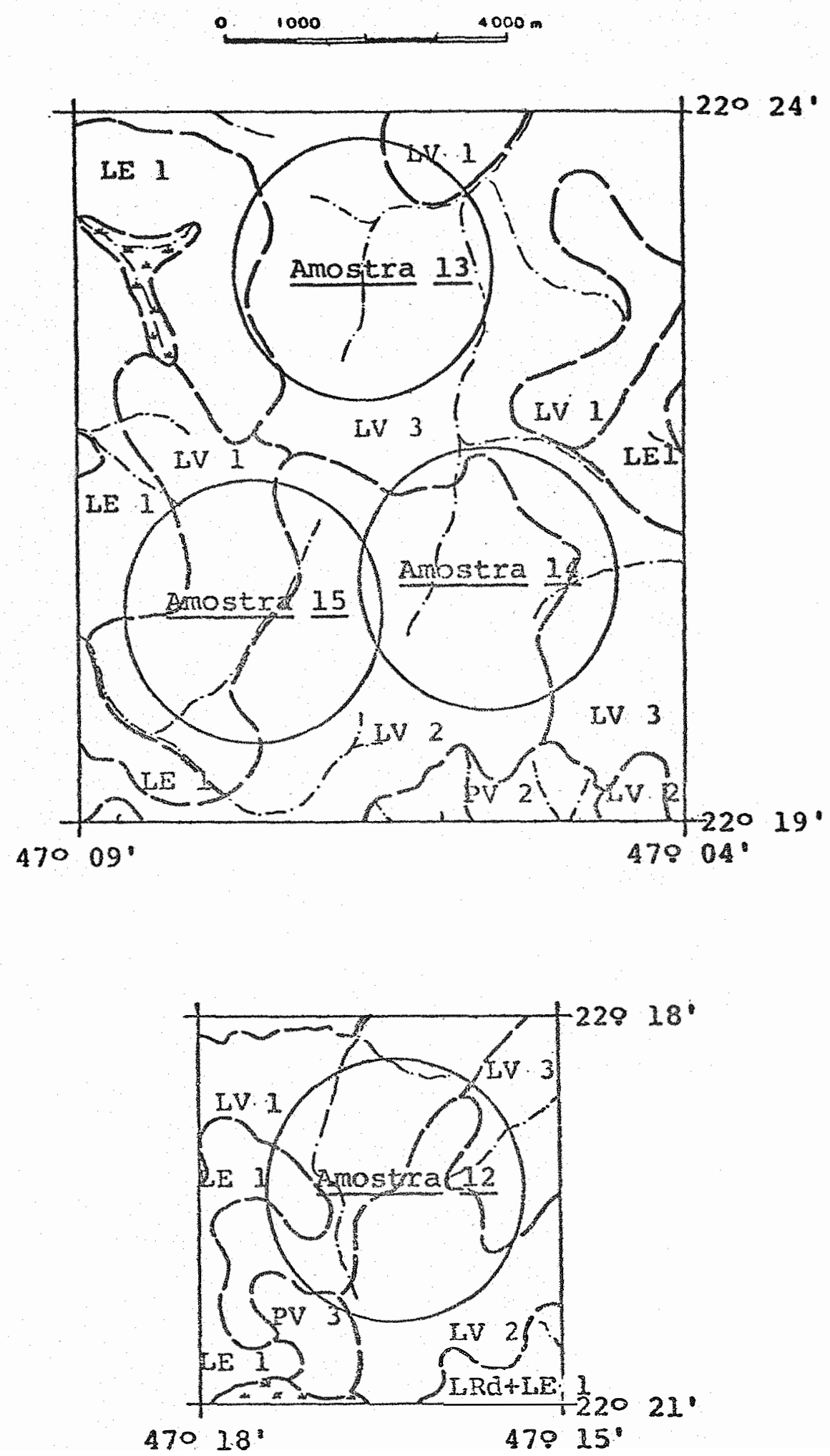

Figura 4. Localização geográfica e unidades de solo das amostras 12, 13, 14 e 15. 
22.

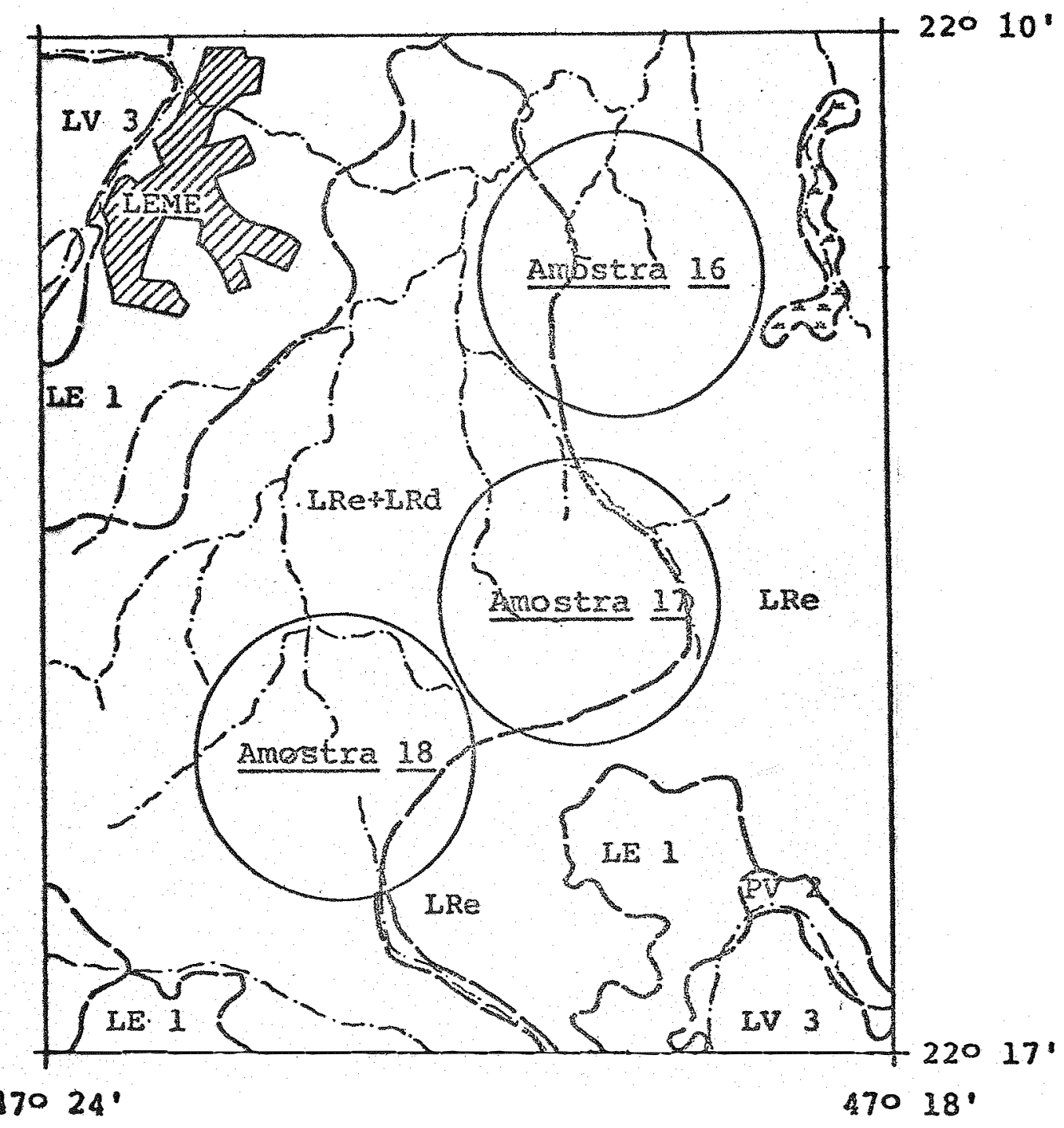

Figura 5. Localização geogrärica e unidades de solo das amostras 16, 17 e 18 . 


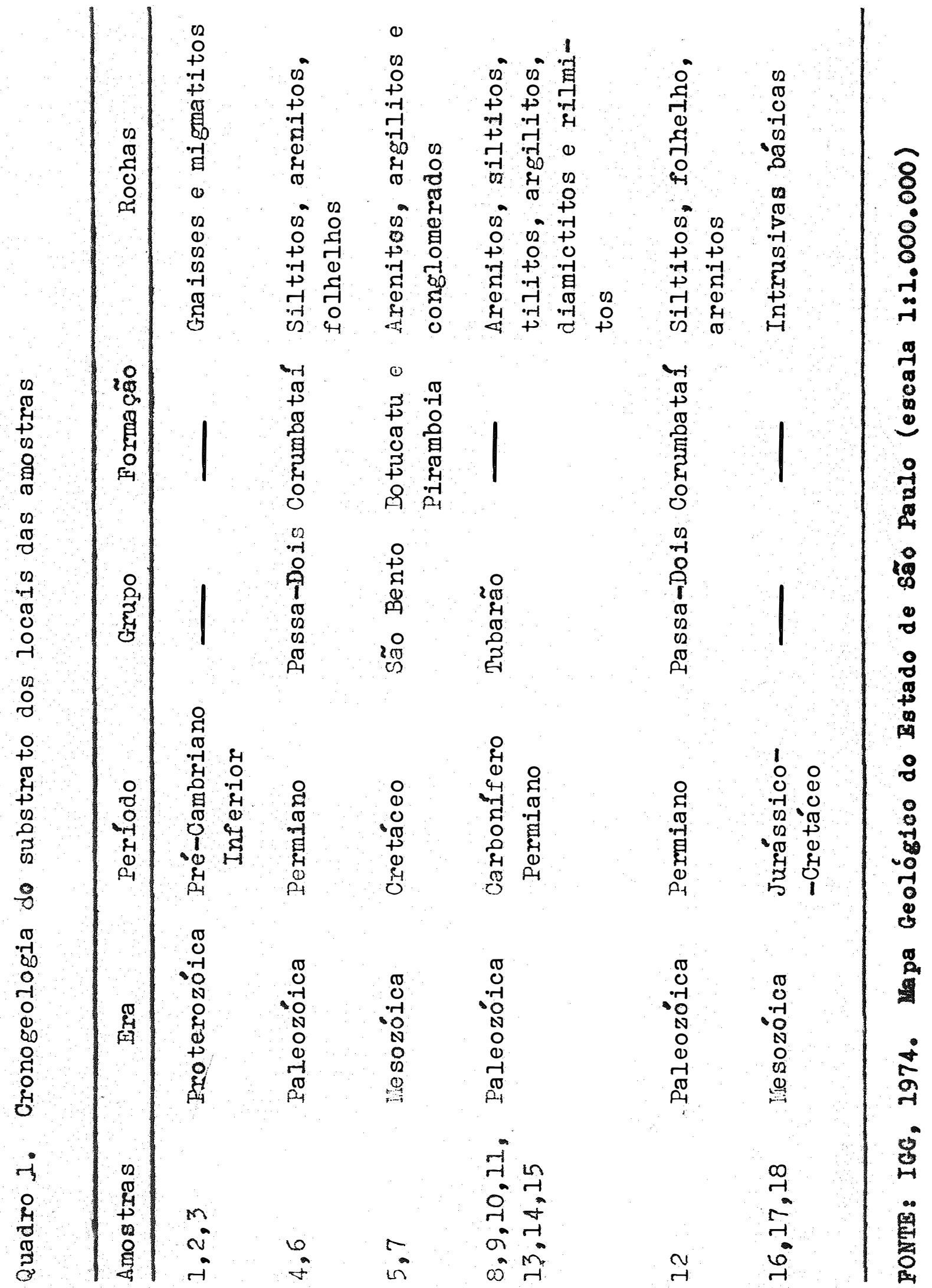


Cwa, ou seja, subtropical úmido. As características deste clima são: precipitação superior a $1.000 \mathrm{~mm}$ anuais e temperatura mëdia inferior a $188 \mathrm{C}$ no mês mais frio e superior a 228 C no mês mais quente (SETZER, 1966).

Baseado na classificação do clıma pela efetividade da precipitação, as ãreas amostradas enquadram-se no tipo Ccw, ou seja, clima úmido subtropical com estiagem no Inverno, ocorrendo menos de $30 \mathrm{~mm}$ de chuva no mês mais frío (SETZER, 1966).

\subsection{Solos nas äreas amostradas}

Segundó levantamento peçológico semi-detalhado de OLIVEIRA et alii $(1979, *)$, as äreas amostradas englobam 17 unidades de mapeamento conforme localização nas figuras de 1 a 5. A simbologia nas figuras ë a mesma usada no levantamento.

Parte da amostra nümero 10 (Fig. 3) foi locada fora da área levanta pora OLIVEIRA et alii (*). No entanto suas caracteristicas fotopedológicas indicam que 0 solo de toda a amostra é do tipo B jatossólico.

- quadro 2 resume informações sobre as unidades pedológicas de cada amostra (OLIVEIRA et alii, 1979,*), a localização segundo limites municipais e a variação de altitude por interpolação de curvas de nỉvel de follhas topográficas (BRASIL, 1969, 1971a, 1971b, 1972, 1974a, 1974b).

Segundo OIIVEIRA et alii (1979, *), algumas

(*) OLIVEIRA, J.B.: J.R.F.MENi; J.L. BARBIERI; C.L. ROTTA e W.A. TREMOCOLDI. Levantamento peỏológico semi-detalhado do Estado de São Paulo - Quadrícula de Araras. Campinas, Instituto Agronômico (não publicado). 
Quadro 2. Unidades podolócicas, localização municipal e veriação de altitude das áreas amostradas

\begin{tabular}{|c|c|c|c|}
\hline \multirow[t]{2}{*}{ Amostra } & Unidades & Ihunicipios & AItitude \\
\hline & Referência $S_{1}-$ Podzó & Iico Vermelho Amarelo & $\mathrm{m}$ \\
\hline 1 & PV6 & Campinas & $660-770$ \\
\hline 2 & $\mathrm{PV} 6, \mathrm{PY} 6+\mathrm{Ii3}$ & Campinas, Valinhos & $660-770$ \\
\hline \multirow[t]{2}{*}{3} & PV6 & Valinhos, Campinas & $700-790$ \\
\hline & Referência $S_{2}-$ Podzó & Ifeo Vermelho Amarelo & \\
\hline 4 & $\mathrm{PV} 2, \mathrm{PV} 3+\mathrm{PV} 5$ & Rio Claro & $640-750$ \\
\hline 5 & $\mathrm{IVI}, \mathrm{PV3}+\mathrm{PV} 5, \mathrm{IR} d+\mathrm{IE} 4, \mathrm{AQ}$ & Ieme & $650-785$ \\
\hline 6 & $\mathrm{PV} 3+\mathrm{PV} 5, \mathrm{I}+1+\mathrm{I} 12$ & Ieme, Araras & $650-745$ \\
\hline \multirow[t]{2}{*}{7} & $\mathrm{PV} 1+\mathrm{PV} 2, \mathrm{PV} 3, \mathrm{PV} 5$ & Santa Cruz da Conceição & $610 \div 745$ \\
\hline & Referência $S_{3}$ - Iatos & solo Vermelho Amarelo & \\
\hline 8 & $I V 1, I V 3, I E I$ & Noji-Guaçu & $590-640$ \\
\hline 9 & $\mathrm{IVV} 3+\mathrm{IJV} 5, \mathrm{IEI}+\mathrm{LVI}$, IEI & Agraí & $580-675$ \\
\hline 10 & $\mathrm{LV} 3, \operatorname{IE} 4+\operatorname{IEI}$ & Ito ji-Guaçu & $610-730$ \\
\hline \multirow[t]{2}{*}{11} & $\mathrm{IV} 3, \mathrm{IEI}$ & Llo ji-Guaçu & $610-700$ \\
\hline & Referência $S_{4}$ - Latos & solo Vermelho Amarelo & \\
\hline 12 & $\mathrm{IV1}, \mathrm{IV} 2, \mathrm{IV} 3, \mathrm{IEI}, \mathrm{PV} 3$ & Araras & $580-665$ \\
\hline 13 & $\mathrm{IVI}, \mathrm{IV} 3, \mathrm{IEI}$ & Conchal, Noji-lilirim & $640-700$ \\
\hline 14 & $\mathrm{IV} 2, \mathrm{IV} 3$ & toji-mirim, Conchal & $660-74$ \\
\hline \multirow[t]{2}{*}{15} & $I V 1, I V 2, I E I$ & Conchal & $640-725$ \\
\hline & Referência $S_{5}$ - Iratos & :010 Roxo & \\
\hline 16 & Ire, IRe*IRd & Leme & $580-700$ \\
\hline 17 & IRe, IRe + IRd & Ieme, Araras & $600-700$ \\
\hline 18 & InRe, IRe + IRd & Araras, Ieme & $600-65$ \\
\hline
\end{tabular}


caracteristicas das unidades pedológicas das áreas estudadas, podem ser assim descritas:

a) LRe - Unidade Ribeirão Preto

Classificação: Latossolo Roxo Eutrôteico, A moderado, textura argilosa, relevo swave ondulado

Caracteristicas: Solo argiloso, poroso e expesso

B latoßsólico ş̣pesso (muperior a $200 \mathrm{~cm}$ no $B_{2}$ ), com orande homogeneidade vertical

Relevo suave ondulado, com colinas de topo ligelramente abaulado e declives Listeriones a 5 .

Altitude varisando de 560 a $750 \mathrm{~m}$

Material de origem - resultante do intemperismo de dusbésios

Vegetaça prothintra - matas

Ocupação atual - culturas

b) LRd - Unidade Barão Geraido

Classificação: Eatossolo Rozo Distrófico, A moderado, textura argilosa, relevo sugve ondulado

Caracteristicas: Solo argiloso, poroso e espesso

B latossôlico espesso, com grande homogeneidade verustal

Relevo ondulado, com colinas de lançantes Iongos (500 m), com topos ligeiramente abaulados e declives inferiores a 5 웅

Altitude varianco de 560 a $750 \mathrm{~m}$ Matexial de origem - resultante do intemperismo e retrabahamento de basaltos Vegetậão primitนที - cerradões e matas Uso atua - critevas 


\section{c) LE 1 - Unidade IImeira}

Classificação, Latossolo Vermelho Escuro älico, A moderado, textura argilosa, relevo aplainado ou suave ondulado

Caracteristicas: Solo de textura argilosa, poroso, profundo e bem drenado

D latossolico espesso, com textura muito arotiose e grande homogeneidade verbies

Relero wave ondulado com vertentes Ion-

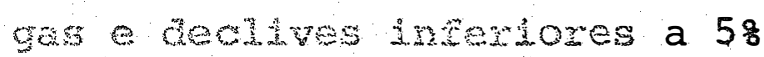

Altibue vasanco de 380 a $740 \mathrm{~m}$

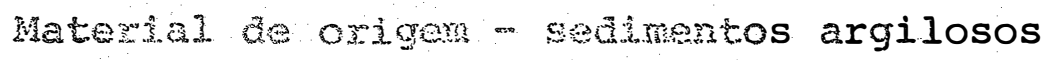
metrababado provenientes do intemperisne de axsilitos e siltitos dos grupos rubara e Passa Dois (forma-

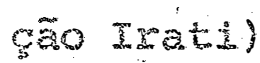

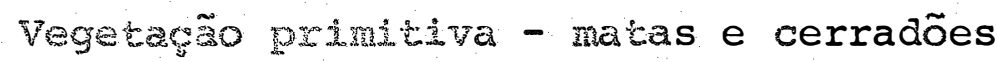

uso atrai - culturas

d) IE 4 - Unidade Horóolariaia

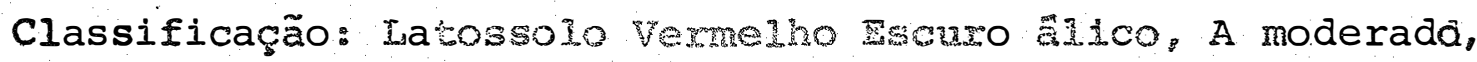
textura media, relevo suave omdulado

Caracter Isticas: Solo de textura måda. poroso, bem drenado

3 Latossolico espesso. con grande homogenesade vertical

Relevo suave ondulado constituido de elevarós de topo Ieremente abaulado, mase plano, con declives inferiores 2 58

Altibure variando de 450 a $700 \mathrm{~m}$ Material de origem - seamentos arenosos proventemtes de arantos finos do 
grupo Tubarão com contribuição do material retrabalhado de basaltos Vegetação primitiva - cerradões e cerrados

Uso atual - culturas, reflorestamentos e pastagens

e) IV 1 - Uniaade Mato Dentro

Classificação: Latossolo Vermelho Amarelo àlico, A moderado, textura argilosa, zelevo aplainado ou suave ondulado

Caracteristicas: Solo de textura barrenta ou argilosa no horizonte A e argilosa no horizonte B, poroso, profurdo, bem drenado

B latossólico apểico, espesso e homogêneo verticalmente

Relevo aplainado a suave ondulado com declives em geral inferiores a $5 \%$

Altitude variando de 580 a $730 \mathrm{~m}$

Material de oxigem - resultante do retrabalhamento de material proveniente de sedimentos argilosos do grupo Tubarão Vegetação primitiva - matas e cerradões Uso atual - culturas

f) LV 2 - Unidade Speculaas

Classificação: Latossolo Vermelho Amàrelo älico, A proeminente, textura média, relevo aplainado a suave ondulado

Características: Solo de textura mẻdia, profundo

B latossólico apédico, espesso e homogêneo verticalmente

Relevo aplainado a suave ondulado com declives que variam de 2 a $5 \%$ 
Altitude variando de 580 a $750 \mathrm{~m}$

Material de origem - resultante do retrabalhamento de sedimentos grosseiros do grupo Tubarão e da formação Irati (predominância de areia fina sobre areia grossa), com contribuição de materiais provenientes de arenitos da Eormação Botucatu (predominância de areja grossa sobre areia fina)

Vegetação primitiva - cerrados e cerradões Uso atual - culturas e reflorestamentos

g) LV 3 - Unidade Laranja Azeda

Classificação: Latossolo Vermelho Amarelo álico, A moderado, textura média, relevo suave ondulado

Caracteristicas: Solo de textura média com mais de $20 \%$ de argila, profundo, bem drenado

B latossólico apédico espesso

Relevo suave ondulado com declives variando entre 3 a $5 \%$

Altitude variando de 580 a $730 \mathrm{~m}$

Material de origem - resultante do retrabalhamento de sedimentọs grosseiros do grupo Tubarão, com contribuição em alguns casos (aumento considerável da fração areia grossa) de material proveniente de arenitos da formação Botucatu

Vegetação primitiva - cerrados e cerradões

Uso atual - culturas, reflorestamentos e pastagens 


\section{h) LV 5 - Unidade Coqueiro}

Classificação: Latossolo Vermelho Amarelo älico, A moderado, textura média, relevo suave ondulado

Características: Solo de textura média com menos de $20 \%$ de argila, profundo, bem drenado

B latossôlico apédico, espesso

Relevo suave ondulado com declives variando entre 3 a $5 \%$

Altitucie variando de 580 a $670 \mathrm{~m}$ Material de origem - resultante do retrabalhamento de sedimentos grosseiros do grupo Tubarão, com contribuição em alguns casos (aumento considerävel de fração areia grossa) ce material proveniente de arenitos da formação Botucatu

Vegetação primitiva - cerrados e cerradões Uso atual - culturas, reflorestamentos e pastagens

\section{i) PV 1 - Unidade Alva}

Classificação: Podzólico Vermelho Amarelo abrüptica, A moderado, textura média, relevo ondulado ou forte ondulado

Características: Solo profundo com horizonte A espesso (em geral superior a $60 \mathrm{~cm}$ ), arenoso, assente abrupticamente sobre um B textural, espesso e extremamente duro

Relevo ondulado a fortemente ondulado com declives de 8 a 15\%

Altitude variando de 540 a $780 \mathrm{~m}$ Material de origem - arenitos finos do grupo Tubarão

Vegetação primitiva - matas

Uso atual - culturas 


\section{j) PV 2 - Unidade Serrinha}

Classificação: Podzólico Vermelho Amarelo älico, A moderado, relevo suave ondulado a ondulado

Caracteristicas: Solo profundo com horizonte A moderado, arenoso, assente sobre um B textural, espesso, de textura média

Relevo suave ondulado (declives entre 4 a $7 \%$ ) a ondulado (declives até 15\%)

Altitude variando de 620 a $780 \mathrm{~m}$

Material de origem - proveniente do retrabalhamento de arenitos finos das formações Corumbataí e Botucatu

Vegetação primitiva - matas

Uso atual - culturas, pastagens e reflorestamentos

1) PV 3 - Unidade Holambra

Classificação: Podzólico Vermelho Amarelo Distrôfico, A moderado ou proeminente, textura mêdia

Características: Solo poroso, Exiāvel, profundo, com horizonte A moderado, de textura areno barrenta, assente sobre um B textural espesso, com apreciável diferenciação textural

Relevo suave ondulado

Altitude variando de 620 a $780 \mathrm{~m}$ Material de origem - sedimentos areno argilosos resultantes do retrabalhamento de materiais provenientes de rochas básicas

Vegetação primitiva - matas

Uso atual - culturas 
m) PV 5 - Unidade Santa Cruz

Classiflcação: Podzölico Vermelho Amarelo ālico, A moderado, textura argilosa, relevo suave onđulado

Caracteristicas: Solo moderadamente profundo (horizontes $A$ $+B<120 \mathrm{~cm}$ ), bem drenado, com horizonte A moderado assente sobre um $B$ textural, argiloso a muito argiloso Relevo suave ondulado

Altitude variando de 620 a $780 \mathrm{~m}$

Naterial de origen - sedimentos de formação corumbataî

Vegetação primitiva - matas

ocupação atual - culturas

n) PV 6 - Unidade Valinhos

Classificação: Podzólico Vermelho Amarelo, A moderado, textura argilosa, relevo suave ondulado a ondu1 ado

Caracteristicas: Solo profundo com ampla variação morfológica, apresentando horizonte superficial de textura areno barrenta a areno argilosa, passando a argilosa nos horizontes inferiores

Relevo suave ondulado a ondulado, constituido pelas áreas rebaixadas do $\mathrm{Pla}-$ nalto Atlântico limítrofes com a Depressão Perifêrica

Altitude variando de 600 a $770 \mathrm{~m}$ Material de origem - resultante do intemperismo de rochas do Prë-cambriano, principalmente graisses $\overline{~ c o m ~ c o n t r i-~}$ buição de sedimentos do Permiano Vegetação primitiva - matas Uso atual - pastagens e culturas 


\section{o) AQ - Unidade Panorama}

Classificação: Solos arenoquartzosos profundos podzólicos, A moderado, äl1co, relevo suave ondulado

Caracteristicas: Solo arenoso ao longo do perfil e com peçuena diferenciąão entre as camadas subjacentes ao horizonte $A$ (sequência de horizontes $A, C)$, profundo, excessitranente drenado

Relevo suave ondulado com declives de 3 a 7 응

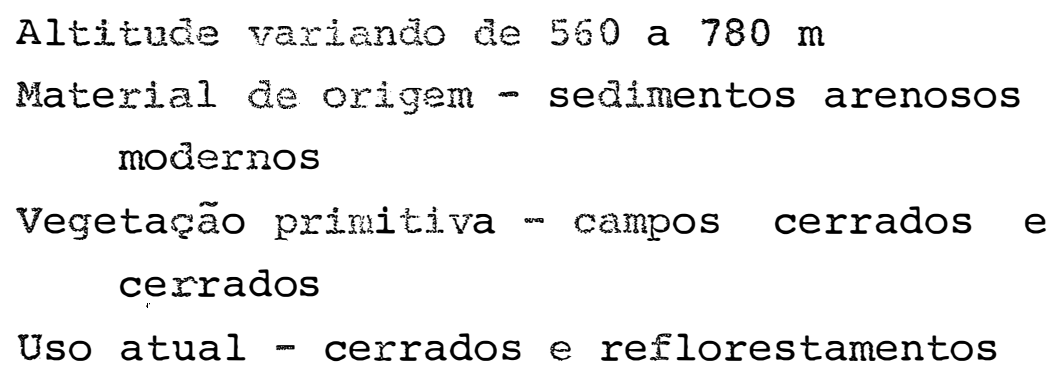

p) Li 1, Li 2, Ii 3 - Solos Litölicos (ou Litossolos)

classificação: Li 1 - Solos Litôlicos, A moderado ou proeminente, substrato arenito fino ou siltito

Li 2 - Solos Istólicos, A moderado, substrato basalto

Ii 3 - Solos Litólicos, A. moderado, substrato granito-graisse

Características: Solos com pequena espessura, geralmente inferior a $30 \mathrm{crn}$; apresentando perfil do tipo $\mathbb{A}_{\mathrm{R}}$ g sendo crue a rocha subjacente ern geral se apresenta alterada e branda, com horizonte A moderado, podenco ocorrer tambëm A proeminente

Solos gezalmente eutróficos, associados a outras unidades 
Textura variävel, relacionada com a natureza do substrato. Os solos derivados do basalto são argilosos; os derivados de granito-gnaisses, barrentos e os derivados de sedimentos siltosos ou arenosos do grupo Tubarão, arenosos ou barrentos

Relevo ondulado ou ondulado dissecado

Vegetação primitiva - matas

Uso atual - culturas, especialmente naqueles derivacios de sedimentos do grupo Tubarão

\subsection{Material fotográfico}

Foram utilizadas fotografias aëreas verticais, pancromāticas, de formato de $23 \times 23 \mathrm{~cm}$, de três diferentes coberturas aerofotográficas. Todas as rotografías apresentavam recobrimento médio de $60 \%$ no sentido da faì de vôo e de $30 \%$ entre as faixas, o que permite exame estereoscôpico de pares fotográficos e total cobertura fotogräfica de ärea.

A cobertura mais antiga é a de escala aproximada 1:60.000, executada pela USAF (United States Air Force), para o Governo Brasileiro. As fotos utilizadas foram tiradas durante os meses de abril a julho de 1965.

A cobertura mais recente ê a de escala aproximada 1:35.000, executada pela Terrafoto S.A. para a Secretaria de Planejamento do Estado de São Paulo. As datas de tomada destas fotografias variam nos meses de junho e julho de 1978 .

A terceira cobertura utilizada e a de escala aproximada 1:25.000, executada pela Vasp Aerofotogrametria S.A., hoje TerraFoto S.A., para O IBC-GERCA (Instituto Brasi- 
leiro do Café, Grupo Executivo de Racionalização da Cafeicultura). As fotos utilizadas estão datadas de junho a setembro de 1972.

Os fotoIndices correspondentes foram utilizados para identificação das fotografias necessárias, a partir da escolha dos locais de amostragem no mapa de solos.

3.6. Material de escritório

Para exame das fotografias foi utilizado estereoscópio de espelhos wild modelo ST-4.

Para medições de comprimento foi utilizado curvimetro.

Outros materiais comuns de desenho foram utilizados quando necessários nas diferentes etapas do trabalho.

\subsection{Seleção das āreas de estudo}

Pela anālise dos mapas pedolögicos de OLIVEIRA et alii (1979, *), foram selecionadas áreas de ocorrência continua das unidades de solo estudadas, independente de subdivisões destas em fases. Sobre as fotografias $1: 60.000$ correspondentes a estas áreas foram traçadas as redes de drenagem superficial.

Seguindo o método de pesquisa lógica sugerido por RABBEN (1960), foram locadas, sobre as redes de drenagem

(*) OLIVEIRA, J.B.; J.R.F. MENK; J.I. BARBIERI; C.I. ROTTA e W.A. TREMOCOLDI. Levantamento pedológico semi-detalhado do Estado de são Paulo - Quadrícula de Araras. Campinas, Instituto Agronômico (não publicado). 
traçadas, as amostras circulares de $10 \mathrm{~km}^{2}$, tomando-se o cuidado de, alêm de conter a maior porcentagem possível de uma mesma unidade pedológica, conter o máximo de canais de drenagem de ordens inferiores segundo a classificação de HORTON (1945) modificada por STRAHLER (1957).

Para maior coincidência das âreas amostradas nas diversas escalas, sempre que possivel, foram usados, pontos identificáveis, nas diferentes coberturas aerofotográficas, para centro das amostras.

\subsection{Obtenção dos mapas de drenagem}

Sob exame estereoscópico das imagens fotográficas das amostras, sem utilização de binocular de aumento adicional, foram traçadas sobre templetos de papel "ultraphan" todos os canais de drenagem superficial, tanto permanentes como temporários, desde que correspondessem a canais já estabelecidos. Foram excluidos os canais oriundos de efeitos erosivos recentes. Também foram locadas as áreas úmidas que contivessem ou não canais de drenagem identíficáveis.

Para evitar sugestionamento e uniformizar a maneira de obtenção dos dados, foram interpretadas inicialmente todas as amostras na escala $1: 60.000 \mathrm{e}$, por último, aquelas na escala 1:25.000.

3.9. Características analisadas dos padrões de drenagem

Nos mapas de drenagem das äreas amostradas foi feita a medição do número e do comprimento total dos canais dạ rede de drenagem.

A partir destes dados e dos valores da área amostral e de seu perímetro, foram calculados os valores de 
frequência de rios, razão de textura, densidade de drenagem e comprimento médio de canais e determinada a classe de textura topográfica.

A frequência de rios foi calculada segundo adaptaçăo por SOUZA (1975) da fôrmula de HORTON (1945), como sendo o número de canais de drenagem por unidade de área da amostra circular.

A razão de textura também foi calculada sequndo SOUZA (1975). que adaptou a definição de SMITH (1950) modificada por FRANÇA (1968) a amostras circulares. Este Indice indica a relação entre o número de canais e o perímetro da amostra circular.

A densidade de drenagem segundo HORTON (1945) e com adaptação de RAY e FISCHER (1960) fornece o valor de comprimento dos canais por unidade de área.

o comprimento médio de canais traduz a relação entre o comprimento total e o número dos canais da rede de drenagem. A análise deste indice segue recomendações de KOFFLER (1976a) e DEMETRIO (1977).

A classe de textura topográfica foi determinada segundo adaptação de FRANÇA (1968) da classificação de SMITH (1950) ao sistema mëtrico.

Descritivamente, os padrões de drenagem foram caracterizados conforme LUEDER (1959), sendo incluido o tipo ou modelo segundo PARVIS (1950) e anomalias segundo RICCI e PETRI (1965).

\subsection{Análiśse estatística}

Os valores obtidos para os índices de drenagem: frequência de rios, razão de textura, densidade de drenagem e comprimento médio dos canais, em função das fotografias em 
diferentes escalas e em função das referências de solo, foram comparadas através do teste não paramētrico de Kruskal-Wallis.

Segundo CAMPOS (1976), sendo um substituto do Teste $F$ do campo paramétrico, o teste Kruskal-Wallis tem a finalidade de averiguar se $\underline{k}$ amostras independentes são provenientes de uma mesma população ou de populações idênticas, ou se provêm de populações distintas.

As hipóteses consideradas para análise dos indices de drenagem das amostras circulares de cada referência de solo foram:

$\mathrm{H}_{0}: E_{1}=E_{2}=E_{3}$ sendo $E_{1}, E_{2}$ e $E_{3}$ as escalas fotográficas utilizadas, respectivamente, $1.60 .000,1: 35.000$ e 1:25:000

$\mathrm{H}_{\mathrm{a}}$ : pelo menos dois tratamentos (escalas fotográficas) diferem entre si

Ao analisar os indices de drenagem obtidos para as amostras circulares atravês de cada uma das três coberturas fotográficas, as hipóteses consideradas foram:

$$
\begin{array}{r}
H_{0}: s_{1}=S_{2}=S_{3}=S_{4}=S_{5} \text { sendo } s_{1}, S_{2}, s_{3}, s_{4} \text { e } s_{5} \text { as } \\
\text { referềnias de solo estu- } \\
\text { dadas (descritas em } 3.1 . \text { ) }
\end{array}
$$

$\mathrm{H}_{\mathrm{a}}$ : pelo menos dois tratamentos (referências de solo) diferem entre si

Quando foi detectada diferença significativa atẻ um nível de 2,58 $(\alpha=0,025)$ no teste de Kruskal-Wallis, foram feitas comparações mūltiplas entre os tratamentos, a fim de quantificar o nível de significância das diferenças existentes. 
Segundo CAMPOS (1976) os processos não paramétricos empregados nas comparações múltiplas, quase sempre, são menos eficientes do que os seus concorrentes do campo paramétrico. Entretanto, foram feitas as comparações mūltiplas, que podem ser encaradas como complementação do teste de Kruskal-Wallis, tendo sido registradas as diferenças existentes até um nỉvel de $10 \%$ de significância $(\alpha=0,100)$. 
40 .

\section{RESULTADOS E DISCUSSÃO}

\subsection{Interpretação das fotografias aéreas}

As reproduções das redes de drenagem das amostras circulares, representativas dos solos estudados, levantadas por fotointerpretação nas fotografias de escala aproximada 1:60.000 estão nas figuras 1 a 5 do apêndice, enquanto que aquelas levantadas nas fotografias de escala aproximada I:35.000 estão nas figuras 6 .a 23 do apêndice e as baseadas nas informações das fotografias de escala aproximada 1:25.000 estão nas figuras 24 a 41 do apêndice.

\subsection{Caracteristicas dimensionais nas amostras}

Nas amostras circulares de $10 \mathrm{~km}^{2}$, cujo perímetro corresponde a $11,21 \mathrm{~km}$, foram feitas contagens do nümero (N) e medições do comprimento total ( $L t$ ) dos canais de drenagem superficial, cujos resultados estão apresentados nos quadros 3 a 4 . Nesses quadros são apresentados também os valores médios das medidas por grupamento de amostras nas referências de solo.

Quanto ao número de canais, observa-se uma ní- 
Quedro 3. Wúmero de canais de drenarem superficial nas amostras circulanes, nas três eacalas fotođ̧ráficas.

\begin{tabular}{|c|c|c|c|c|}
\hline Solo & & Escala & Trotográfica & \\
\hline Referência & Amostra & $1: 60.000$ & $1: 35.000$ & $1: 25.000$ \\
\hline $\begin{array}{c}\mathrm{s}_{1} \text { - Podsólico } \\
\text { Vermelho } \Lambda- \\
\text { narelo }\end{array}$ & $\begin{array}{l}1 \\
2 \\
3\end{array}$ & $\begin{array}{l}61 \\
50 \\
64\end{array}$ & $\begin{array}{l}68 \\
59 \\
66\end{array}$ & $\begin{array}{l}69 \\
69 \\
77\end{array}$ \\
\hline Hédia do $S_{3}$ & & 58,33 & 64,33 & 71,67 \\
\hline $\begin{array}{l}S_{2} \text { - Podzólico } \\
\text { Vermelho A- } \\
\text { maxelo }\end{array}$ & $\begin{array}{l}4 \\
5 \\
6 \\
7\end{array}$ & $\begin{array}{l}19 \\
35 \\
38 \\
66\end{array}$ & $\begin{array}{l}27 \\
51 \\
64 \\
75\end{array}$ & $\begin{array}{r}36 \\
55 \\
60 \\
100\end{array}$ \\
\hline Hédia do $S_{2}$ & & 39,50 & 54,25 & 62,75 \\
\hline $\begin{array}{l}\mathrm{S}_{3} \text { - Iatossolo } \\
\text { Vermelho A- } \\
\text { nlarelo }\end{array}$ & $\begin{array}{r}8 \\
9 \\
10 \\
11\end{array}$ & $\begin{array}{l}4 \\
6 \\
6 \\
7\end{array}$ & $\begin{array}{l}5 \\
7 \\
8 \\
6\end{array}$ & $\begin{array}{r}5 \\
10 \\
9 \\
6\end{array}$ \\
\hline Média do $S_{3}$ & & 5,75 & 6,50 & 7,50 \\
\hline $\begin{array}{l}\mathrm{S}_{4} \text { - Tatossolo } \\
\text { Vermelho } \Lambda- \\
\text { marelo }\end{array}$ & $\begin{array}{l}12 \\
13 \\
14 \\
15\end{array}$ & $\begin{array}{l}5 \\
6 \\
4 \\
8\end{array}$ & $\begin{array}{l}6 \\
5 \\
4 \\
9\end{array}$ & $\begin{array}{r}6 \\
6 \\
4 \\
13\end{array}$ \\
\hline Média do $\mathrm{S}_{4}$ & & 5,75 & 6,00 & 7,25 \\
\hline$S_{5} \underset{\text { Roxo }}{- \text { Iotossolo }}$ & $\begin{array}{l}16 \\
17 \\
18\end{array}$ & $\begin{array}{r}10 \\
11 \\
6\end{array}$ & $\begin{array}{r}15 \\
13 \\
6\end{array}$ & $\begin{array}{r}10 \\
12 \\
7\end{array}$ \\
\hline 訨édia do $\mathrm{S}_{5}$ & & 9,00 & 11,33 & 9,67 \\
\hline
\end{tabular}


Quadro 4. Comprimerto total dor caneis de dronagem superficial, em guilome tros, nas anostras circulares, nos três escaios fotofráüicas.

\begin{tabular}{|c|c|c|c|c|}
\hline Solo & & Escala & Fotográfica & \\
\hline Referência & Amostra & $1: 60.000$ & $1: 35.000$ & $1: 25.000$ \\
\hline $\begin{array}{l}S_{1} \text { - Podzólico } \\
\text { Vermelho A- } \\
\text { narelo }\end{array}$ & $\begin{array}{l}1 \\
2 \\
3\end{array}$ & $\begin{array}{l}27,780 \\
25,620 \\
27,950\end{array}$ & $\begin{array}{l}30,450 \\
26,635 \\
27,335\end{array}$ & $\begin{array}{l}31,800 \\
29,700 \\
29,600\end{array}$ \\
\hline Méaia do $S_{1}$ & & 27,120 & 28,740 & 30,367 \\
\hline $\begin{array}{l}: 2 \text { - Podzölico } \\
\text { Vernelho A- } \\
\text { marelo }\end{array}$ & $\begin{array}{l}4 \\
5 \\
6 \\
7\end{array}$ & $\begin{array}{l}13,620 \\
13,960 \\
24,120 \\
27,480\end{array}$ & $\begin{array}{l}23,170 \\
20,720 \\
24,570 \\
27,125\end{array}$ & $\begin{array}{l}16,300 \\
21,500 \\
25,350 \\
31,000\end{array}$ \\
\hline Mécila do $\mathrm{S}_{2}$ & & $21,0,5$ & 23,996 & 23,512 \\
\hline $\begin{array}{l}\mathrm{S}_{3} \text { - Iatossolo } \\
\text { VermeIho A- } \\
\text { marelo } \\
\text { i.iédia do } \mathrm{S}_{3}\end{array}$ & $\begin{array}{r}8 \\
10 \\
11\end{array}$ & $\begin{array}{l}6,840 \\
6,000 \\
5,540 \\
8,320 \\
6,325\end{array}$ & $\begin{array}{l}7,000 \\
6,300 \\
7,420 \\
7,395 \\
7,026\end{array}$ & $\begin{array}{l}6,525 \\
6,925 \\
7,000 \\
7,450 \\
6,975\end{array}$ \\
\hline $\begin{array}{c}S_{4} \text { - Iatossolo } \\
\text { Vermelho } \Lambda \text { - } \\
\text { narelo }\end{array}$ & $\begin{array}{l}12 \\
13 \\
14 \\
15\end{array}$ & $\begin{array}{l}6,720 \\
7,800 \\
5,700 \\
7,800\end{array}$ & $\begin{array}{l}7,350 \\
7,525 \\
5,460 \\
7,245\end{array}$ & $\begin{array}{l}7,750 \\
7,300 \\
5,325 \\
8,100\end{array}$ \\
\hline Média do $\mathrm{S}_{4}$ & & 7,005 & 6,895 & 7,244 \\
\hline $\mathrm{S}_{5}$ - Iatossolo & $\begin{array}{l}16 \\
17 \\
18\end{array}$ & $\begin{array}{r}7,980 \\
10,440 \\
10,260\end{array}$ & $\begin{array}{r}7,735 \\
10,850 \\
10,045\end{array}$ & $\begin{array}{r}7,725 \\
10,975 \\
11,075\end{array}$ \\
\hline Média do $S_{5}$ & & 9,560 & 9,543 & 9,925 \\
\hline
\end{tabular}


tida diferenciação entre as amostras representativas de solos podzólicos (referências $S_{1}$ e $S_{2}$ ) e aquelas de latossolos (referênclas $s_{3}, s_{4}$ e $s_{5}$.

Dentre os latossolos, percebe-se valores semelhantes para as referências de Latossolo Vermelho Amarelo correspondendo a 55\%, em mêdia, dos valores obtidos para o Latossolo Roxo.

Entre as amostras representativas dos solos podzólicos, tambëm são notadas diferenças; os valores médios para $S_{1}$ correspondem a 115 a $145 \%$ daqueles para $S_{2}$ nas diferentes escalas.

Quanto ao aspecto de variação dos valores para o número de canais; em cada referência de solo, medidos em fotografias nas diferentes escalas, observa-se que há aumęnto no sentido da menor escala para a maior, sendo sensível no caso dos solos podzólicos, quando ocorreu até 30\% de aumento. Somente nas amostras representativas do Latossolo Roxo ocorreu uma diminuição no nümero de canais medidos, ao mudar da escala 1:35.000 para 1:25.000, embora no outro intervalo de mudança de escalas tenha ocorrido pequeno aumento, como nos outros latossolos.

Os dados obtidos para comprimento total dos canais seguem as mesmas tendências daqueles obtidos para o número de canais. Assim, há nítida distinção entre os dados dos solos podzólicos e dos latossolos, tendo os Latossolos Vermelho Amarelo apresentado valores semelhantes entre si e pouco inferiores aos do Latossolo Roxo.

Houve também tendência de aumento nos dados de comprimento total dos canais no sentido das medições feitas nas fotografias de escala menor para aquelas feitas nas de escala maior. Entretanto, estes aumentos foram de valor absoluto reduzido.

Estes dados estão de acordo com as observações 
de LUEDER (1959) sobre o desenvolvimento do padrão de drenagem em função das características diferenciais de capacidade de infiltração, permeabilidade e textura dos materiais presentes na ārea. Pela descrição suscinta das unidades de solo que ocorrem na área, segundo OLIVEIRA et alii (1979, *), percebe-se a tendência de característica de boa drenagem para os Latossolos Vermelho Amarelo. Dentre os solos podzólicos, os da referência $S_{1}$, originados principalmente de gnaisses, enquanto que os da referência $\mathrm{S}_{2}$ em sua maioria provenientes de arenitos, são os que tendem a apresentar menor relação infiltração/deflúvio. Observa-se que quanto menor esta relação, mais densa tende a ser a rede de drenagem, com maior número đe canais.

A variação encontrada para o número de canais com material fotogräfico de escalas diferentes, concorda'com os resultados obtidos por KOFFLER (1976a), que atribui tal efeito ao maior detalhe oferecido pela fotografias em escala maior. Este efeito é secundário quando a rede de drenagem é menos densa e com canais mais longos, como no caso do latossolos.

As mesmas considerações são válidas para a ocorrência de variações no comprimento dos canais de drenagem de amostras representativas de solos diferentes. Neste caso, a influência de variação de escala fotográfica se torna menos notável, principalmente nos latossolos.

(*) OLIVEIRA, J.B.; J.R.F. MENK; J.L. BARBIERI; C.L. ROTTA e W.A. TREMOCOLDI. Levantamento pedológico semi-detaIhado do Estado de São Paulo - Quadrícula de Araras. Campinas, Instituto Agronômico (não publicado). 


\subsection{Indices de drenagem}

\subsubsection{Frequência de rios}

Os valores calculados para frequência de rios nas amostras circulares $(F C=N / A$ ) com as fotografias em três escalas, e seus valores mêdios por refêrência de solos são apresentados no quadro 5 . 0 quadro 6 resume os resultados obtidos pela aplicação do teste de Kruskal-Wallis, quando foi estipulada significância de diferença até nível de 5\%, e pelas comparações múltiplas que são mostradas entre os tratamentos diferentes, até nível de $10 \%$ de significância.

E notável a distinção entre os solos podzólicos e os latossolos pelos valores deste indice.

O teste de Kruskal-Wallis também acusa a ocorrência de diferenças entre as referências de solo, da ordem de $1,0 \%$ de significância nas escalas $E_{1}(1: 60.000)$ e $E_{2}$ $(1: 35.000)$ e de $2,5 \%$ na escala $E_{3}(1: 25.000)$. Pelas comparações múltiplas, ocorrem diferenças entre $\circ S_{1}$ e $\circ S_{3}$ num nivel de $7,8 \%$ de significância e entre $\circ \mathrm{s}_{1}$ e $\circ \mathrm{s}_{4} \operatorname{com} 6,0 \%$ de significância, dentro da escala $E_{1}(1: 60.000)$. Na escala $E_{2}$ (1:35.000) só foi detectado diferença significativa entre o $s_{1}$ e $\circ s_{4}$, ao nível de $5,8 \%$. Com os dados obtidos nas fotografias de escala $E_{3}(1: 25.000)$, há diferença entre $\circ s_{1}$ e $\circ$ $\mathrm{S}_{4}$ com $7,0 \%$ de significância.

Na comparação dos dados obtidos nas três escalas fotográficas, só ocorreu diferença, ao nível de 2,5\% de distinção, para a referência de solo $\mathrm{S}_{1}$ : $\mathrm{E}$, neste caso, a diferença foi atribuida às escalas $E_{1}$ e $E_{3}$, a um nível de $2,9 \%$ de significância.

KOFFLER (1976a) e DEMETRIO (1977), em trábalhos que também compararam escalas fotográficas, obtiveram resultados com as mesmas tendências do presente, para $\circ$ indice frequência de rios. 
Quadro5. Frequência de rios nas amostras circulares, nas três escalas foto gráficas.

\begin{tabular}{|c|c|c|c|c|}
\hline Solo & & Escala & Fotográfica & \\
\hline Referência & Amostra & $1: 60.000$ & $1: 35.000$ & $1: 25.000$ \\
\hline $\begin{array}{l}\mathrm{S}_{1} \text { - Podzólico } \\
\text { Vermelho } \mathrm{A}- \\
\text { marelo }\end{array}$ & $\begin{array}{l}1 \\
2 \\
3\end{array}$ & $\begin{array}{l}6,1 \\
5,0 \\
6,4\end{array}$ & $\begin{array}{l}6,8 \\
5,9 \\
6,6\end{array}$ & $\begin{array}{l}6,9 \\
6,9 \\
7,7\end{array}$ \\
\hline Média do $S_{1}$ & & 5,833 & 6,433 & 7,167 \\
\hline $\begin{array}{l}\mathrm{S}_{2} \text { - Podzolico } \\
\text { Vexmelho A- } \\
\text { naxelo }\end{array}$ & $\begin{array}{l}4 \\
5 \\
6 \\
7\end{array}$ & $\begin{array}{l}1,9 \\
3,5 \\
3,8 \\
6,6\end{array}$ & $\begin{array}{l}2,7 \\
5,7 \\
6,4 \\
7,5\end{array}$ & $\begin{array}{r}3,6 \\
5,5 \\
6,0 \\
10,0\end{array}$ \\
\hline Lédia do $\mathrm{S}_{2}$ & & 3,950 & 5,425 & 6,275 \\
\hline $\begin{array}{l}S_{3} \text { - Iatossolo } \\
\text { Vermelho } \mathrm{A}- \\
\text { marelo }\end{array}$ & $\begin{array}{r}8 \\
9 \\
10 \\
11\end{array}$ & $\begin{array}{l}0,4 \\
0,6 \\
0,6 \\
0,7\end{array}$ & $\begin{array}{l}0,5 \\
0,7 \\
0,8 \\
0,6\end{array}$ & $\begin{array}{l}0,5 \\
1,0 \\
0,9 \\
0,6\end{array}$ \\
\hline Milédia do $S_{3}$ & & 0,575 & 0,650 & 0,750 \\
\hline $\begin{array}{c}\mathrm{S}_{4} \text { - Iatossolo } \\
\text { marmelho A- } \\
\text { marelo }\end{array}$ & $\begin{array}{l}12 \\
13 \\
14 \\
15\end{array}$ & $\begin{array}{l}0,5 \\
0,6 \\
0,4 \\
0,8\end{array}$ & $\begin{array}{l}0,6 \\
0,5 \\
0,4 \\
0,9\end{array}$ & $\begin{array}{l}0,6 \\
0,6 \\
0,4 \\
1,3\end{array}$ \\
\hline Média do $\mathrm{S}_{4}$ & & 0,575 & 0,600 & 0,725 \\
\hline$S_{5}$ - Iotossolo & $\begin{array}{l}16 \\
17 \\
18\end{array}$ & $\begin{array}{l}1,0 \\
1,7 \\
0,6\end{array}$ & $\begin{array}{l}1,5 \\
1,3 \\
0,6\end{array}$ & $\begin{array}{l}1,0 \\
1,2 \\
0,7\end{array}$ \\
\hline Média do $S_{5}$ & & 0,900 & 1,133 & 0,967 \\
\hline
\end{tabular}


Quadro 6. Resultados do teste de Kruskal-Wallis envolvendo as escalas fotográficas $\left(E_{1}, E_{2}\right.$ e $\left.E_{3}\right)$ e as referências de solo $\left(\mathrm{S}_{1}, \mathrm{~S}_{2}, \mathrm{~S}_{3}, \mathrm{~S}_{4}, \mathrm{~S}_{5}\right)$ e das comparações múltiplas com diferença significatica até o nível de $10 \%$ para o índice frequência de rios

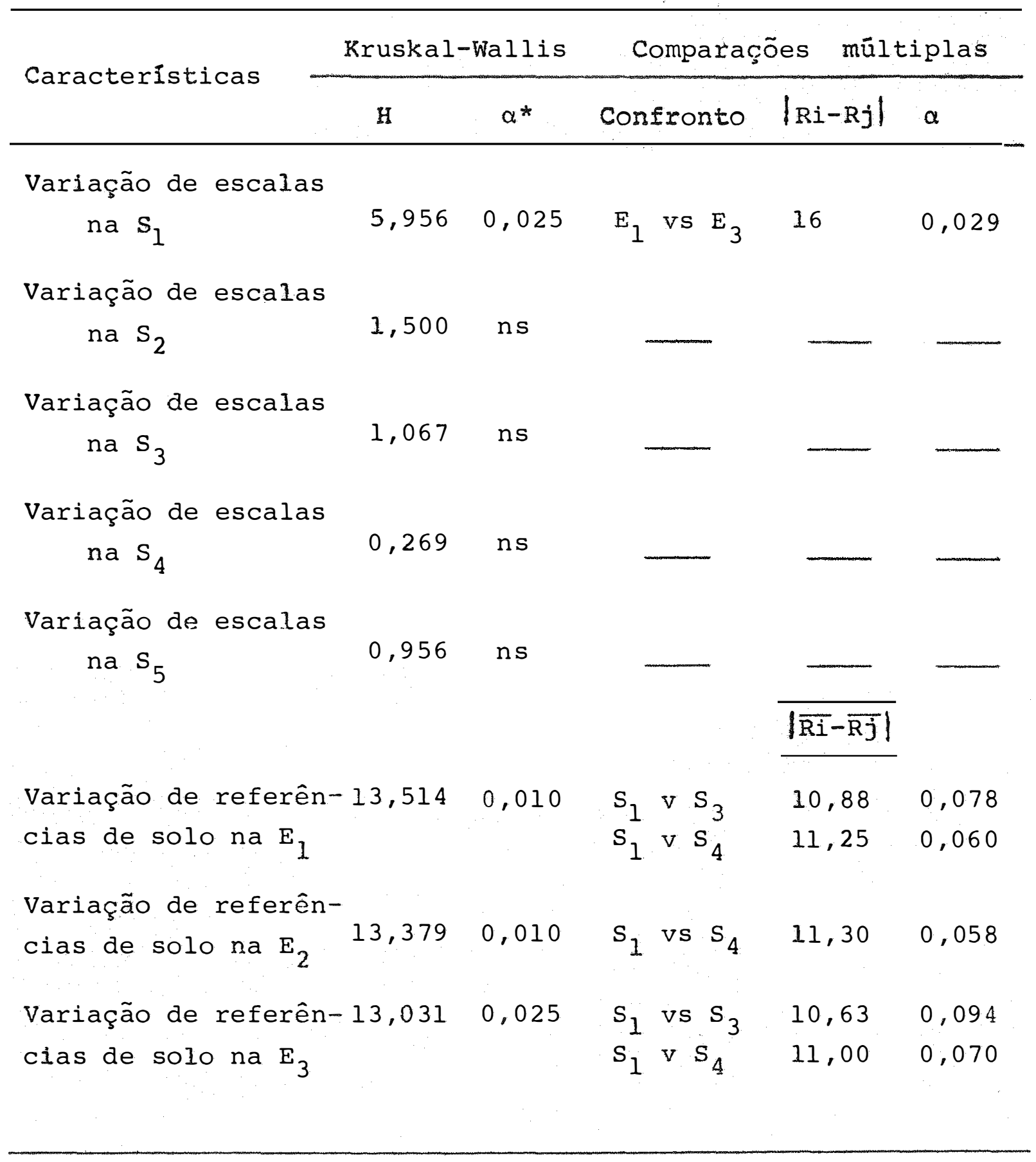

* Limite máximo de significância: 5\% 


\subsubsection{Razão de textura}

O quadro 7 apresenta os valores calculados para o Indice razão de textura nas amostras circulares $(\mathrm{TC}=\mathrm{N} / \mathrm{P})$, com as fotografias nas escalas estudadas, bem como os valores médios por grupamento das amostras nas cinco referêncilas de solo.

Cabe observar que os valores de Tc tambëm podem ser obtidos pela divisão dos valores de FC por 1,121, que corresponde ao valor da relação existente entre o perímetro e a área (A) das amostras circulares utilizadas.

Aplicou-se a estes resultados o teste de Kruskal- Wallis e, quando houvesse diferença com significância até o nível de 5\%, o teste das comparações mültiplas, e preparou-se o demonstrativo no quadro 8. Observa-se que as comparações mültiplas demonstradas são somente aquelas em que a diferença fosse significativa até o nivel de 10\%.

Os mesmos comentários tecidos a respeito das variações ocorridas para o Indice frequência de rios são vãlidos para este indice.

Devido à existência de relação fiza entre perímetro e área do círculo, torna-se desnecessārio a análíse de dois parâmetros que relacionam o nümero de canais de drenagem com cada uma destas dimensões da amostra circular. Considera- se preferivel, se a amostragem utilizada for através de circulos de mesma área, a análise somente da razão de textura segundo proposição de SMITH (1950) com modificação de FRANÇA (1968), por permitir a classificação do padrão de drenagem conforme a textura topográfica da maneira proposta por estes dois autores. Por outro lado, segundo KOFFLER (1976b), o Indice razão de textura não deve ser aplicado para comparar padrões de drenagem em amostras de dimensões variadas, caso em que seria mais recomendavel o Índice frequência de rios proposto por HORTON (1945). 
49.

Quadro 7. Razão de textura nes arostras circulares, nas três escalas fotoungías.

\begin{tabular}{|c|c|c|c|c|}
\hline Solo & & Escala & Fotográti & \\
\hline Referência & Amostra & $1: 60.000$ & $1: 35.000$ & $1: 25.000$ \\
\hline $\begin{array}{l}S_{1} \text { - Podzólico } \\
\text { Vermelho A- } \\
\text { narelo }\end{array}$ & $\begin{array}{l}\frac{1}{2} \\
3\end{array}$ & $\begin{array}{l}5,42 \\
4,60 \\
5,709\end{array}$ & $\begin{array}{l}5,056 \\
5.263 \\
5.233\end{array}$ & $\begin{array}{l}6,155 \\
6,155 \\
6,869\end{array}$ \\
\hline Méaia do $\mathfrak{S}_{1}$ & & 5,204 & 5.730 & 6,393 \\
\hline $\begin{array}{l}\mathrm{S}_{2} \text { - Podzólico } \\
\text { Vermelho } \mathrm{A}- \\
\text { marelo }\end{array}$ & $\begin{array}{l}f_{r} \\
5 \\
6 \\
7\end{array}$ & $\begin{array}{l}1,695 \\
3,122 \\
3,300 \\
5,303\end{array}$ & $\begin{array}{l}2,409 \\
6,549 \\
5,709 \\
6,690\end{array}$ & $\begin{array}{l}3,211 \\
4,306 \\
5,352 \\
3,921\end{array}$ \\
\hline Widia do $S_{2}$ & & 3,524 & 4.339 & 5,598 \\
\hline $\begin{array}{l}S_{3} \text { - Iatossolo } \\
\text { Vermelho } A= \\
\text { marelo }\end{array}$ & $\begin{array}{r}8 \\
9 \\
10 \\
11\end{array}$ & $\begin{array}{l}0,357 \\
0,535 \\
0,535 \\
0,524\end{array}$ & $\begin{array}{l}0,446 \\
0,624 \\
0,734 \\
0,535\end{array}$ & $\begin{array}{l}0,446 \\
0,892 \\
0,303 \\
0,535\end{array}$ \\
\hline Média do $\mathrm{S}_{3}$ & & 0,513 & 0,580 & 0,669 \\
\hline $\begin{array}{l}S_{4} \text { - Iotossolo } \\
\text { Vermelho } \Lambda- \\
\text { marelo }\end{array}$ & $\begin{array}{l}12 \\
13 \\
14 \\
15\end{array}$ & $\begin{array}{l}0,445 \\
0,535 \\
0,357 \\
0,714\end{array}$ & $\begin{array}{l}0,535 \\
0,4.65 \\
0,357 \\
0,203\end{array}$ & $\begin{array}{l}0,535 \\
0,535 \\
0,357 \\
1,960\end{array}$ \\
\hline Média do $S_{4}$ & & 0,513 & 0.535 & 0,647 \\
\hline $\mathfrak{S}_{5}$ - Ratosisolo & $\begin{array}{l}16 \\
17 \\
18\end{array}$ & $\begin{array}{l}0,392 \\
0,991 \\
0,535\end{array}$ & $\begin{array}{l}1,338 \\
1,160 \\
0.535\end{array}$ & $\begin{array}{l}0,892 \\
1,070 \\
0,624\end{array}$ \\
\hline Média do $S_{5}$ & & 0,503 & 18011 & 0,852 \\
\hline
\end{tabular}


50.

Quadro 8. Resultados do teste de Kruskal-Wallis envolvendo as escalas fotográficas $\left(E_{1}, E_{2}\right.$ e $\left.E_{3}\right)$ e as referências de solo $\left(\mathrm{S}_{1}, \mathrm{~S}_{2}, \mathrm{~S}_{3}, \mathrm{~S}_{4}, \mathrm{~S}_{5}\right)$ e das comparações múltiplas com diferença significatica atē o nivel de $10 \%$ para o indice razão de textura

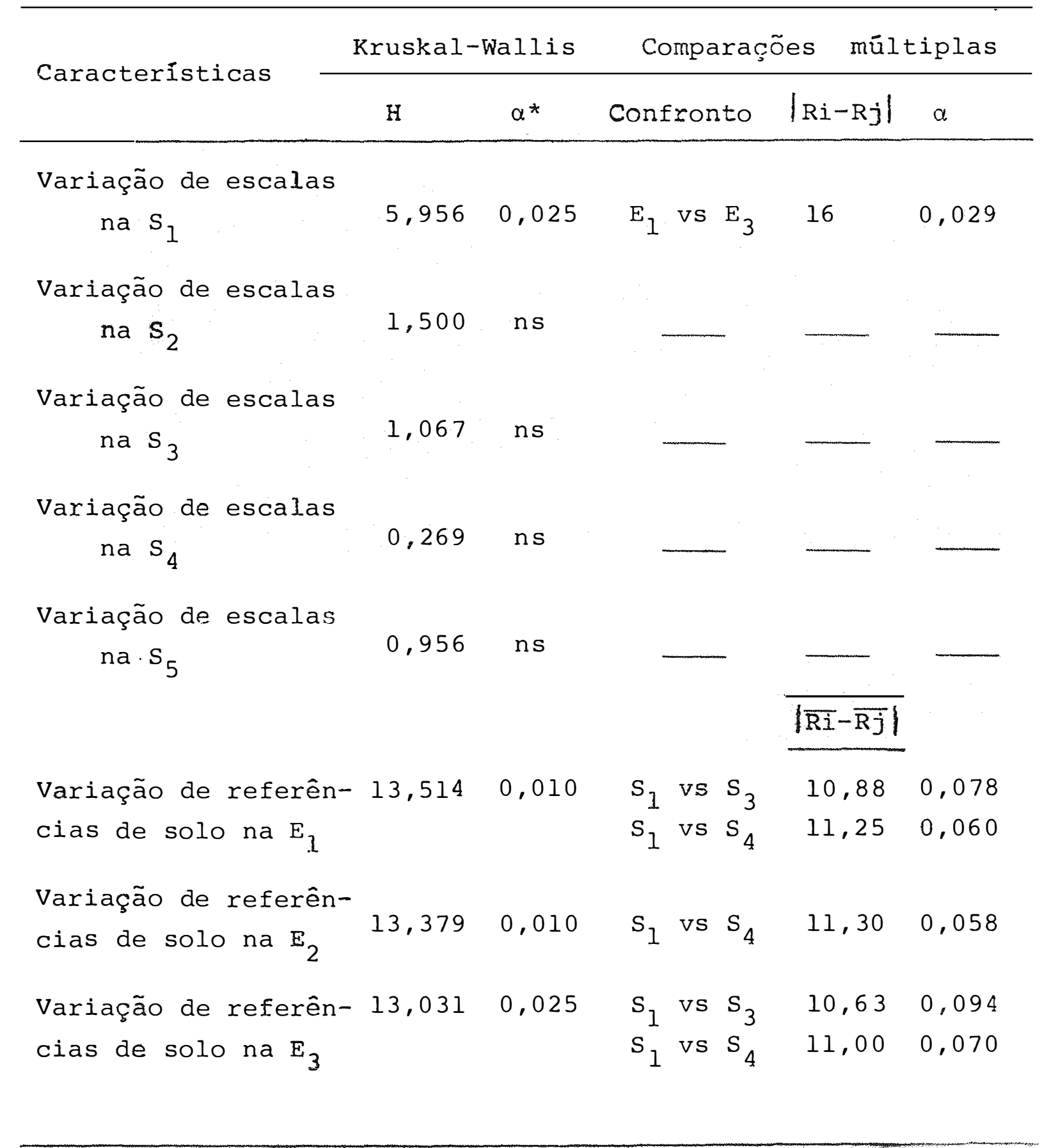

* Limite máximo de significância: 5\% 


\subsubsection{Densidade de drenagem}

Os valores de densidade de drenagem das amostras circulares $(\mathrm{DC}=\mathrm{Lt} / \mathrm{A})$ em material fotogräfico nas três escalas foram calculados e estão reproduzidos no quadro 9, que também fornece os valores médios por referência de solo.

O quadro 10 demonstra os resultados obtidos pela aplicação dos testes de Kruskal-Wallis e das comparações múltiplas. Foram consideradas diferenças significativas no teste de Kruskal-Wallis, aquelas até nível de 5\% de significância. Estão apresentadas apenas as comparações múltiplas com diferença significativa atê nîvel de $10 \%$

Os valores obtidos distinguem os solos podzólicos dos latossolos, porëm estas diferenciações sö têm significância, até o nível limite considerado, entre o $\mathrm{s}_{1} \mathrm{e} \circ \mathrm{s}_{3}$ nas três escalas, e entre $\circ \mathrm{S}_{1}$ e $\circ \mathrm{S}_{4}$ nas duas escalas menores.

Não houveram diferenças significativas entre os valores obtidos para cada referência de solo nas diversas escalas estudadas.

A aplicação deste Índice para estudos litológicos por RAY e FISCHER (1960) foi estendida com sucesso por FRANÇA (1968) para interpretação pedológica; posteriormente, diversos autores como MARCHETTI (1969), FADEL (1972), LEÄO (1972), VASQUES FILHO (1972), KOFFLER (1976a; 1976b), CARVALHO (1977), DEMÊTRIO (1977), FREIRE (1977) e SILVA (1977) verificaram a grande eficiência deste Indice para diferenciação de unidades pedológicas. Os resultados obtidos no presente trabalho discordam em parte das conclusões desses autores.

4.3.4. Comprimento médio dos canais de drenagem superficial

O quadro 11 contém os valores calculados para 
Quadro 9. Densidade de arenasen nas anostras circulares, nas três escalas foto járicas.

\begin{tabular}{|c|c|c|c|c|}
\hline Solo & & Escala & Totográfica & \\
\hline Referência & Amostra & $1: 60.000$ & $1: 35.000$ & $1: 25.000$ \\
\hline $\begin{array}{l}\Xi_{1} \text { - Podsólico } \\
\text { Verrielho } A= \\
\text { narelo }\end{array}$ & $\begin{array}{l}1 \\
2 \\
3\end{array}$ & $\begin{array}{l}2,778 \\
2,562 \\
2,796\end{array}$ & $\begin{array}{l}3,045 \\
2,653 \\
2,733\end{array}$ & $\begin{array}{l}3,180 \\
2,970 \\
2,960\end{array}$ \\
\hline Néaia do $s_{1}$ & & 2,712 & 2,824 & 3,037 \\
\hline $\begin{array}{l}S_{2} \text { Podzólico } \\
\text { Vermelho } A- \\
\text { narelo }\end{array}$ & $\begin{array}{l}4 \\
5 \\
6 \\
7\end{array}$ & $\begin{array}{l}1,362 \\
1,896 \\
2,412 \\
2,748\end{array}$ & $\begin{array}{l}2,317 \\
2,072 \\
2,457 \\
2,712\end{array}$ & $\begin{array}{l}1,630 \\
2,140 \\
2,535 \\
3,100\end{array}$ \\
\hline Médie do $\mathrm{S}_{2}$ & & 2,104 & 2.389 & 2,351 \\
\hline $\begin{array}{l}\text { \$z - Latossolo } \\
\text { Vermelho A- } \\
\text { marelo }\end{array}$ & $\begin{array}{r}8 \\
9 \\
10 \\
1.1\end{array}$ & $\begin{array}{l}0,684 \\
0,600 \\
0,564 \\
0,882\end{array}$ & $\begin{array}{l}0.700 \\
0.630 \\
0,742 \\
0.738\end{array}$ & $\begin{array}{l}0,652 \\
0,692 \\
0,700 \\
0,745\end{array}$ \\
\hline Média do $S_{z}$ & & 0,682 & 0,702 & 0,697 \\
\hline $\begin{array}{l}S_{4} \text { - Totossolo } \\
\text { VermeIho } 1- \\
\text { marelo }\end{array}$ & $\begin{array}{l}12 \\
13 \\
14 \\
1.5\end{array}$ & $\begin{array}{l}0,672 \\
0,780 \\
0,570 \\
0,730\end{array}$ & $\begin{array}{l}0,735 \\
0,752 \\
0,545 \\
0,724\end{array}$ & $\begin{array}{l}0,775 \\
0,780 \\
0,532 \\
0,810\end{array}$ \\
\hline Mérila do $S_{4}$ & & 0,700 & 0,689 & 0,724 \\
\hline$S_{5} \underset{\text { Roxo }}{- \text { Iotossolo }}$ & $\begin{array}{l}16 \\
17 \\
18\end{array}$ & $\begin{array}{l}0,738 \\
1,044 \\
1,026\end{array}$ & $\begin{array}{l}0,773 \\
1,085 \\
2,004\end{array}$ & $\begin{array}{l}0,772 \\
1,097 \\
1,107\end{array}$ \\
\hline Média do. $S_{5}$ & & 0,956 & 0,954 & 0,992 \\
\hline
\end{tabular}


Quadro 10. Resultados do teste de Kruskal-Wallis envolvendo as escalas fotogräficas $\left(E_{1}, E_{2}\right.$ e $\left.E_{3}\right)$ e as referências de solo $\left(S_{1}, S_{2}, S_{3}, S_{4}, S_{5}\right)$ e das comparações múltiplas com diferença significatica até o nivel de $10 \%$ para 0 indice densidade de drenagem

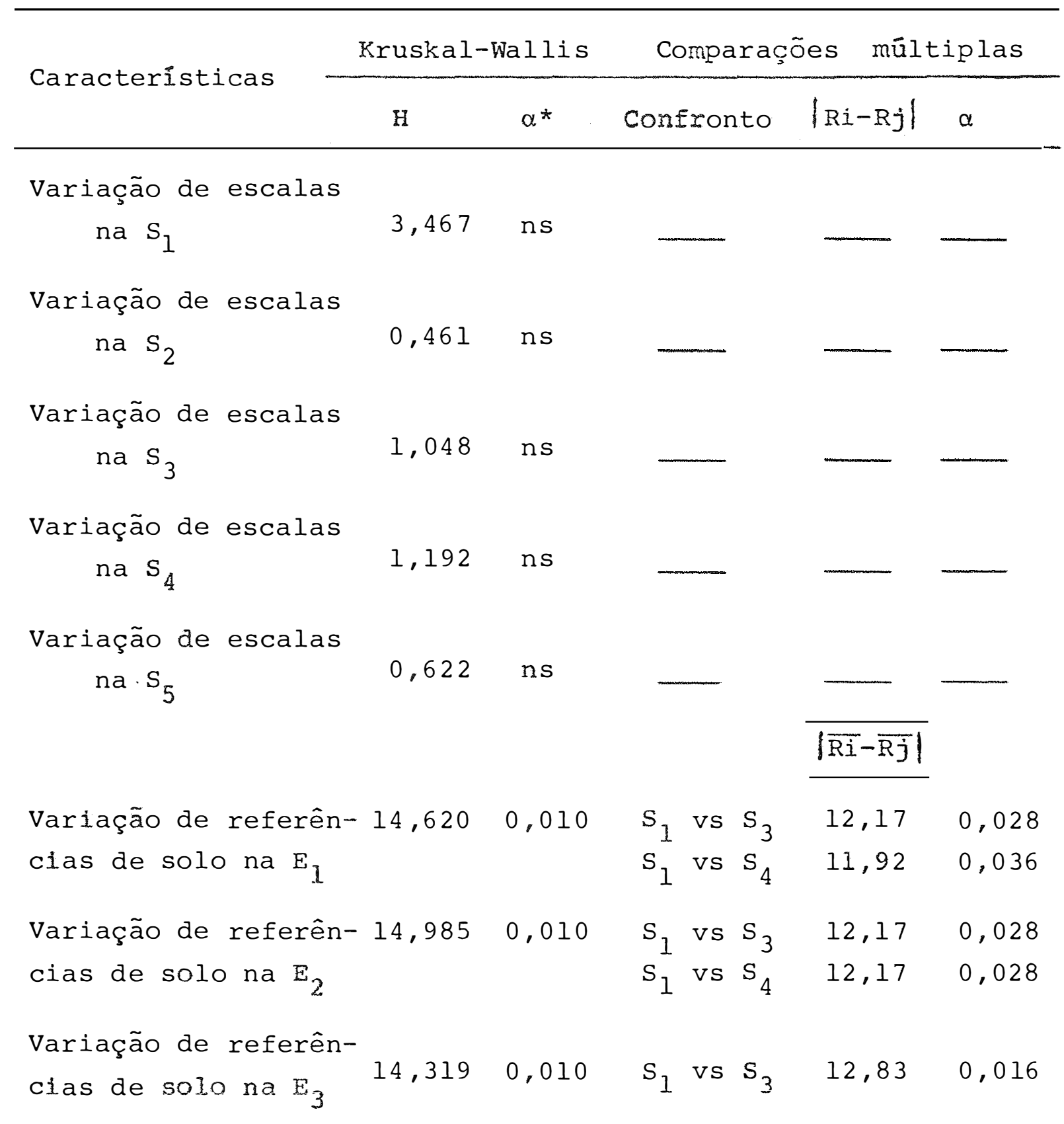

* Limite máximo de significância: 5\% 
Quadro 11. Comprimento médio dos canais de drenagem superficial, en quilômetros, nas amostras circulares, nas tres escalas cotográricas.

\begin{tabular}{|c|c|c|c|c|}
\hline Solo & & Escala & Totográfica & \\
\hline Referência & Amostra & $1: 60.000$ & $1: 35.000$ & $1: 25.000$ \\
\hline $\begin{array}{l}\mathrm{s}_{1} \text { - Podélico } \\
\text { Vemelho A- } \\
\text { marelo }\end{array}$ & $\begin{array}{l}1 \\
2 \\
3\end{array}$ & $\begin{array}{l}0,455 \\
0,512 \\
0,437\end{array}$ & $\begin{array}{l}0,448 \\
0,451 \\
0,414\end{array}$ & $\begin{array}{l}0,461 \\
0,430 \\
0,384\end{array}$ \\
\hline Média do $S_{1}$ & & $0,4 \in 8$ & 0,437 & 0,425 \\
\hline $\begin{array}{l}S_{2} \text { - Podzólico } \\
\text { Vermelho A- } \\
\text { maxelo }\end{array}$ & $\begin{array}{l}4 \\
5 \\
6 \\
7\end{array}$ & $\begin{array}{l}0,717 \\
0,542 \\
0,635 \\
0,416\end{array}$ & $\begin{array}{l}0,853 \\
0,406 \\
0,384 \\
0,362\end{array}$ & $\begin{array}{l}0,453 \\
0,389 \\
0,422 \\
0,310\end{array}$ \\
\hline Média do $\mathrm{S}_{2}$ & & 0,577 & 0,502 & 0,393 \\
\hline $\begin{array}{c}\mathrm{S}_{3} \text { - } \text { Tatossolo } \\
\text { nermelho A- } \\
\text { narelo }\end{array}$ & $\begin{array}{r}8 \\
9 \\
10 \\
11\end{array}$ & $\begin{array}{l}1,710 \\
1,000 \\
0,940 \\
1,260\end{array}$ & $\begin{array}{l}1,400 \\
0,900 \\
0,927 \\
1,231\end{array}$ & $\begin{array}{l}1,305 \\
0,692 \\
0,773 \\
1,242\end{array}$ \\
\hline Média do $S_{3}$ & & 1,227 & 1,114 & 1,004 \\
\hline $\begin{array}{l}\mathrm{S}_{4} \text { - Iatossolo } \\
\text { Vemelho A- } \\
\text { marelo }\end{array}$ & $\begin{array}{l}12 \\
13 \\
14 \\
15\end{array}$ & $\begin{array}{l}1,344 \\
1,300 \\
1,425 \\
0,975\end{array}$ & $\begin{array}{l}1,225 \\
1,505 \\
1,355 \\
0,205\end{array}$ & $\begin{array}{l}1,292 \\
1,300 \\
1,331 \\
0,623\end{array}$ \\
\hline Média do $\mathrm{S}_{4}$ & & 1,261 & 1,225 & 1,136 \\
\hline$S_{5}$ - Roxo & $\begin{array}{l}16 \\
17 \\
18\end{array}$ & $\begin{array}{l}0,798 \\
0,949 \\
1,710\end{array}$ & $\begin{array}{l}0,515 \\
0,855 \\
1,674\end{array}$ & $\begin{array}{l}0,772 \\
0,915 \\
1,532\end{array}$ \\
\hline Móàda do $\mathfrak{S}_{5}$ & & 1,152 & 1,008 & 1,090 \\
\hline
\end{tabular}


comprimento médio dos canais de drenagem superficiall $(\operatorname{Lm}=L t / N)$ nas amostras circulares feitas sobre fotografias nas três escalas estudadas. Neste quadro estão tambēm os valores médios deste Indice, por referência de solo.

Pela aplicação dos testes não paramétricos de Kruskal-Wallis e de comparaçöes mültiplas, chegou-se aos valores apresentados no quadro 12 . Foram fixados os limites de significância das diferenças analisadas, o nível de 5응 no teste de Kruskal-Wallis e de 10 용 nas comparaçöes múltiplas ; só estão demonstradas as comparações mūltiplas de diferenças significantes.

observa-se que os valores obtidos para os solos podzólicos são no mäximo 50 \% dos valores obtidos para os latossolos, tendo sido acusadas diferenças significativas pelo teste de Kruskal-Wallis. Atravēs das comparações mültiplàs, só foi localizada diferença, até o nível limite de significância estipulado, entre $\circ S_{1}$ e $S_{4}$ na escala 1:60.000.

Não foi observado efeito da variação de escala fotogrăfica na obtenção deste îndice nas diversas referências de solo.

O estudo do comprimento médio do canais, conforme sugestöes de KOFFLER (1976a) e DEMETRIO (1977), não apresentou resultados tão significaticos como os outros três analisados. Considerando que este indice corresponde à relação entre outros dois (densidade de drenagem e frequência de rios) não se recomenda sua inclusão entre os indices caracterizadores de padrão de drenagem em amostras circulares.

\subsection{Textura topogräfica}

Os valores mëdios da razão de textura das amostras circulares (TC) permitiram, segundo parâmetros de SMITH (1950) modificados por FRANÇA (1968) para o sistema mëtrico, 
56.

Quadro 12. Resultados do teste de Kruskal-Wallis envolvendo as escalas fotográficas $\left(E_{1}, E_{2}\right.$ e $\left.E_{3}\right)$ e as referências de solo $\left(S_{1}, S_{2}, S_{3}, S_{4}, S_{5}\right)$ e das comparações mültiplas com diferença significatica até o nível de $10 \%$ para o índice comprimento médio dos canais de drenagem superficial

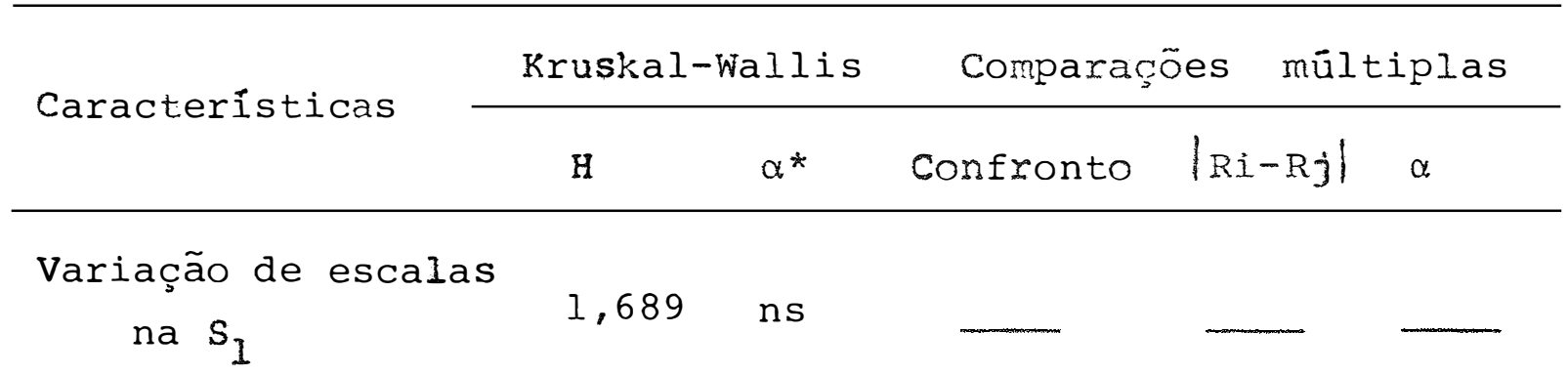

Variação de escalas

na $\mathrm{S}_{2} \quad 2,923$ ns

Variação de escalas

na $\mathrm{S}_{3} \quad 1,192$ ns

Variação de escalas na $\mathrm{S}_{4}$

$0,894 \quad$ ns

Variação de escalas

$\mathrm{na} \cdot \mathrm{S}_{5} \quad 0,622 \mathrm{~ns}$

Variàção de referên-

cias de solo na $E_{1} \quad 12,628 \quad 0,025 \quad S_{1}$ vs $S_{4} \quad 11,00 \quad 0,070$

Variação de referên-

cias de solo na $\mathrm{E}_{2} \ldots 10,678 \quad 0,050$

Variação de referên-

cias de solo $\mathrm{na}_{3} \quad 12,365 \quad 0,025$

* Iimite máximo de significância: 5\% 
classificar as referências de solo, em cada escala fotográfica estudada, conforme sua textura topográfica. Os resulta. dos obtidos estão no quadro 13.

As classes de textura topogrăfica serviram também como fator de distinção entre os solos podzólicos e os latossolos.

Com a variação da escala fotográfica utilizada, este indịce só evidenciou diferença entre a escala 1:25.000 e as outras duas, na classificação dos resultados para a referência $S_{1}$, tendo sido idêntica nas três escalas para todas as outras referências de solo.

Discordando em parte de DEMETRIO (1977), os solos podzólicos agora estudados foram classificados como de textura topográfica média, com excessão dos da referência $S_{1}$ na escala $E_{3}$. Para os latossolos, a classificação foi concordante com aquelas obtidas por outros autores como SOUZA (1975) e DEMÉTRIO (1977).

4.5. Características descritivas do padrão de drenagem

O quadro 14 transcreve as características descritivas dos padrões de drenagem das referências de solo, analisadas em todas as amostras obtidas com as fotografias nas três escalas.

Nota-se a possibilidade de distinção entre os solos podzólicos e os latossolos, porém a tendência de aproximação das características quantitativas das referências $\mathrm{S}_{3}$ e $\mathrm{S}_{4}$ e as pequenas diferenciações destas com as da referência $S_{5}$ não são perceptíveis por esta análise.

Conforme observaram KOFFLER (1976a) e DEMETRIO (1977), não hã necessidade de análise destas características, pelas informações obtidas através de material fotográfico em 
58.

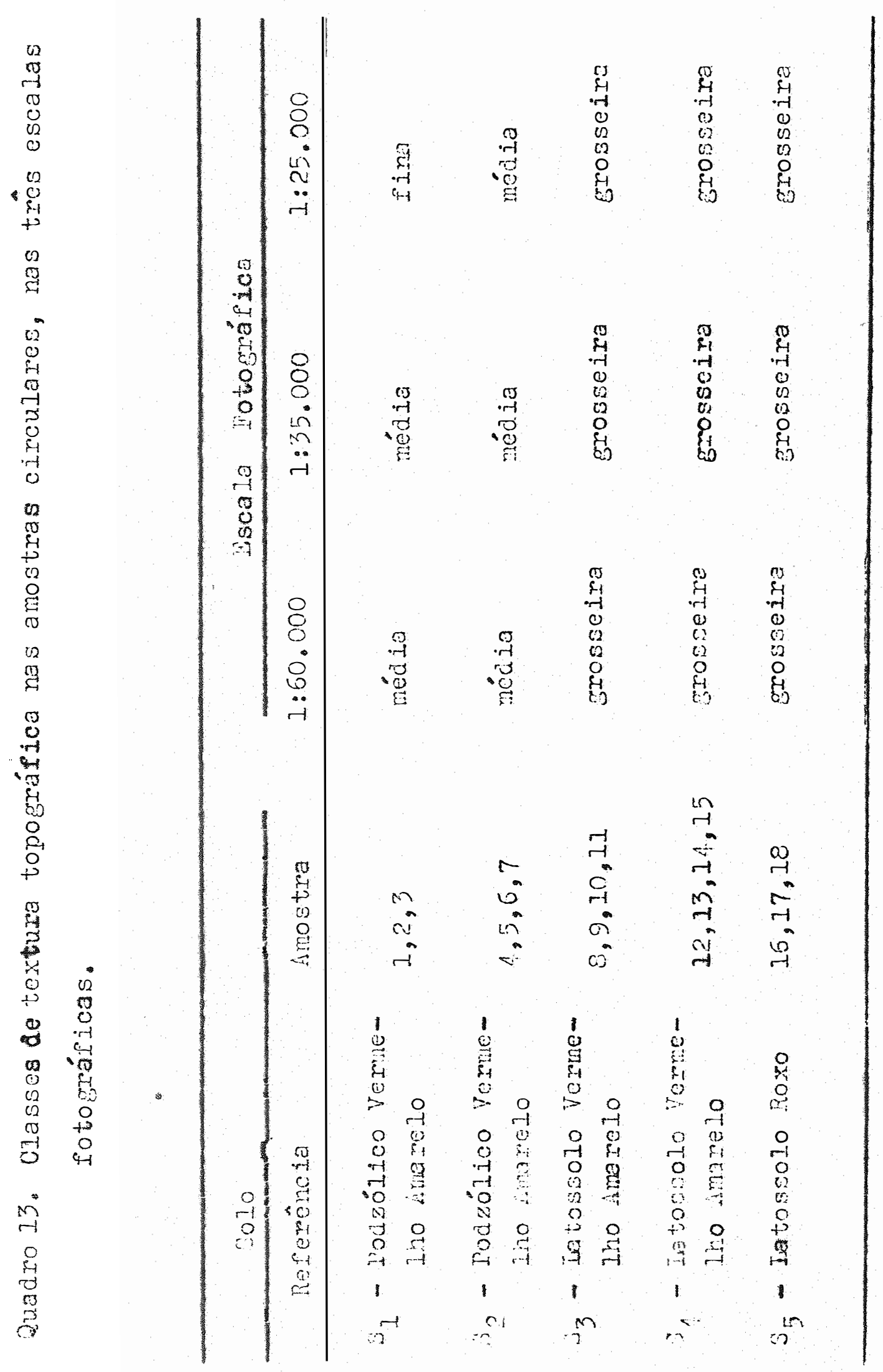


60.

cada escala, separadamente. Conforme diversos autores, como os que trabalharam em nossas condições desde FRANÇA (1968), a descrição do tipo ou modelo do padrão de drenagem segundo PARVIS (1950) é complementada pelas outras características propostas por LUEDER (1959). Tambëm pareceu conveniente a descrição de anomalias que porventura ocorram, para melhor caracterizar o padrão, conforme proposta de RICCI e PETRI (1965) devido às observações de MILLER e MILLER (1961).

\subsection{Sugestões para novas pesguisas}

Tendo em vista a experiência adquirida no desenvolvimento deste trabalho, sugerem-se estudos sobre a influência do tamanho de amostras circulares para a anālise de cada indice de drenagem em função da natureza dos solos. 
5. CONCLUSÕES

Analisando-se características de rede de drenagem superficial de cinco referências de solo através de fotografias em três escalas, chegou-se ãs conclusões apresentadas a seguir.

O emprego de amostras circulares para obtenção de parâmetros da rede de drenagem é adequado para estudos cie Eotopedologia.

Embora os parâmetros descritivos do padrão de drenagem sejam adequados, não são suficientes para evidenciar diferenças entre unidades de solo, sendo mais recomendāvel a utilização de parâmetros quantitativos, entre os quais destaca-se a densidade de drenagem como o mais eficiente.

A utilização conjunta dos indices frequência de rios e razão de textura, para a caracterização de padrões de drenagem em amostras circulares, não é necessária porque eles guardam entre si uma relação numérica constante, deperdente dos valores do perímetro e da área do círculo. Recomenda-se o emprego da razão de textura porque, através de seus valores médios, permite classificar o relevo da área amostral segundo sua textura topográfica.

Não há interesse na inclusão do comprimento médio dos canais entre os parâmetros caracterizadores do "pa- 
drão de drenagem, porque ele expressa relação numērica entre outros indices mais eficientes.

Em virtude de não se ter constatado efeito significativo da variação de escala, recomenda-se a utilização de material fotográfico de menor escala, desde que se disponha de alternativa.

o emprego de material fotográfico de escala pequena apresenta vantagens de implicar em manuseio de meno: quantidade de fotografias, simplificando o trabalho de escritório, e de permitir melhor percepção do relevo. 
63.

6. LITERATURA CITADA

AMARAL, A.Z. e R. AUDI, 1972. Fotopedologia. In: MONIZ, A.C., coord. Elementos de Pedologia. São Paulo, Polígono, Ed. Universidade de São Paulo. p. 429-442.

AUDI, R., 1972. Fotointerpretação de atributos dos canais de drenagem em solos da região noroeste do Estado de são Paulo. Piracicaba, ESALQ/USP. 182p. (Tese de Doutoramen to) .

BRASIL. Instituto Brasileiro de Geografia, 1969. Carta do Brasil - Escala 1:50.000. Folha topográfica de Araras.

BRASIL. Instituto Brasileiro de Geografia, 1971a. Carta do Brasil - Escala 1:50.000. Folha topográfica de Leme.

BRASIL. Instituto Brasileiro de Geografia, 1971b. Carta do Brasil - Escala 1:50.000. Folha Topográfica do Rio Cape tinga.

BRASIL. Instituto Brasileiro de Geografia .1972. Carta do Brasil - Escala 1:50.000. Folha topográfica de Aguaí.

BRASIL. Instituto Brasileiro de Geografia, 1974a. Carta do Brasil - Escala 1:50.000. Folha topográfica de Campinas. 
BRASIL. Instituto Brasileiro de Geografia, 1974b. Carta do Brasil - Escala 1:50.000. Folha topográfica de Conchal.

BOMBERGER, E.H. e H.W. DILL, 1960. Photo interpretation in agriculture. In: Manual of Photographic Interpretation. Washington, American Society of Photogrammetry. p. 561 632 .

BURINGH, P., 1960. The applications of aerial photographs in soil surveys. In: Manual of Photographic interpretation. Washington, American Society of Photogrammetry. p. 633 666.

CAMPOS, H. 1976. Estatistica Experimental Não Paramétrica. Piracicaba, Departamento de Matemática e Estatística, ESALQ/USP . p. 190-213.

CARVALHO, W.A., 1977. Fotointerpretação de bacias hidrográficas em amostras circulares de redes de drenagem de solos com horizonte B textural. Piracicaba, ESALQ/USP. $126 \mathrm{p}$. (Tese de Doutoramento).

CRESWICK, W.A. e W.H. ROCKWELL, 1959. Applications of aerial-photographic techniques to agricultural surveys. In: LUEDER, D.R. Aerial Photographic Interpretation - Principles and applications. New York, McGraw-Hill Book Co. p. $373-385$.

DEMETRIO, V.A., 1977. Variação de características de redes de drenagem em função da escala das fotografias aéreas verticais. Piracicaba, ESALQ/USP. 107 p. (Dissertação de Mestrado).

FADEL, H., 1972. Fotointerpretação de bacias e de redes de drenagem de três solos da Fazenda Ipanema, Município de Araçoiaba da Serra (SP) . Piracicaba, ESALQ/USP. 92 p. (Dissertação de Mestrado). 
FRANÇA, G.V., 1968. Interpretação fotogräfica de bacias e rę des de drenagem aplicada a solos da região de Piracicaba. Piracicaba, ESALQ/USP. 151 p..(Tese de Doutoramento):

FREIRE, J.C., 1977. Fotointerpretação de redes de drenagem de três solos da região de Alpinópolis, Minas Gerais. Piracicaba, ESALQ/USP. 136 p. (Tese de Doutoramento).

FROST, R.E., 1960. Photointerpretation of soils. In: Manual of Photographic Interpretation. Washington, American Society of Photogrammetry. p. 343-402.

GoOSEN, D., 1960. Interpretacion de Fotos Aereas y su Importancia en Levantamiento de Suezos. Roma, Organización de las Naciones Unidas para la Agricultura y la Alimentación (Boletin sobre suelós no 6) $58 \mathrm{p}$.

HORTON, R.E., 1945. Erosional development of streams and their dreinage basins: hydrophysical approach to quantitative morphology. Bul. Geol. Soc. Amer. 56: 275-370.

KOFFLER, N.F., 1976a. Utilização de imagens aerofotogräficas e orbitais no estudo do padrão de drenagem em solos originados do arenito Bauru. São José dos Campos (SP), INPE. $167 \mathrm{p}$. (Dissertação de Mestrado).

KOFFLER, N.F., 1976b. Anälise aerofotogräfica da influência da área de amostragem circular na caracterizaça quantitativa do padrão de drenagem. São Josē dos Campos (SP), INPE. $20 \mathrm{p}$.

LEÃO, S.R.F., 1973. Interpretação fotogräfica dos padrões de drenagem desenvolvidos em dois solos do Distrito Federal. Piracicaba, ESALQ/USP. 110 p. (Dissertação de Mestrado).

LUEDER, D.R., 1959. Aerial Photographic Interpretation Principles and Applications. New York, McGraw-Hill Book Co. $462 \mathrm{p}$. 
MARCHETTI, D.A.B., 1969. Fotointerpretação de atributos de relevo aplicada a solos da região de Piracicaba. Piraci caba, ESALQ/USP. 58 p. (Tese de Doutoramento).

MILLER, V.C. e C.F.MILLER, 1961. Photogeology. New York, MCGraw-Hill Co. 248 p.

OLIVEIRA, J.B.; J.R.F. MENK e C.L. ROTTA, 1979. Levantamento pedológico semi-detalhado do Estado de são Paulo - Qua drícula de Campinas. Rio de Janeiro, Instituto Brasileiro de Geografia. (no prelo).

PARVIS, M. 1950. Drainage pattern significance in airphoto identification of soils and bedrocks. Photogram. Eng. 16 (3): $387-408$.

RABBEN, E.L., 1960. Fundamentals of photointerpretation. In. Manual of Photographic Interpretation. Washington, American Society of Photogrammetry. p. 99-186.

RAY, R.G., 1963. Fotografias Aëreas na Interpretacão e Mapeamento Geológico. (Tradução de Jesuíno Felicíssimo Jr.) São Paulo, Instituto Geográfico e Geológico. 163 p.

RAY, R.G. e W.A. FISCHER, 1960. Quantitative photography: a geological research tool. Photogram. Eng. 26(1) : 143 150 .

RICCI, M. e S. PETRI, 1965. Principios de Aerofotogrametria e Interpretąão Geológica. São Paulo, Ed. Nacional. p. 102110 .

ROURKE, J.D. e M.E. AUSTIN, 1951. The use of air-photos for soil classification and mapping in the field. Photogram. Eng. $16(5): 738-747$.

SÃO PAULO. Instituto Geogräfico e Geológico, 1964. Geologia do Estado de São Paulo. (Boletim no 41). 263 p. 
SÃO PAULO. Instituto Geográfico e Geológico, 1974. Mapa Geo Zógico do Estado de São Paulo. (Escala 1:1.000.000).

SÃO PAULO. Departamento de Águas e Energia Elétrica, 1975. Boletim Fluviométrico No 3. $175 \mathrm{p}$.

SetZer, J., 1966. Atlas Climático e Ecológico do Estado de São Paulo. São Paulo, Comissão Interestadual da Bacia Paranā - Uruguai. $61 \mathrm{p}$.

SILVA, L.C.F., 1977. Fotointerpretação de redes de drenagem de dois solos do município de são Pedro (SP). Piracicaba, ESALQ/USP. 114 p. (Dissertação de Mestrado).

SMITH, K.G., 1950. Standards for grading texture of erosional topography. Amer. J. Sci. 248: 655-668.

SMITH, G.D. e A.R. AANDAHL, 1957. Soil classification and surveys. In: Soil. Washington, USDA, (Year Book of Agri culture) p. 396-400.

SOUZÀ, M.L.P., 1975. Fotointerpretação das redes de drenagem de três solos com horizonte B latossólico ocorrentes no municipio de Ponta Grossa - PR. Piracicaba, ESALQ/USP . 135 p. (Dissertação de Mestrado).

STRAHLER, A.N., 1952. Hypsometric (area-altitude) analysis of watershed geomorphology. Trans. Amer. Geophys. Union. 38: 913-920.

VASQUES FILHO, J., 1972. Critérios morfométricos aplicados à fotointerpretação de redes de drenagem de três unidades de solos do município de Piracicaba (SP). Piracicaba, ESALQ/USP. 113 p. (Tese de Doutoramento) .

VERA, L., 1964. Técnicas de Inventärio de la Tierra Agricola: EI Proyecto Aerofotogramétrico OEA/Chile. Washington, Unión Panamericana. (Manuales Técnicos X) $136 \mathrm{p}$. 
68.

VON ENGELN, O.D., 1942. Geomorphology: Systematical and Re gional. New York, The McMillan Co. $655 \mathrm{p}$. 
69.

APENDICE 


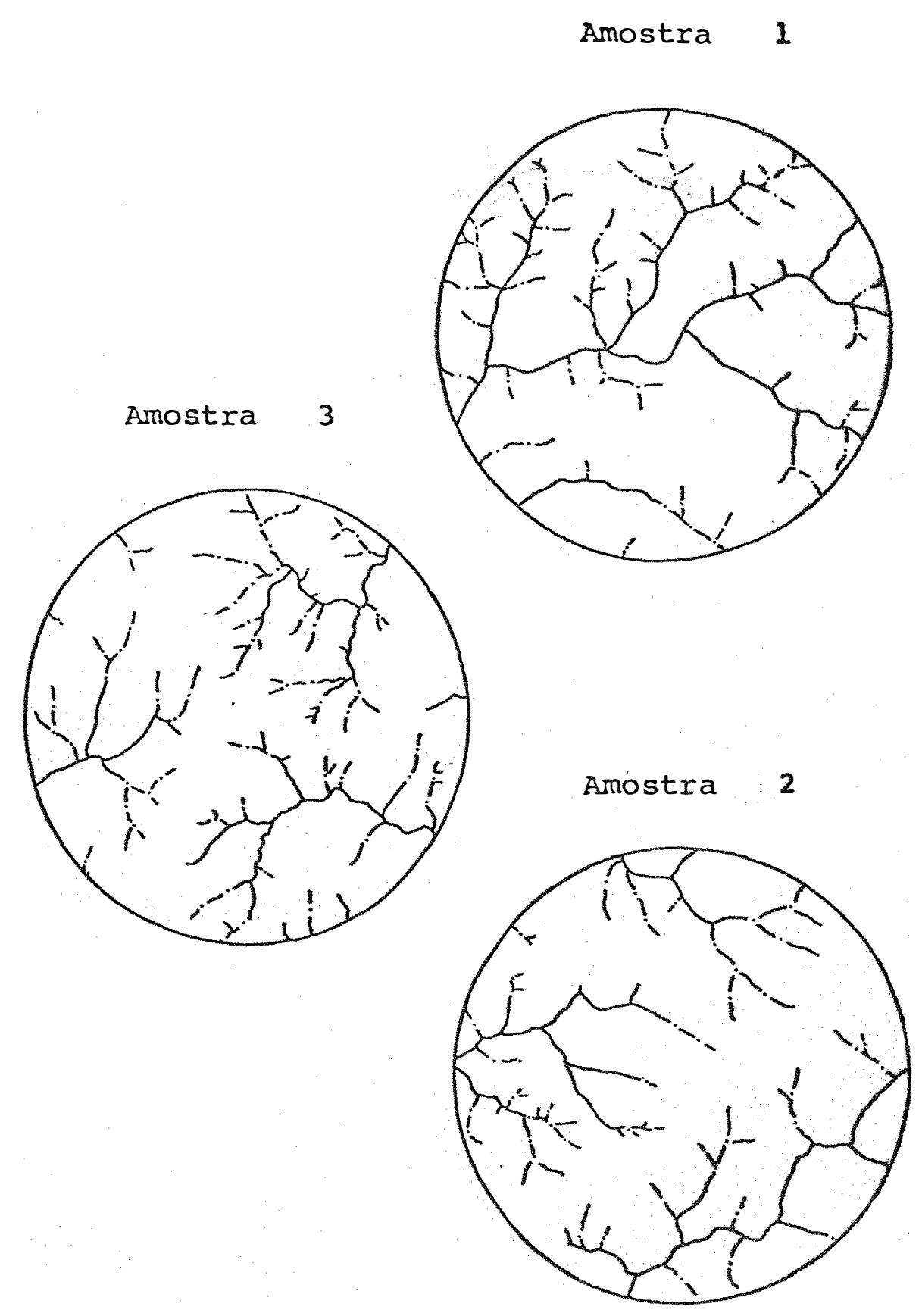

Figura 1. Amostras circulares 1, 2 e 3, representativas da unidade de solo Podzólico Vermelho Amarelo, na escala aproximada 1: 60.000 . 
Amostra 4

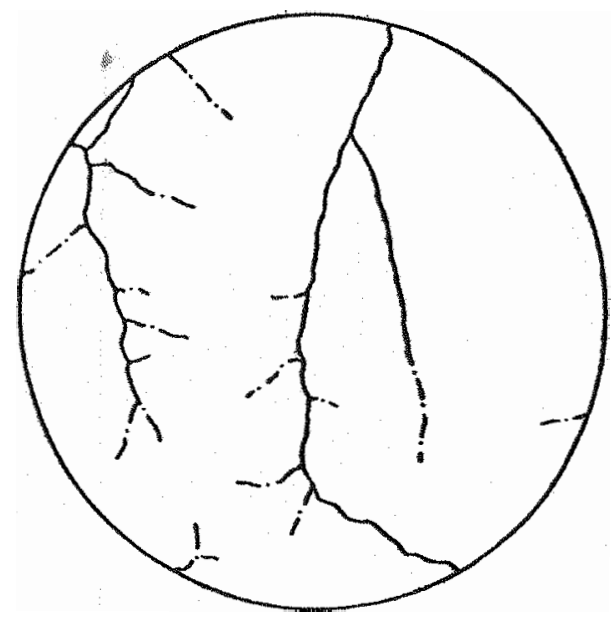

Amostra 6

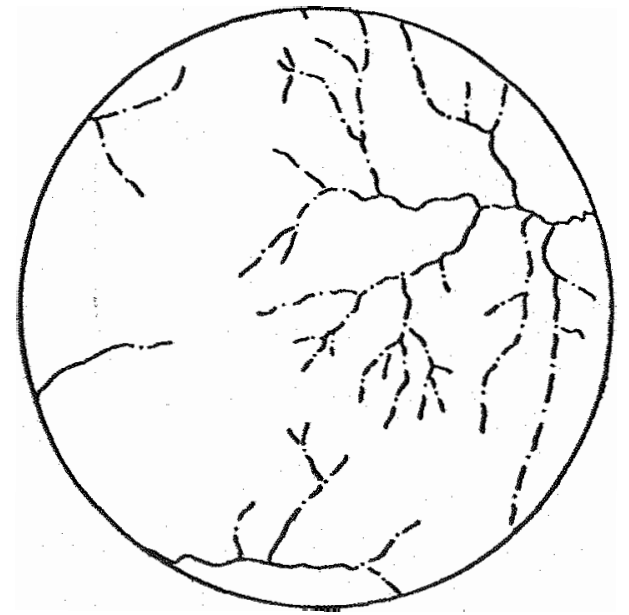

Amostra 5

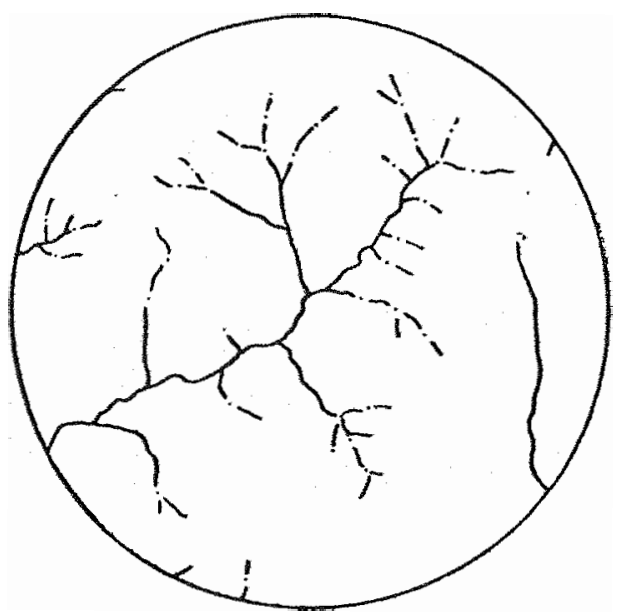

Amostra 7

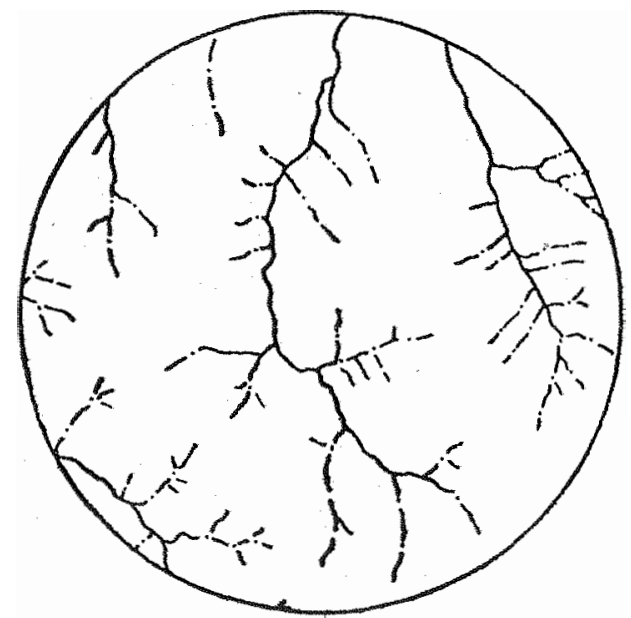

Figura 2. Amostras circulares 4, 5, 6 e 7, representati vas da unidade de solo Podzólico Vermelho Ama relo, na escala aproximada $1: 60.000$. 

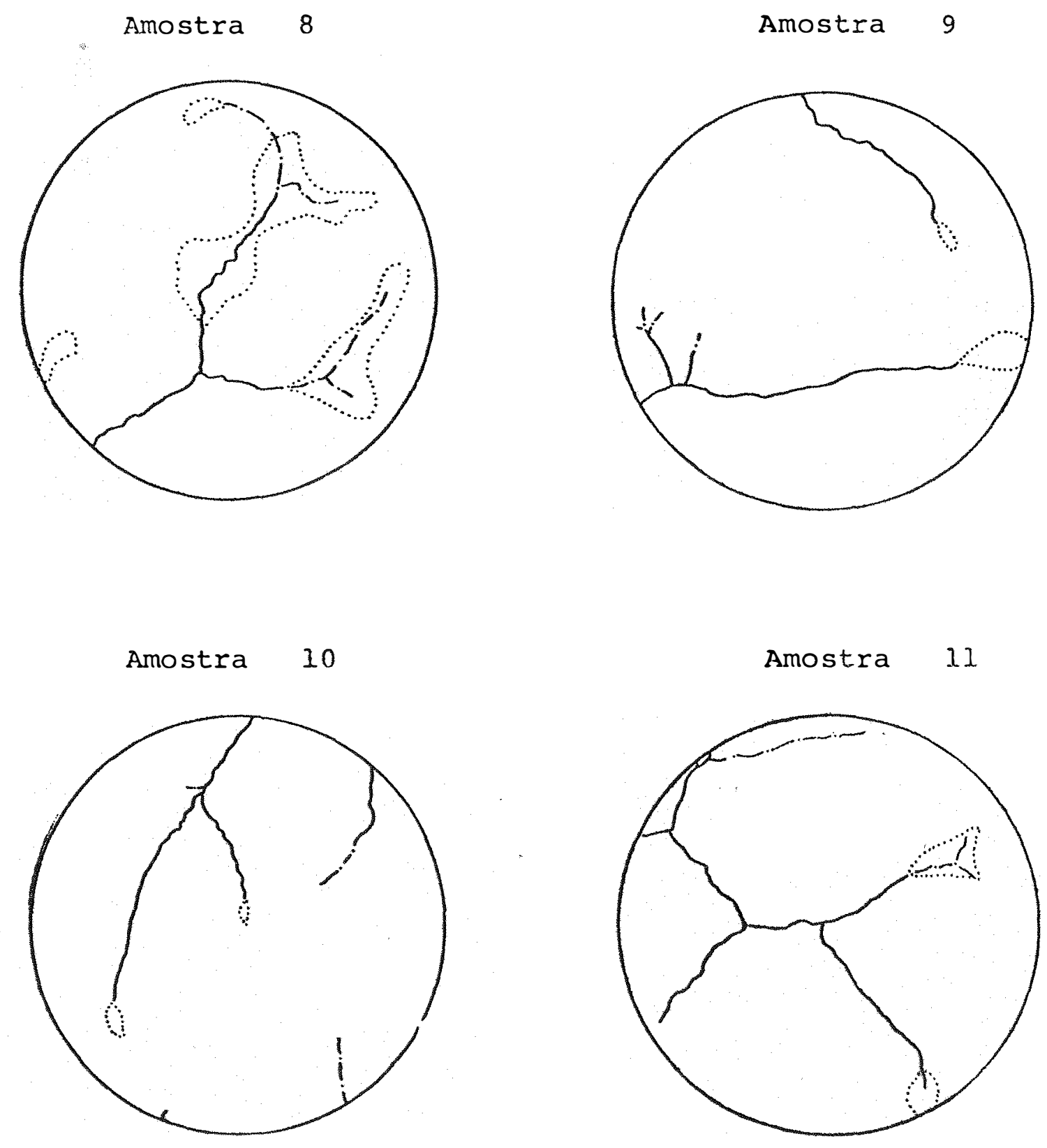

Figura 3. Amostras circulares $8,9,10$ e 11, representati vas da unidade de solo Latossolo Vermelho Amare 10, na escala aproximada 1:60.000. 
73.

Amostra 12

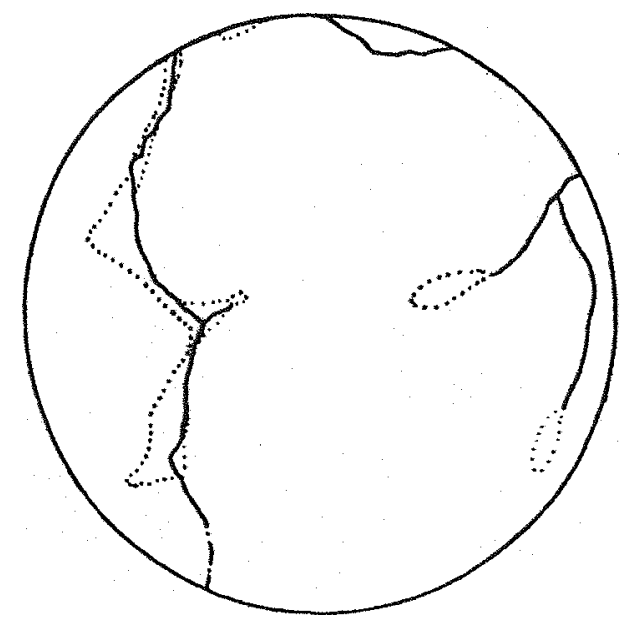

Amostra 14

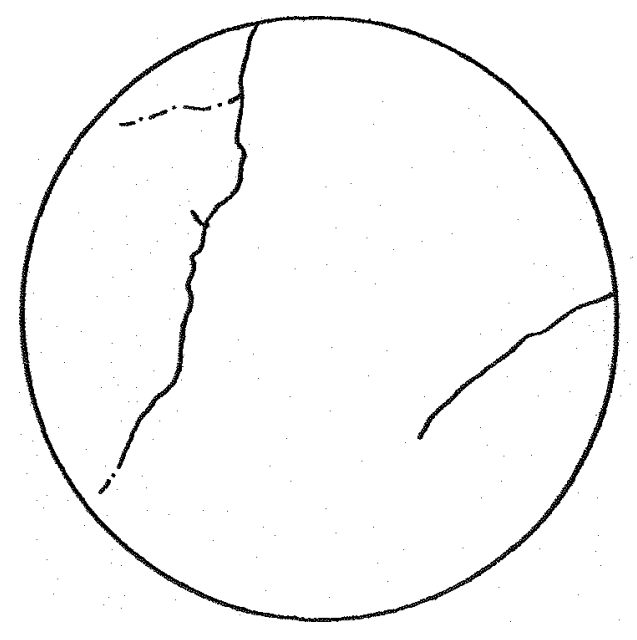

Amostra 13

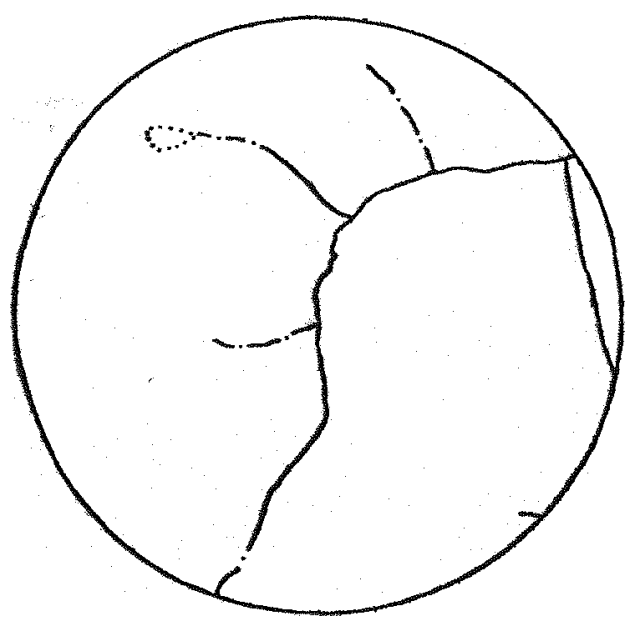

Amostra 15

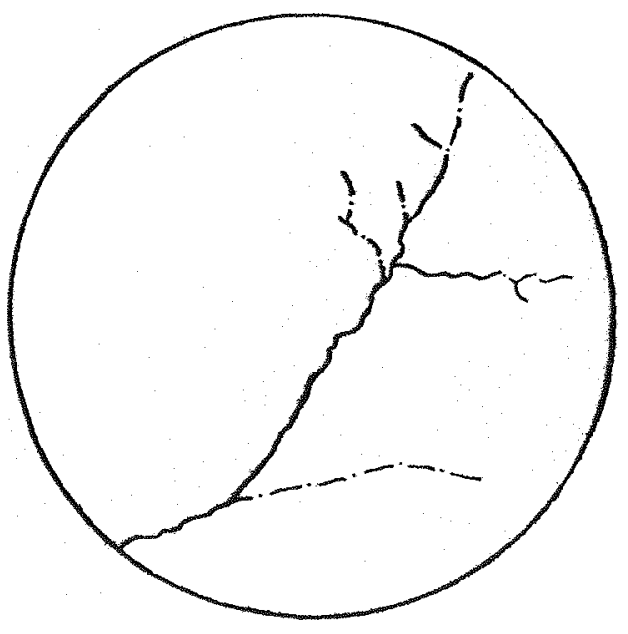

Figura 4. Amostras circulares 12, 13, 14 e 15, representa tivas da unidade de solo Latossolo Vermelho Ama relo, na escala aproximada 1: 60.000 . 
Amostra 16

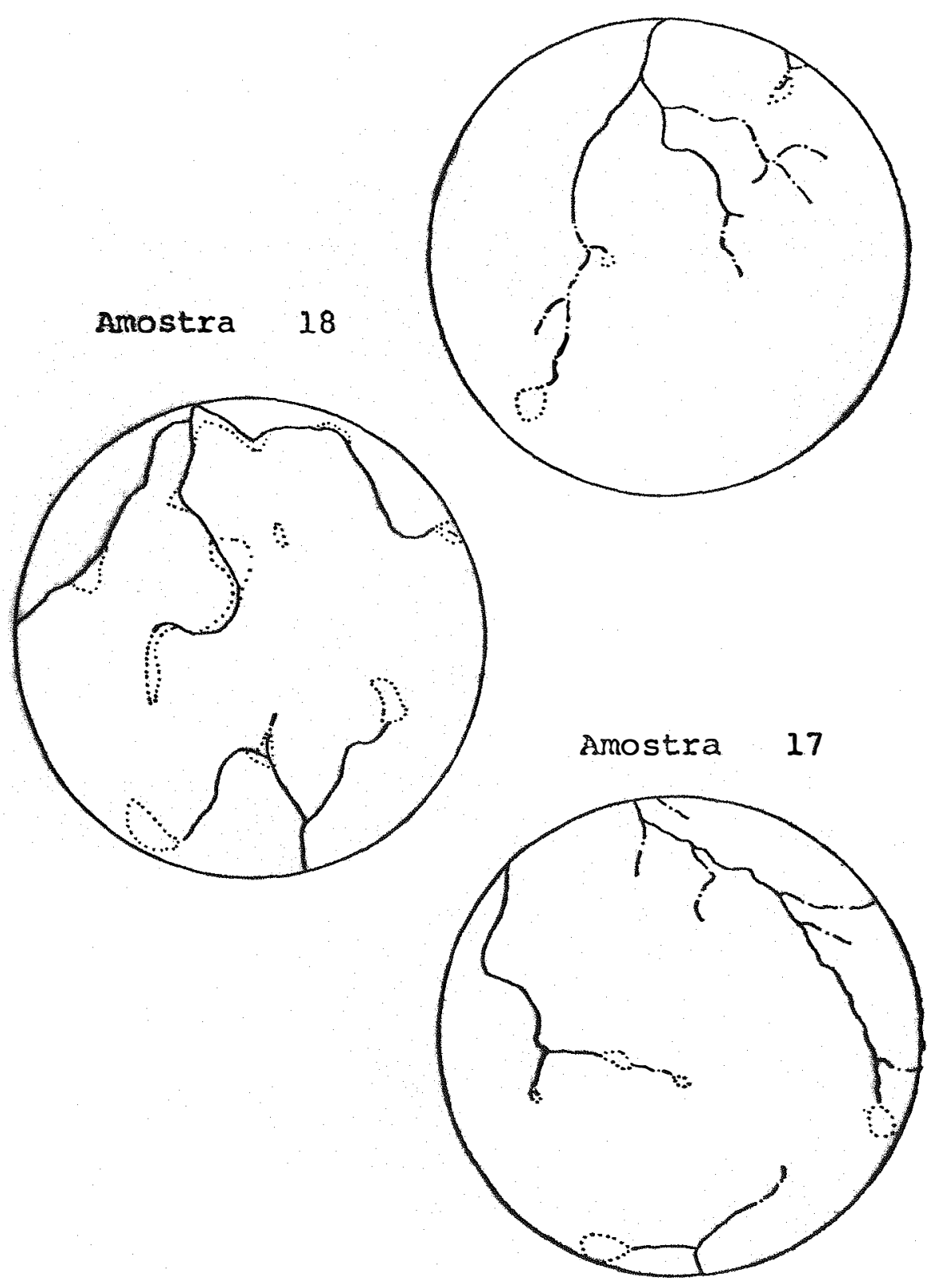

Figura 5. Amostras circulares 16, 17el8, representativas da untdade de solo Latossolo Roxo, na escala aproximada 1: 60.000 . 
75.

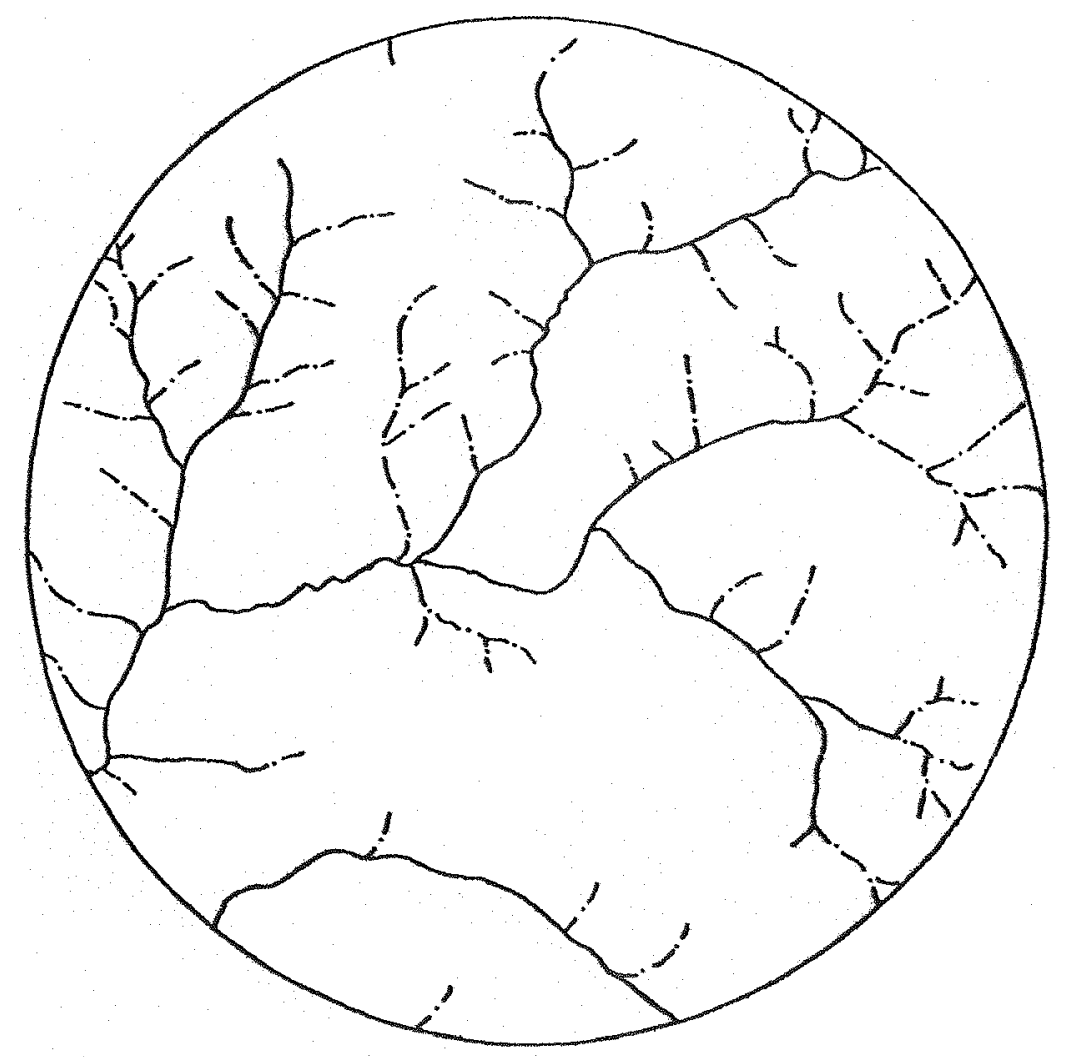

Figura 6. Amostra circular l, representativa da unidade de solo podzólico vermelho Amarelo, na escala aproximada 1: 35.000 . 


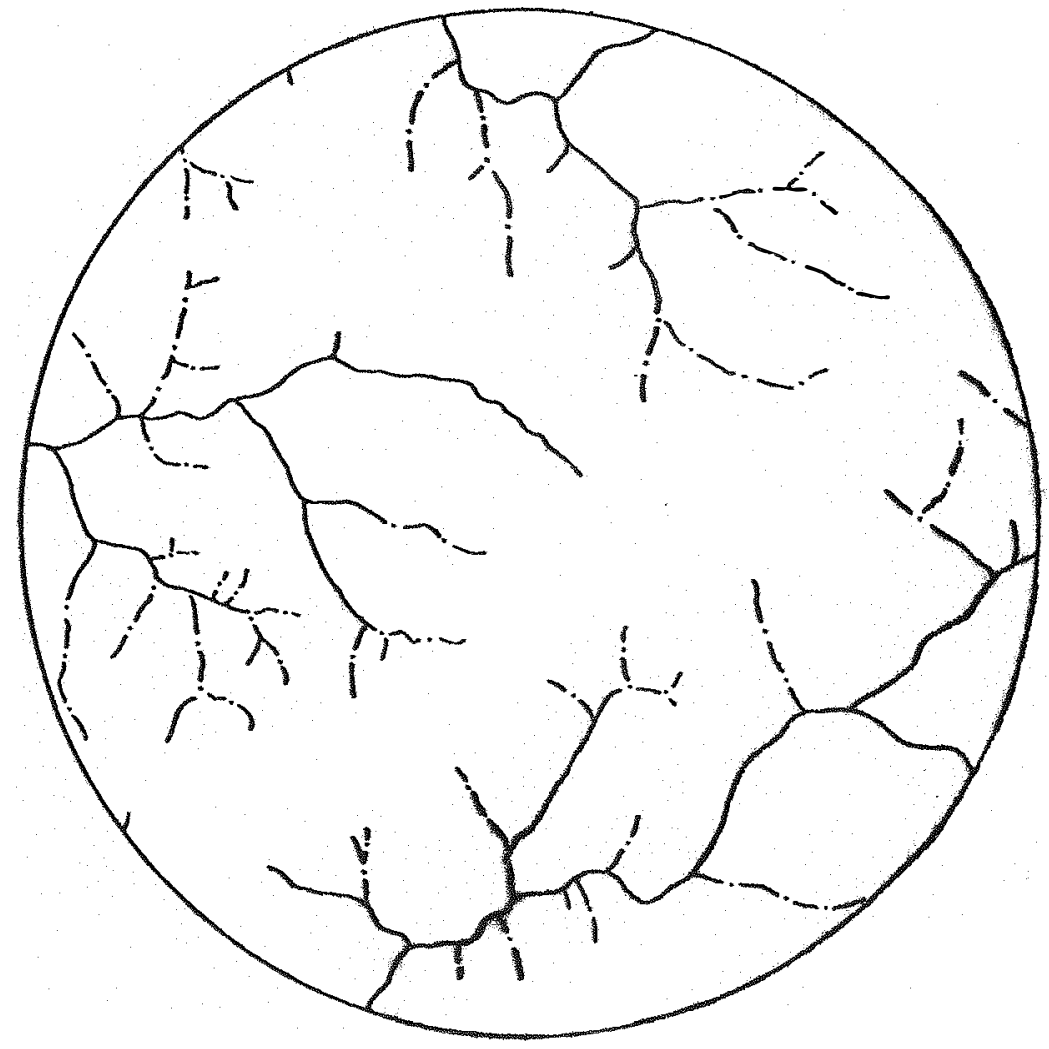

Figura 7. Amostra circular 2, representativa da unidade de solo Podzólico Vermelho Amarelo, na escala aproximada $I: 35.000$. 
77.

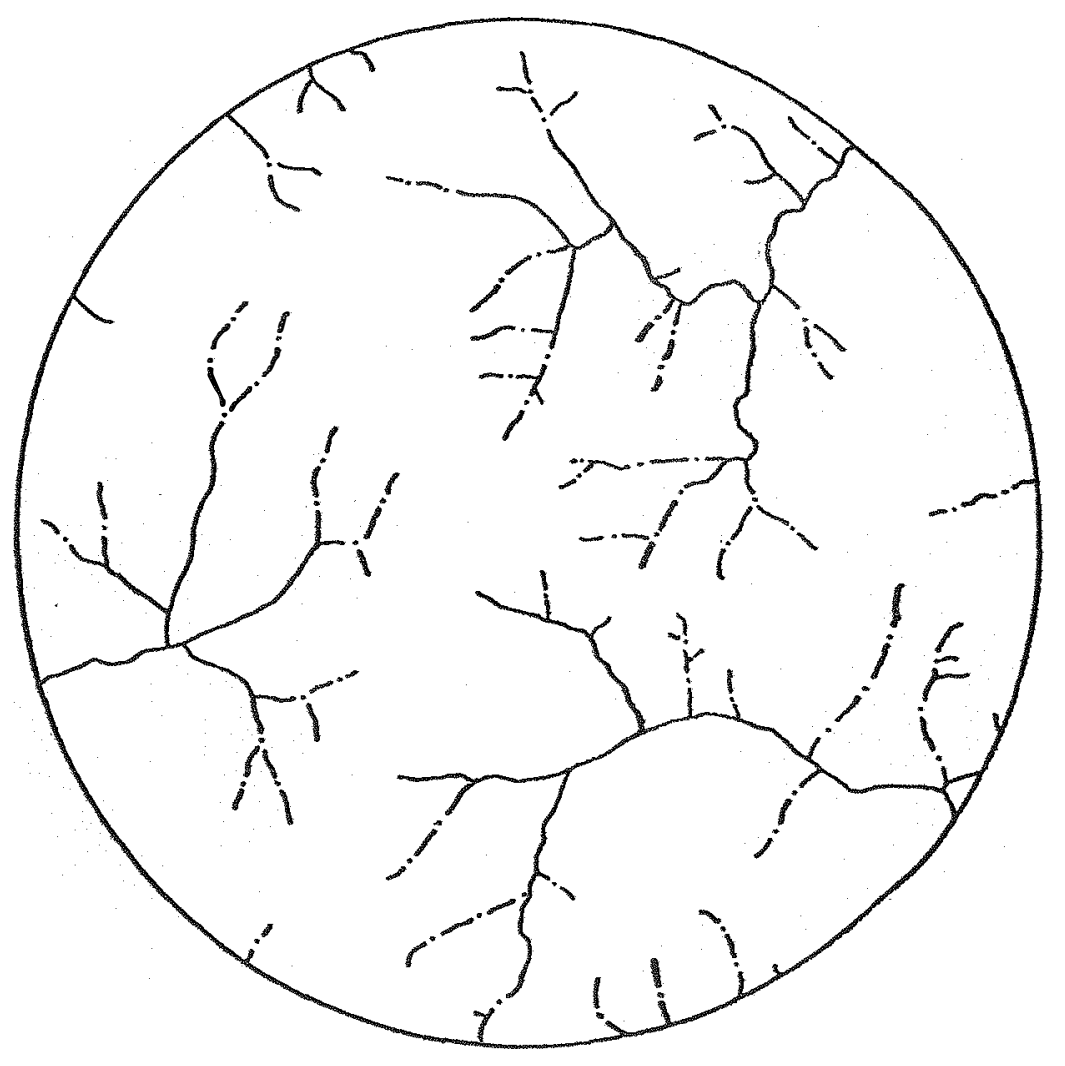

Figura 8. Amostra circular 3, representativa da unidade de solo Podzólico Vermelho Amarelo, na escala aproximada $1: 35.000$. 
78.

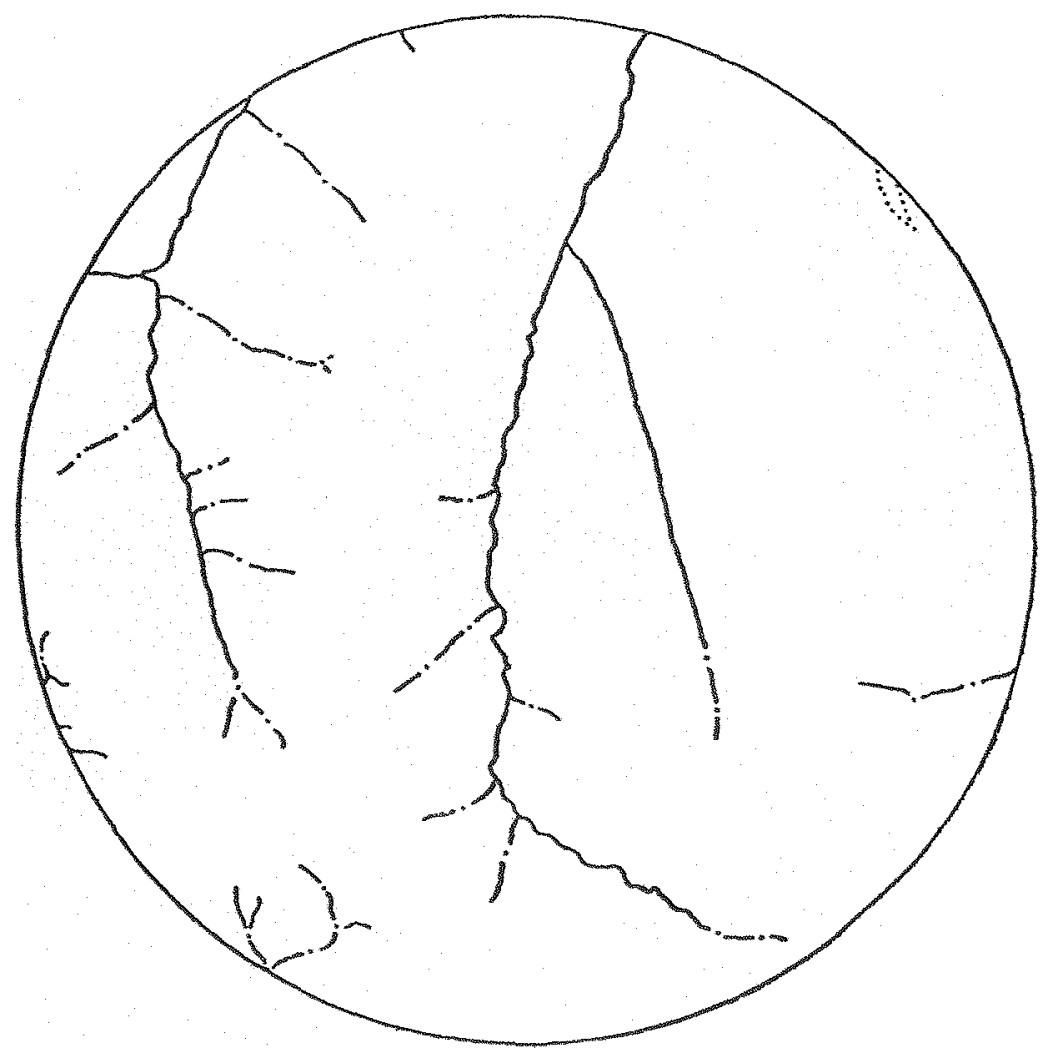

Figura 9. Amostra circular 4, representativa da unidade de solo Podzólico Vermelho Amarelo, na escala aproximada $1: 35.000$. 
79.

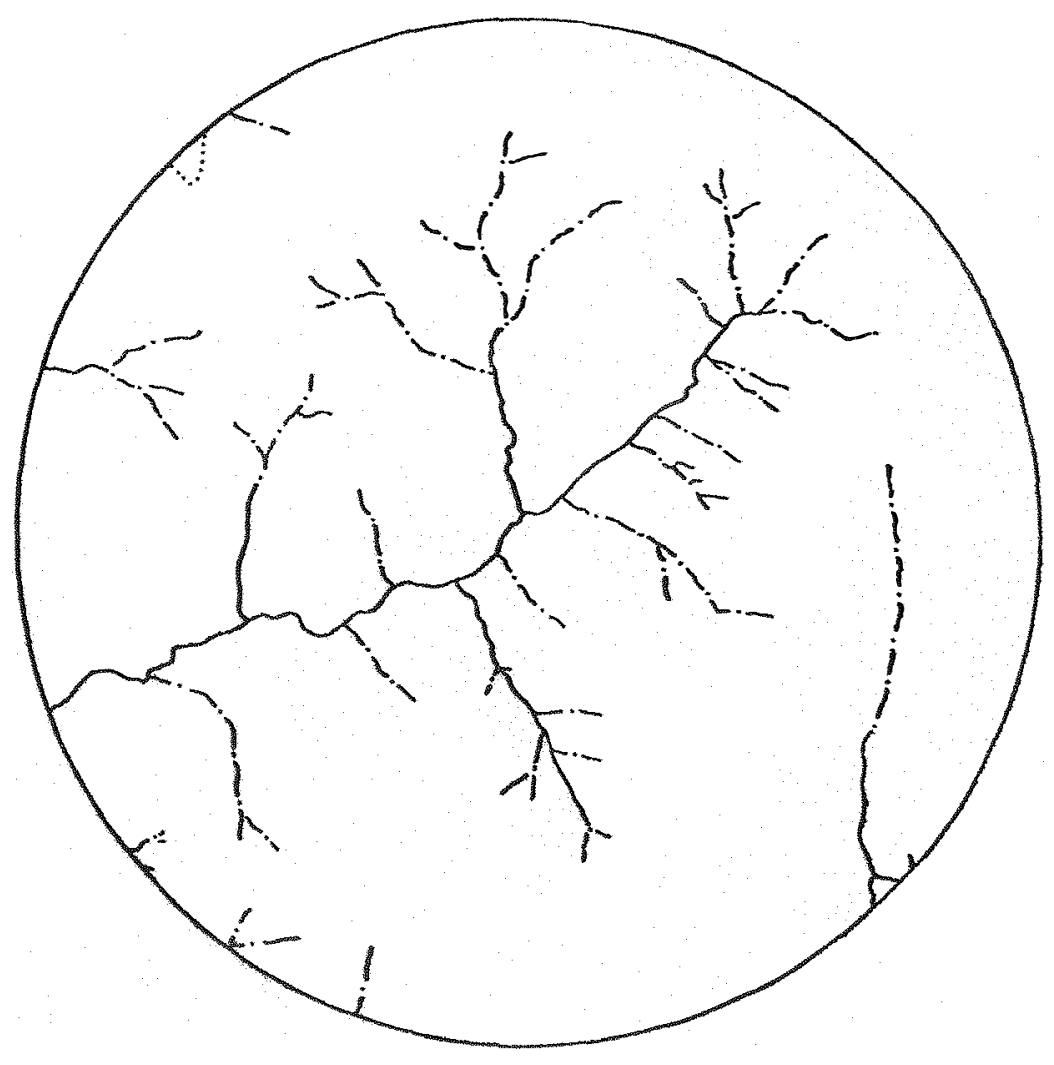

Figura 10. Amostra circular 5, representativa da unidade de solo Podzólico Vermelho Amarelo, na escala aproximada 1: 35.000 . 
80.

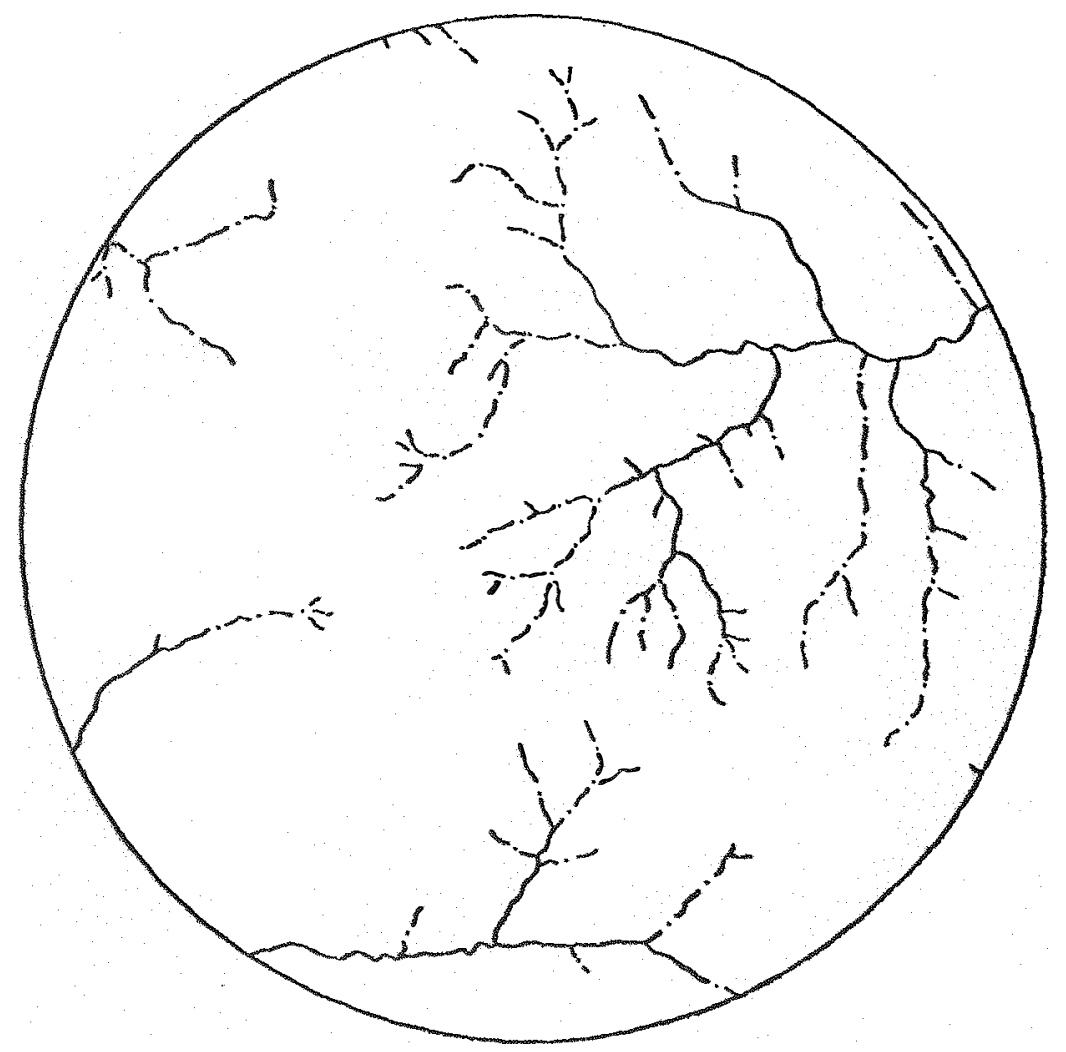

Figura 11. Amostra circular 6, representativa da unidade de solo Podzólico Vermelho Amarelo, na escala aproximada $1: 35.000$. 
81.

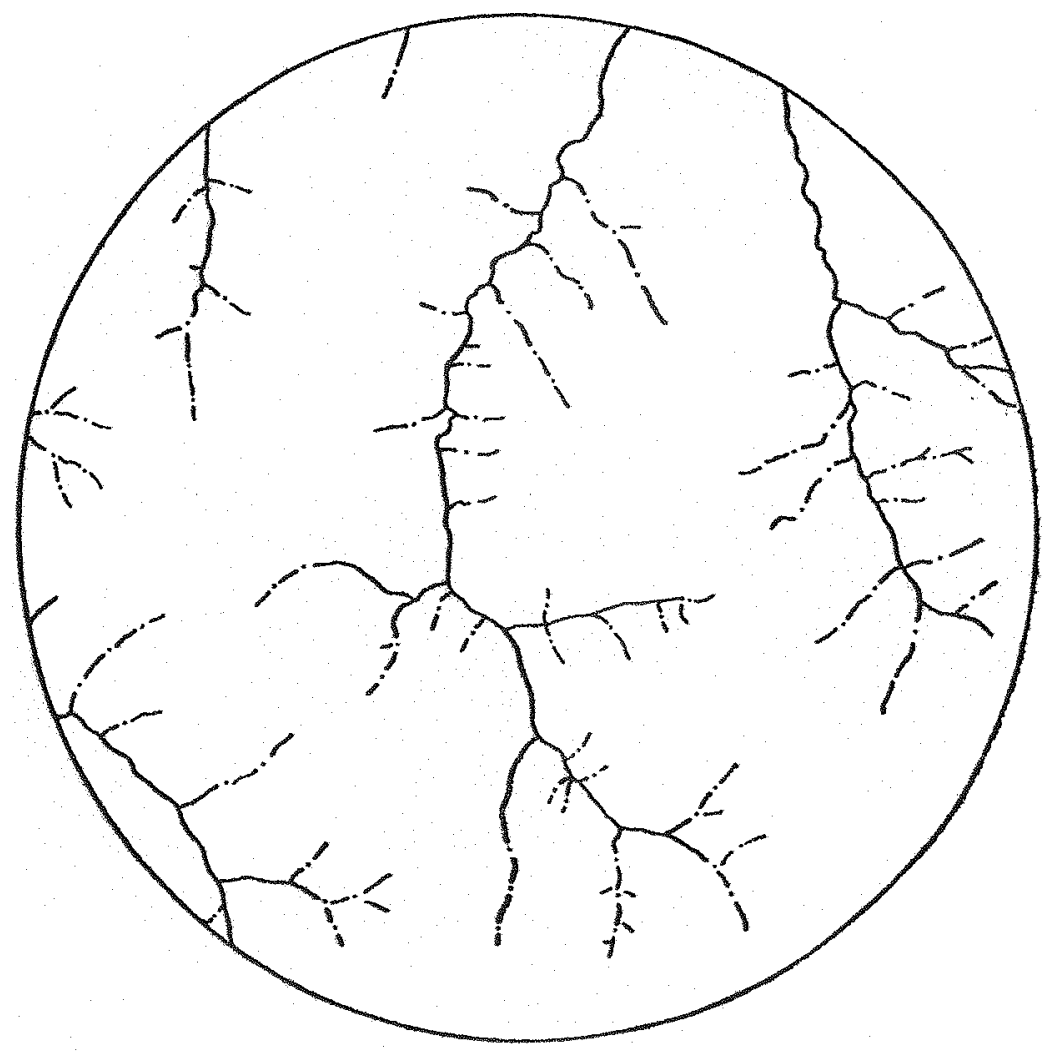

Figura 12. Amostra circular 7, representativa da unidade de solo Podzólico Vermelho Amarelo, na escala aproximada $1: 35.000$. 
82.

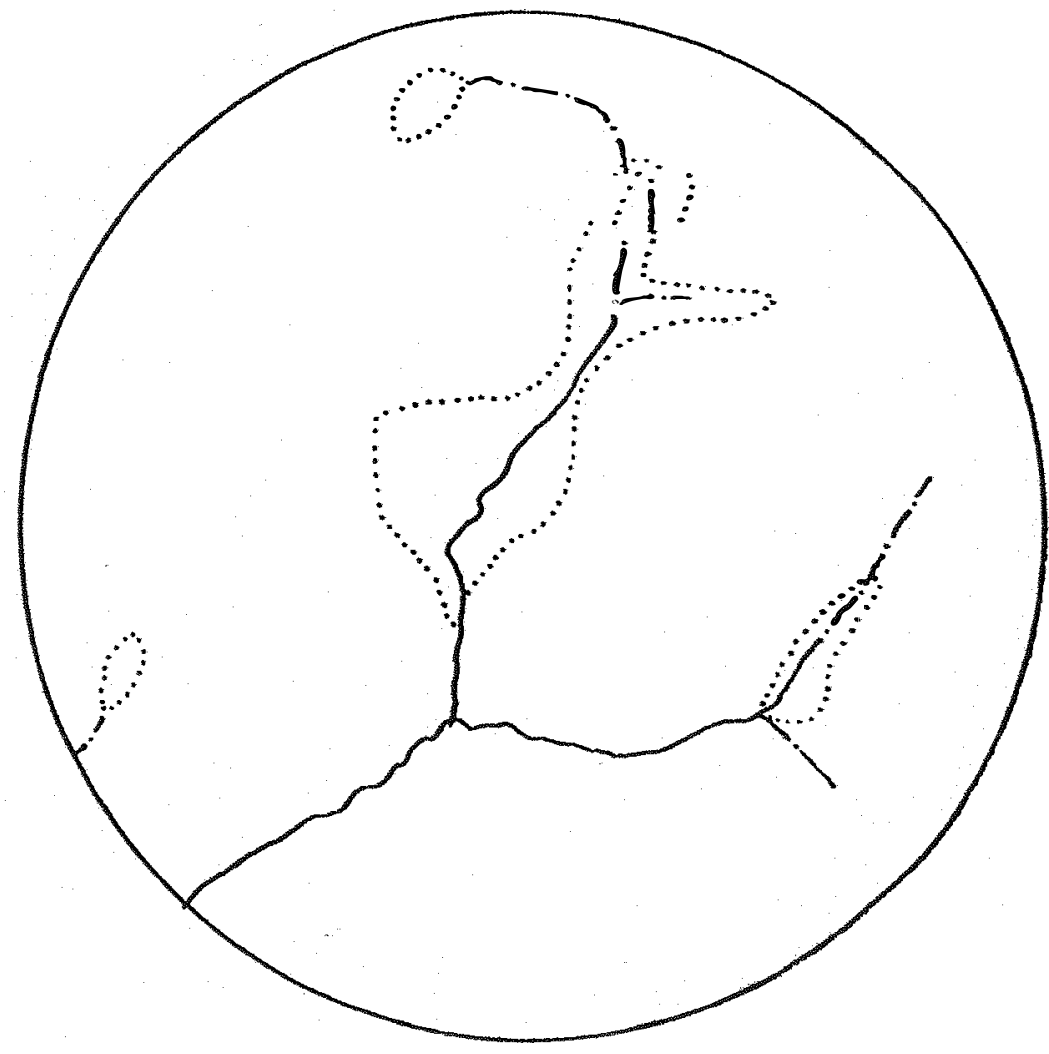

Figura 13. Amostra circular 8, representativa da unidade de solo Latossolo Vermelho Amarelo, na escala aproximada 1: 35.000 . 


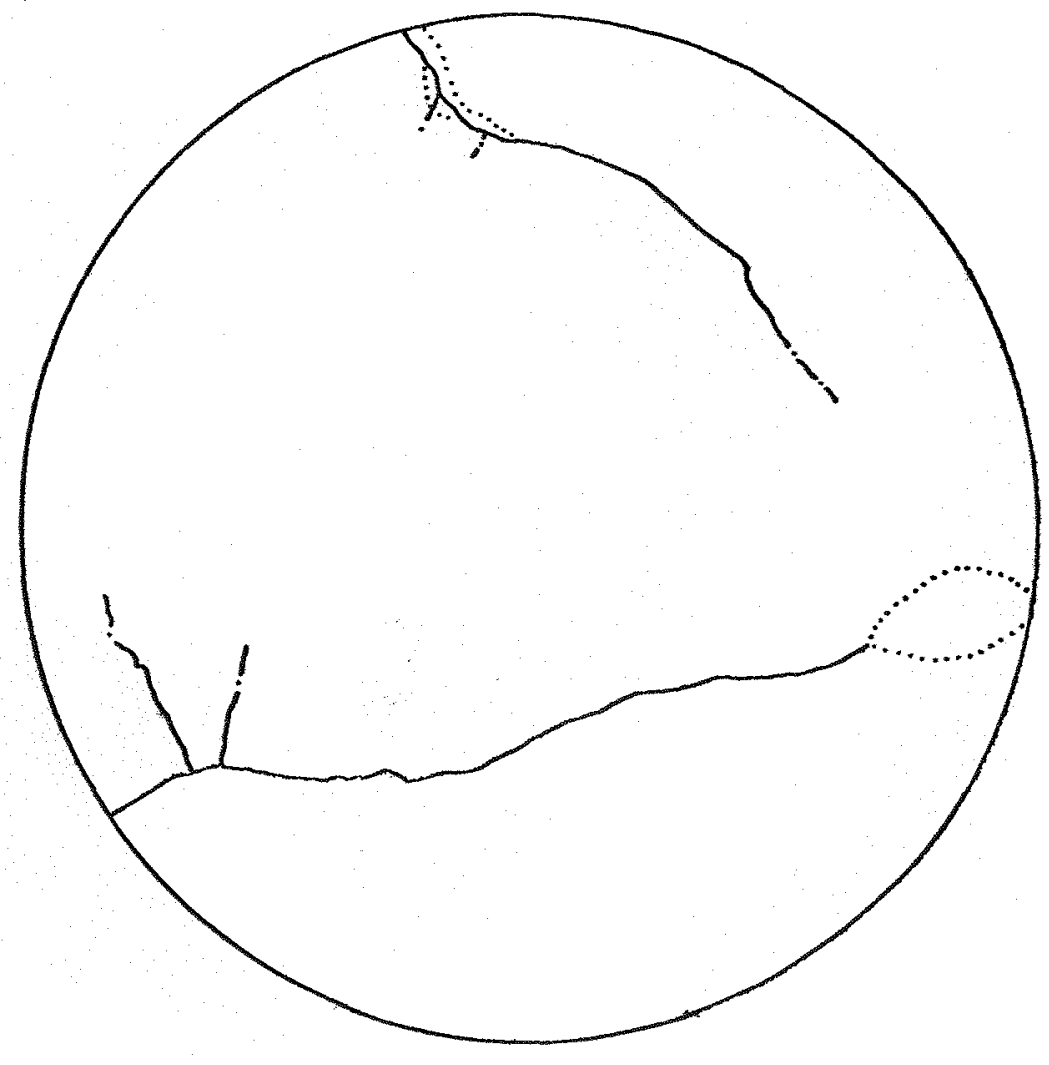

Figura 14. Amostra circular 9, representativa da unidade de solo Latossolo Vermelho Amarelo, na escala aproximada 1: 35.000 . 
84.

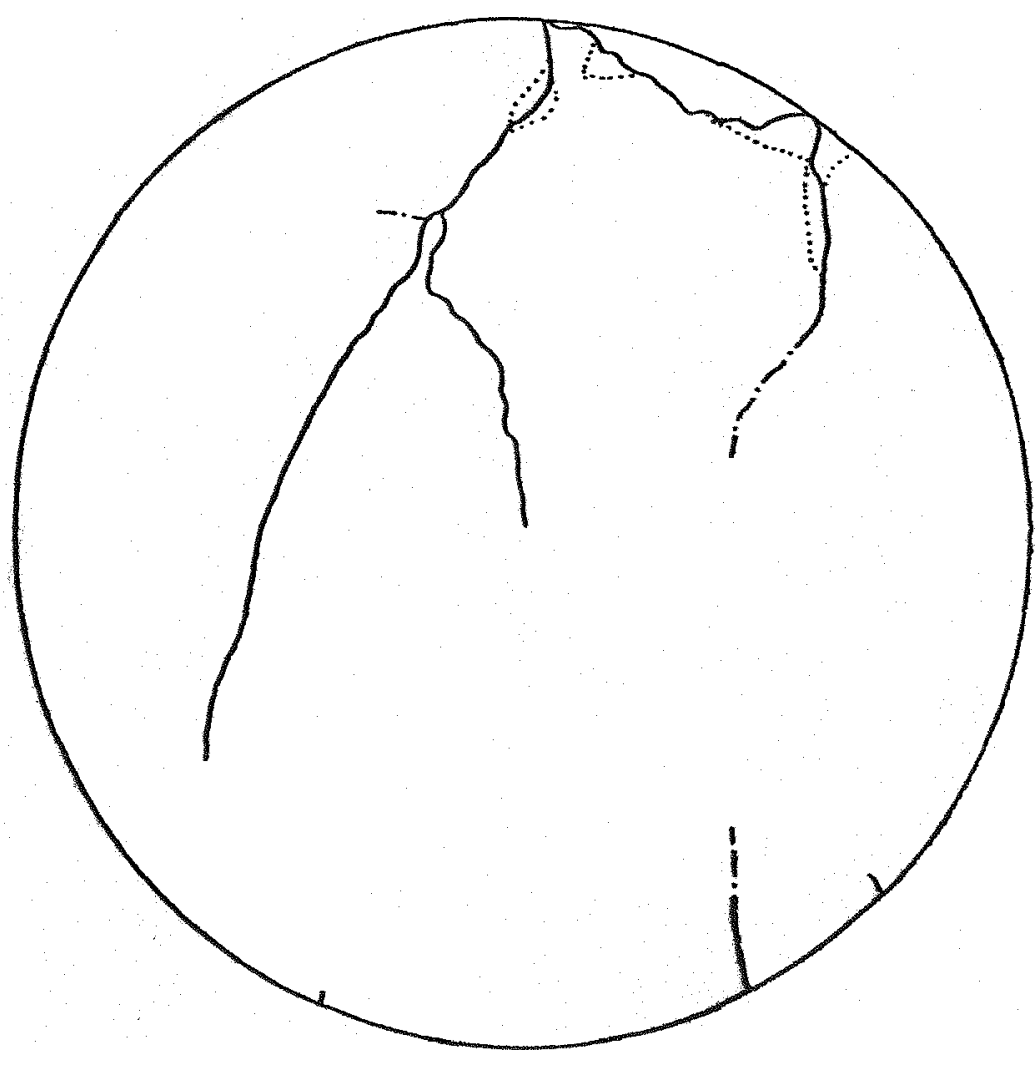

Figura 15. Amostra circular 10, representativa da unidade de solo Latossolo Vermelho Amarelo, na escala aproximada 1: 35.000 . 
85.

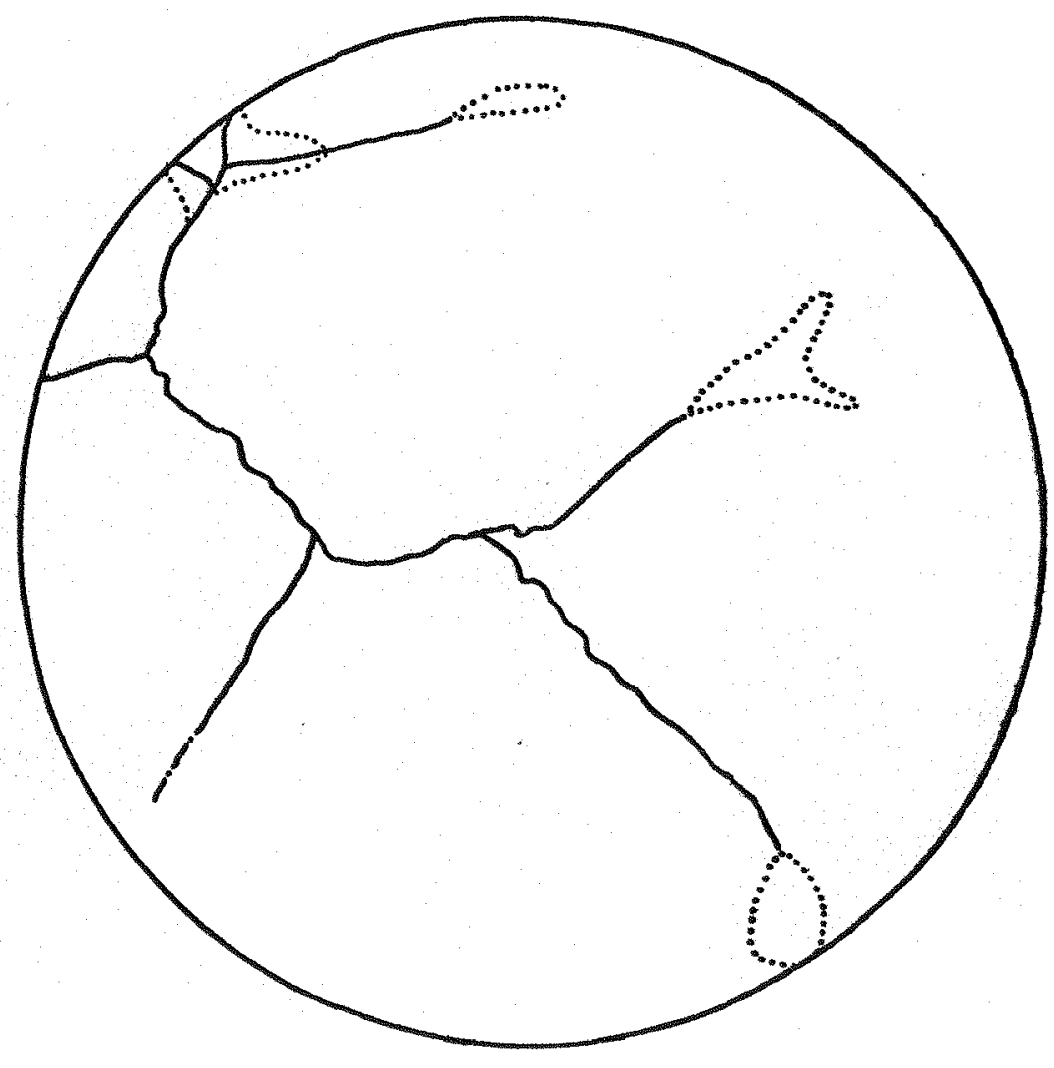

Figura 16. Anostra circular 11, representativa da unidade de solo Latossolo Vermelho Amarelo, na escala aproximada 1: 35.000 . 
86.

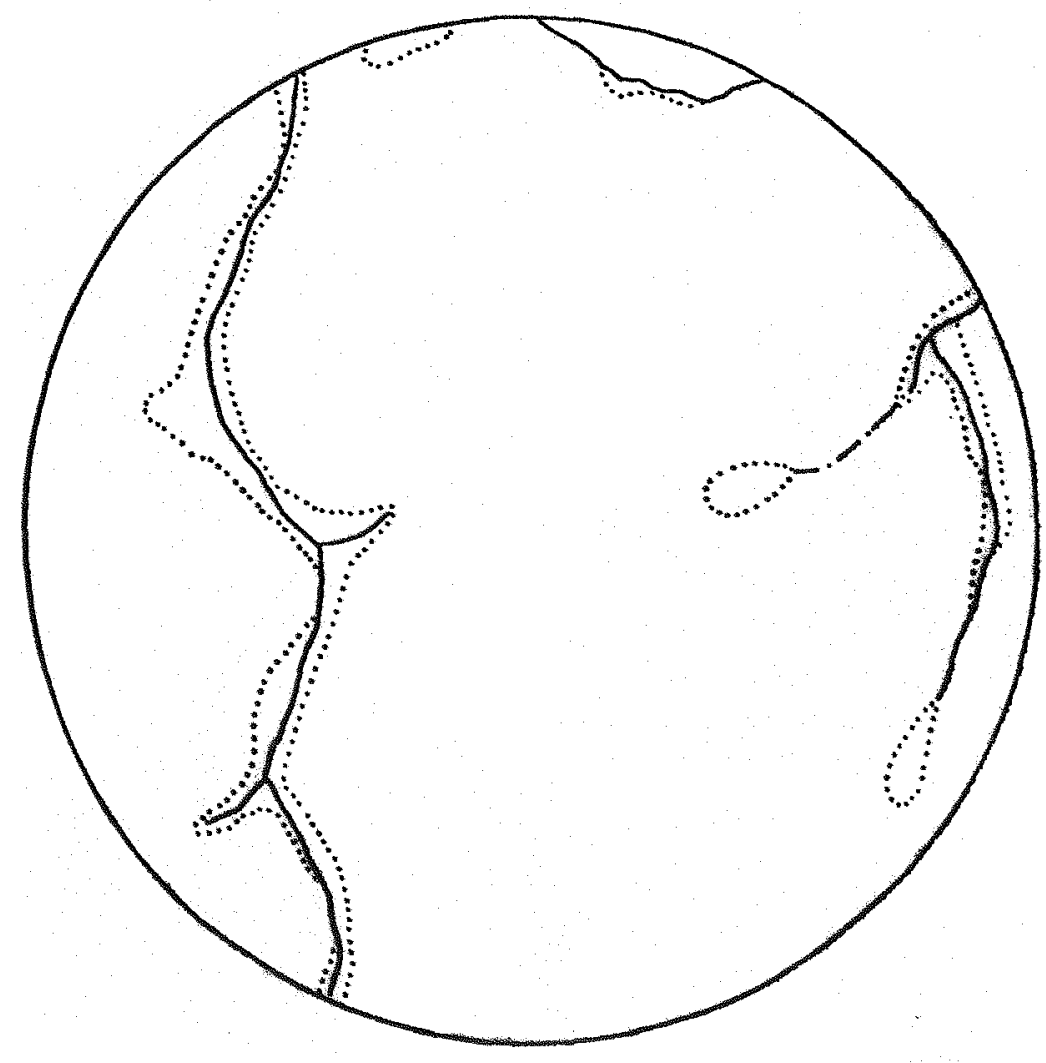

Figura 17. Amostra circular 12, representativa da unidade de solo Latossolo Vermelho Amarelo, na escala aproximada 1: 35.000 . 
87.

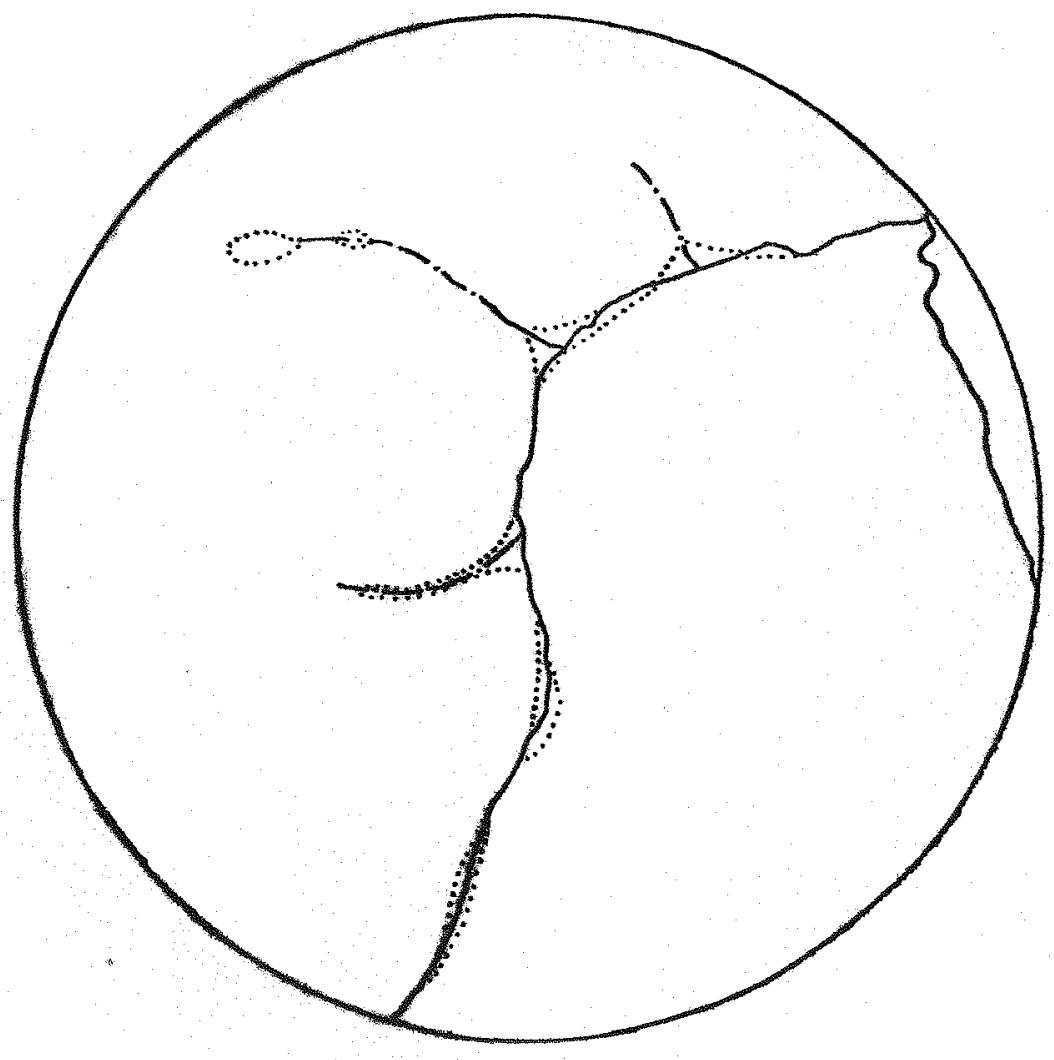

Figura 18. Amostra circular 13, representativa da unidade de solo Latossolo Vermelho Amarelo, na escala aproximada $1: 35.000$. 
88.

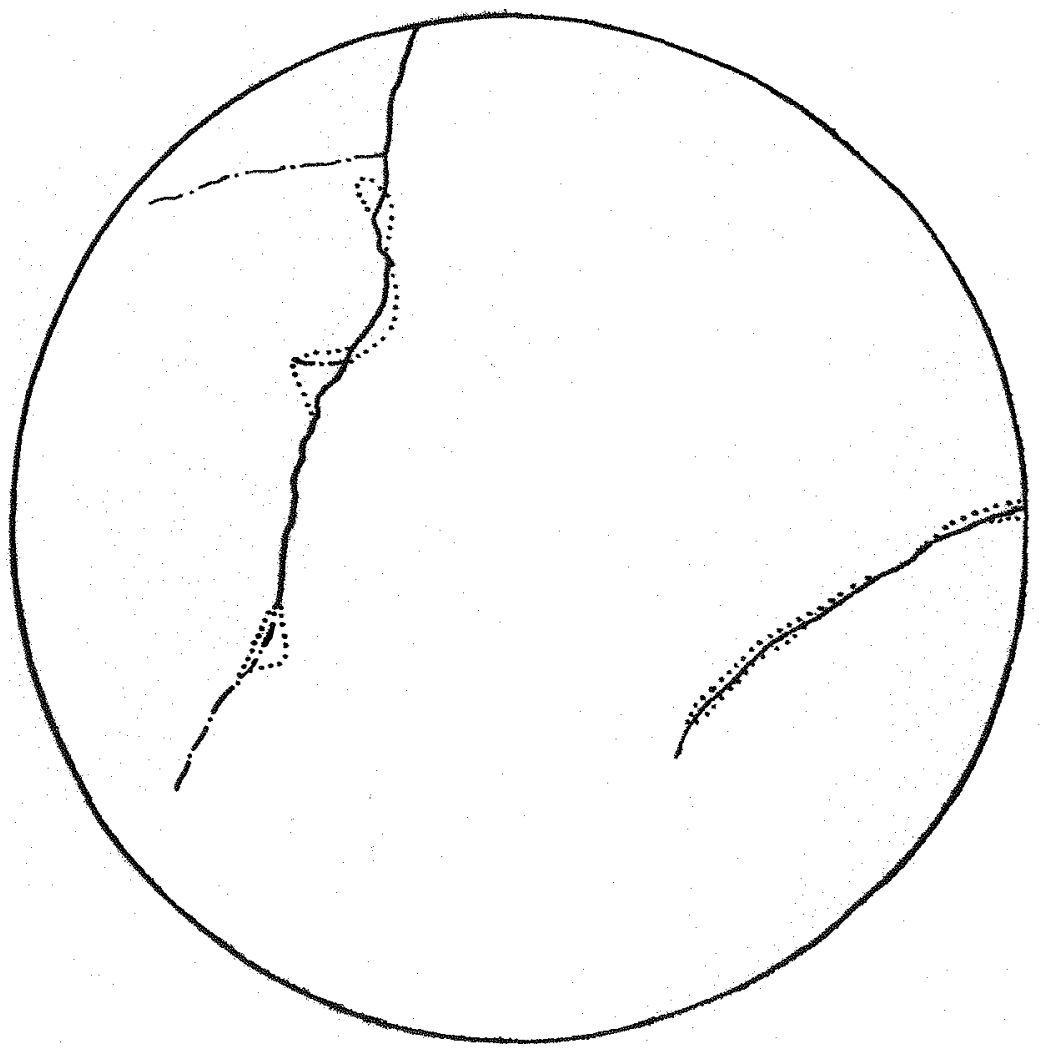

Figura 19. Amostra circular 14, representativa da unidade de solo Latossolo Vermelho Amarelo, na escala aproximada 1: 35.000 . 
89.

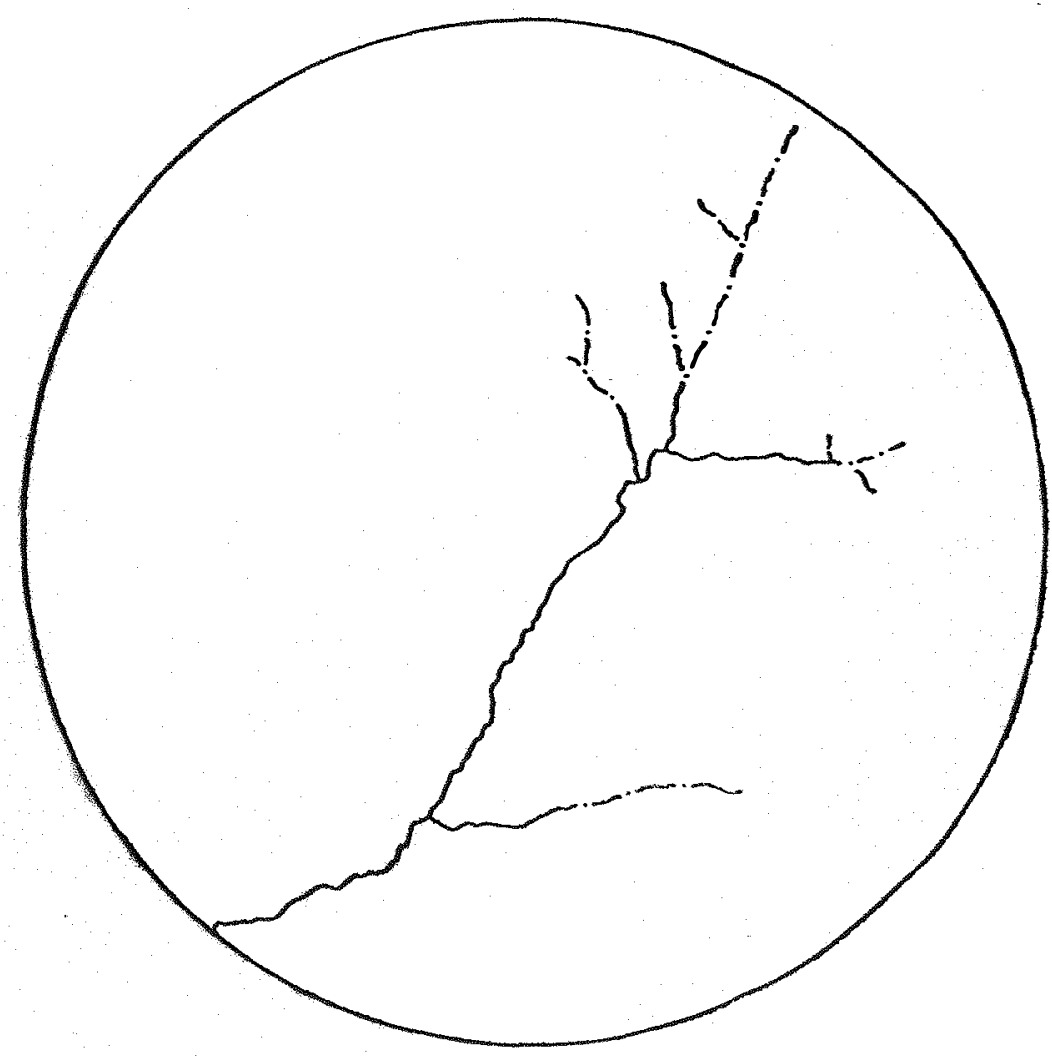

Figura 20. Amostra circular 15, representativa da unidade de solo Iatossolo Vermelho Amarelo, na escala aproximada $1: 35.000$. 


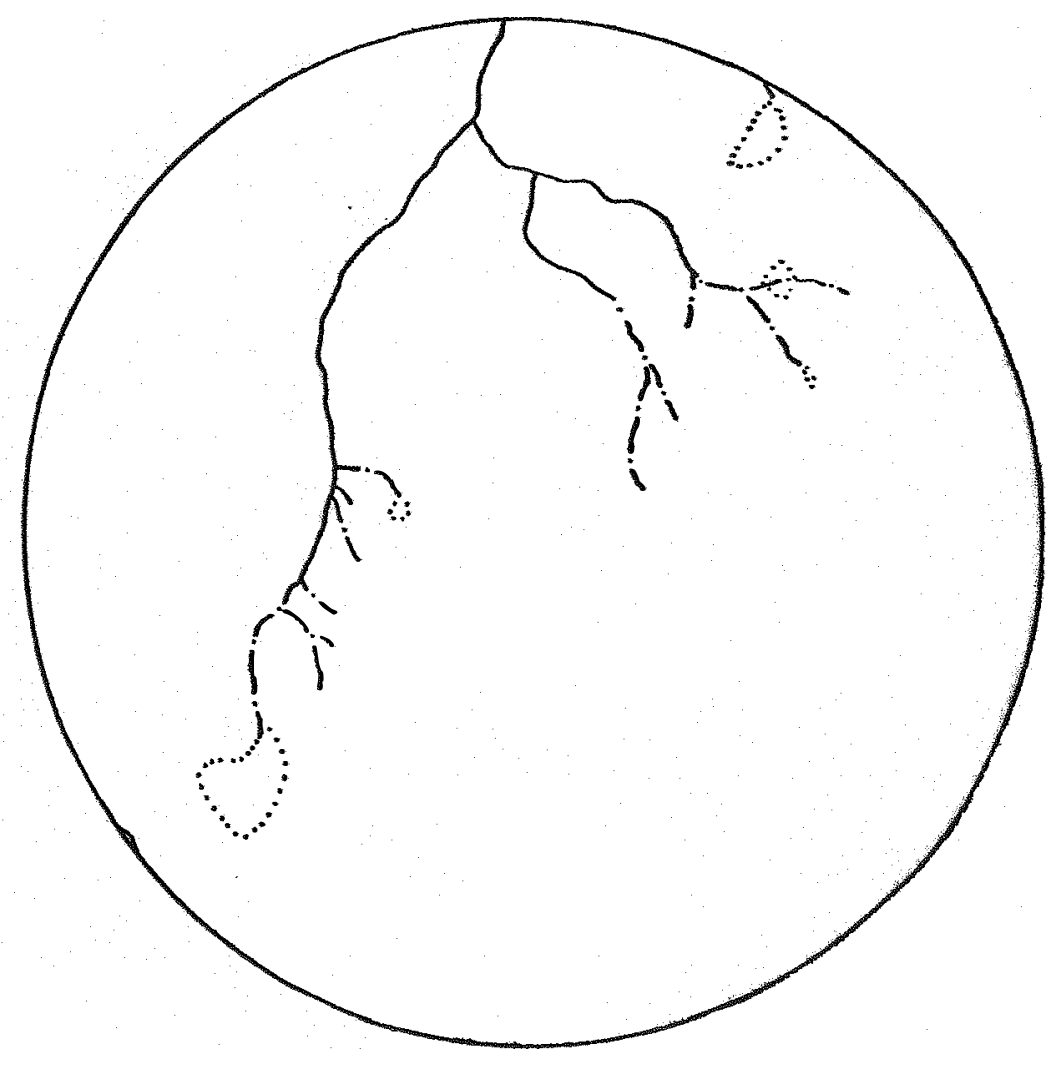

Figura 21. Amostra circular 16, representativa da unidade de solo Latossolo Roxo, na escala aproximada 1: 35.000 . 
91.

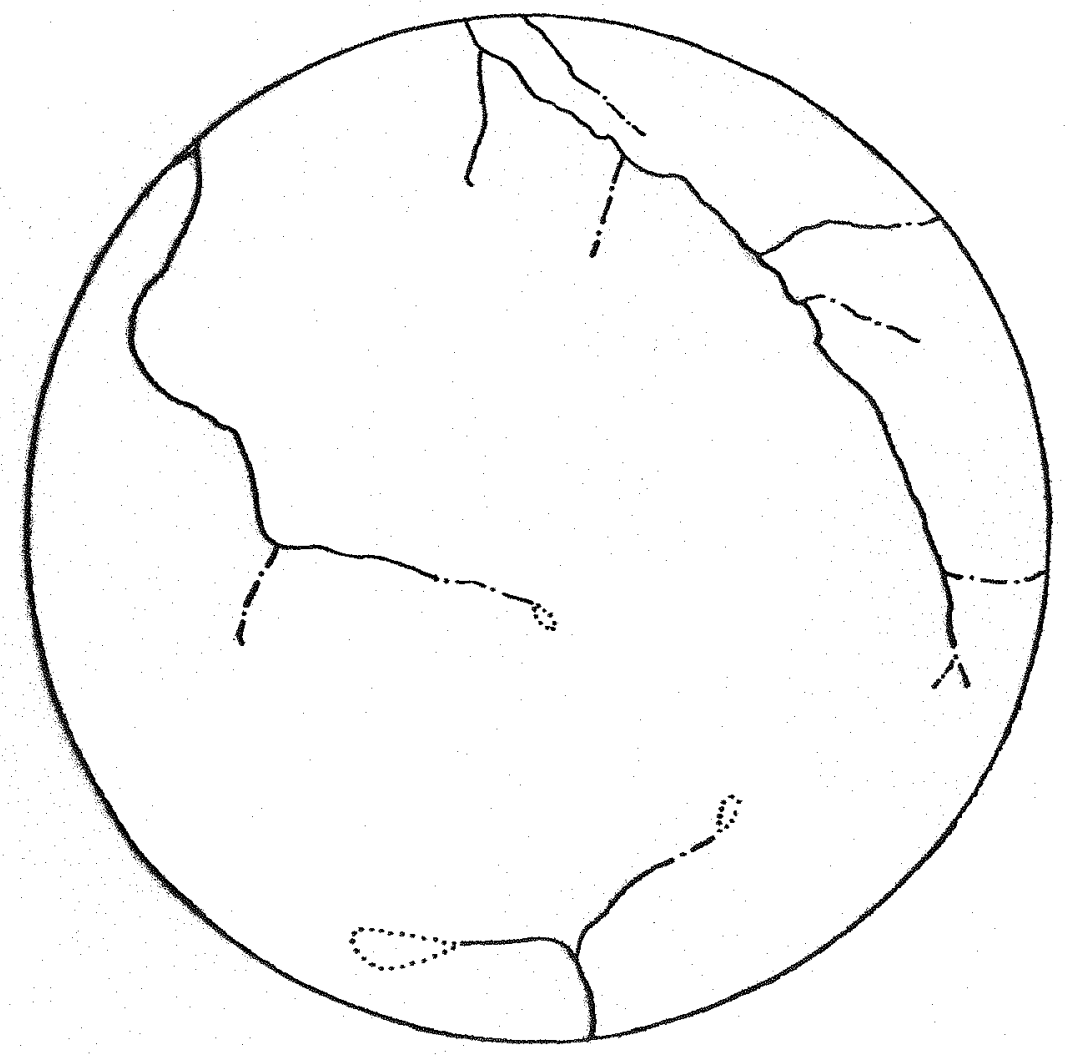

Figura 22. Amostra circular 17 , representativa da unidade de solo Latossolo Roxo, na escala aproximada 1. 35.000 . 


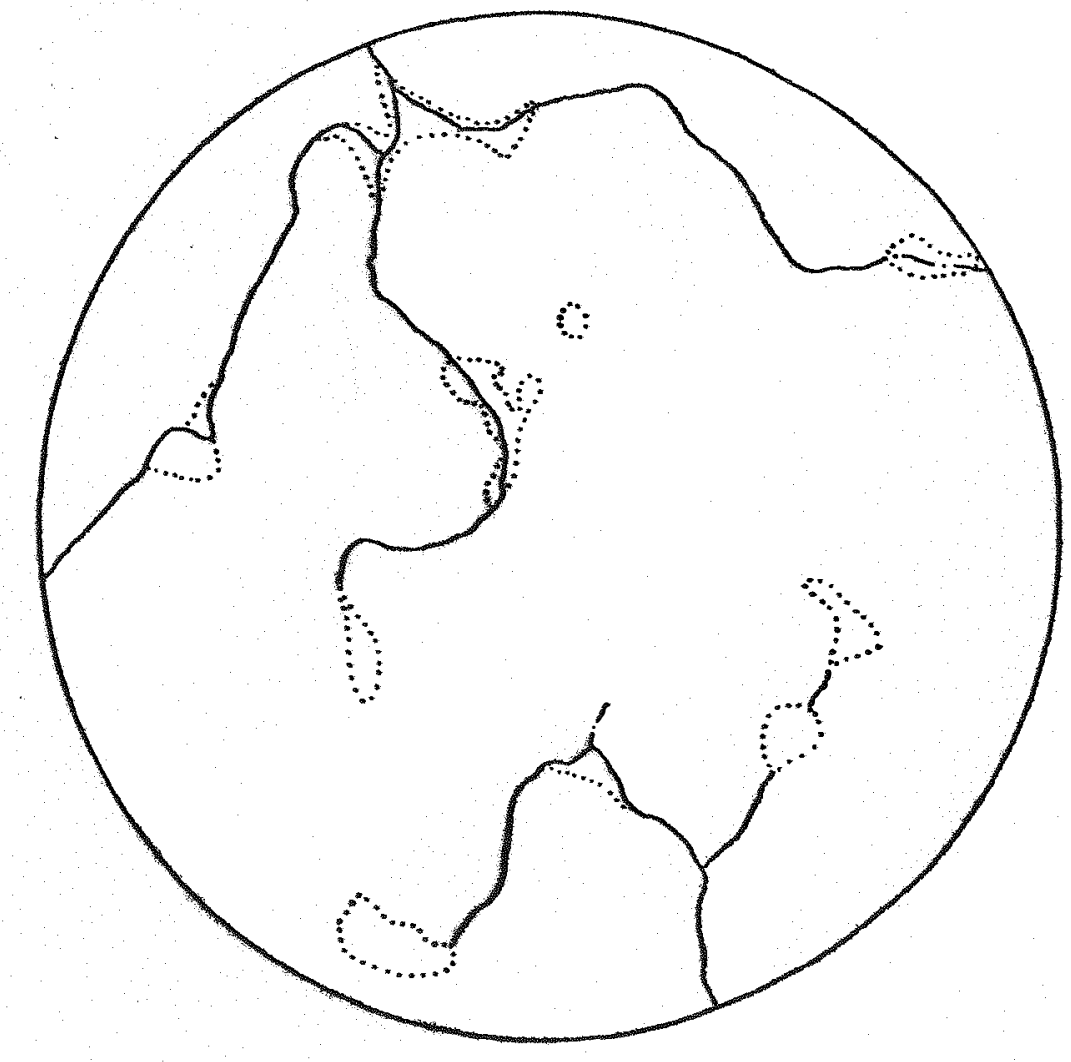

Figura 23. Amostra circular 18, representativa da unidade de solo Latossolo Roxo, na escala aproximada $1: 35.000$. 


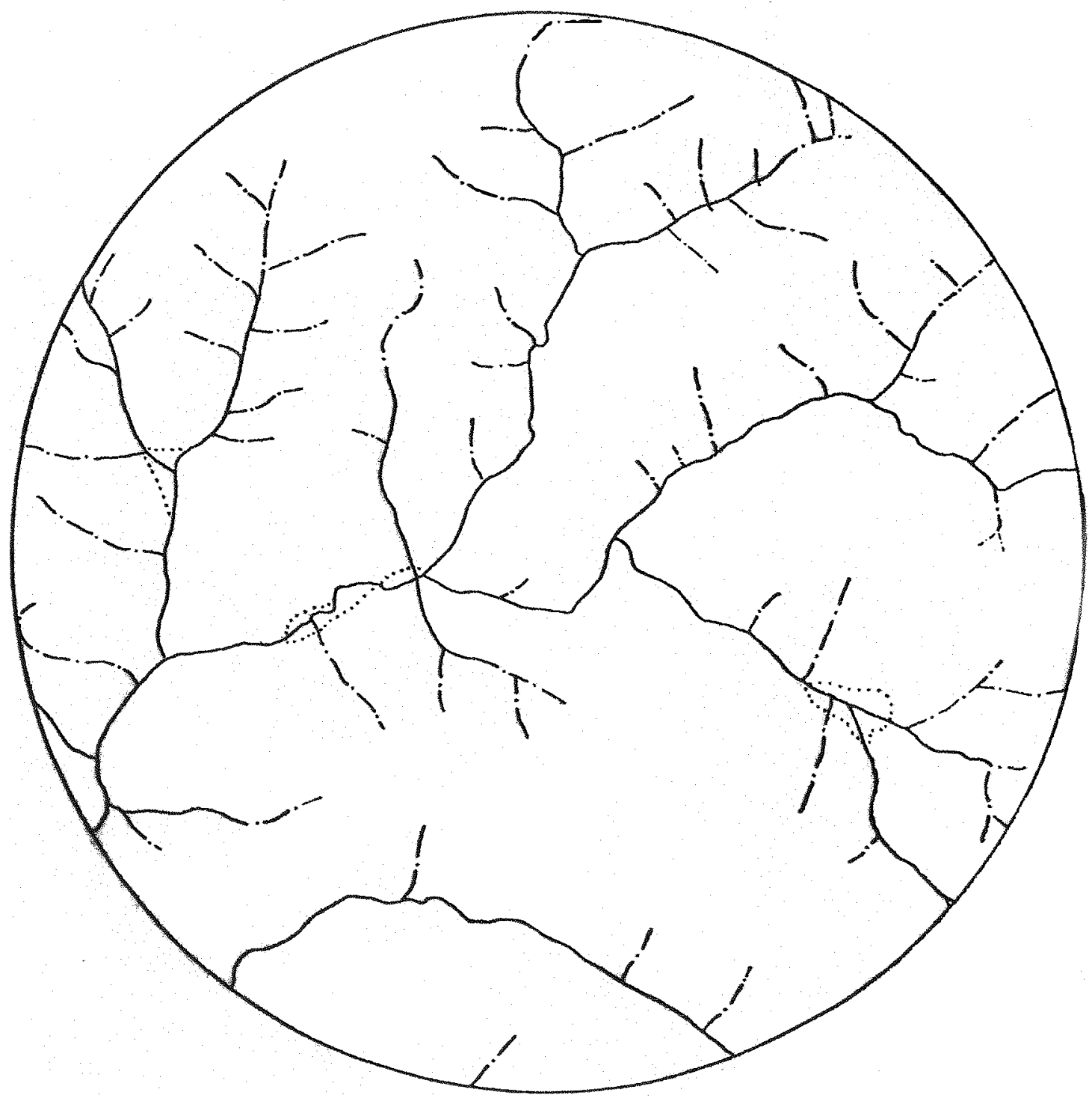

Figura 24. Amostra circular 1, representativa da unidade de solo Podzólico Vermelho Amarelo, na escala aproximada $1: 25.000$. 